\author{
UNIVERSIDADE DE SÃO PAULO \\ FACULDADE DE CIÊNCIAS FARMACÉUTICAS \\ Programa de Pós-Graduação em Fármaco e Medicamentos \\ Área de Insumos Farmacêuticos
}

\title{
Estudo farmacognóstico comparativo de Passiflora alata Curtis e Passiflora nitida Kunth (Passifloraceae). Avaliação das atividades antiúlcera e antioxidante dos seus extratos
}

\section{André Wasicky}

Dissertação para obtenção do grau de

MESTRE

Orientadora:

Profa. Dra. Edna Tomiko Myiake Kato

\section{São Paulo}




\author{
UNIVERSIDADE DE SÃO PAULO \\ FACULDADE DE CIÊNCIAS FARMACÊUTICAS \\ Programa de Pós-Graduação em Fármaco e Medicamentos \\ Área de Insumos Farmacêuticos
}

\begin{abstract}
Estudo farmacognóstico comparativo de Passiflora alata Curtis e Passiflora nitida Kunth (Passifloraceae). Avaliação das atividades antiúlcera e antioxidante dos seus extratos
\end{abstract}

André Wasicky

Dissertação para obtenção do grau de MESTRE

Orientadora:

Profa. Dra. Edna Tomiko Myiake Kato

São Paulo 
DEDALUS - Acervo - CQ

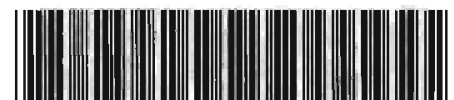

30100013147

Ficha Catalográfica

Elaborada pela Divisào de Biblioteca e

Documentaçào do Conjunto das Químicas da USP

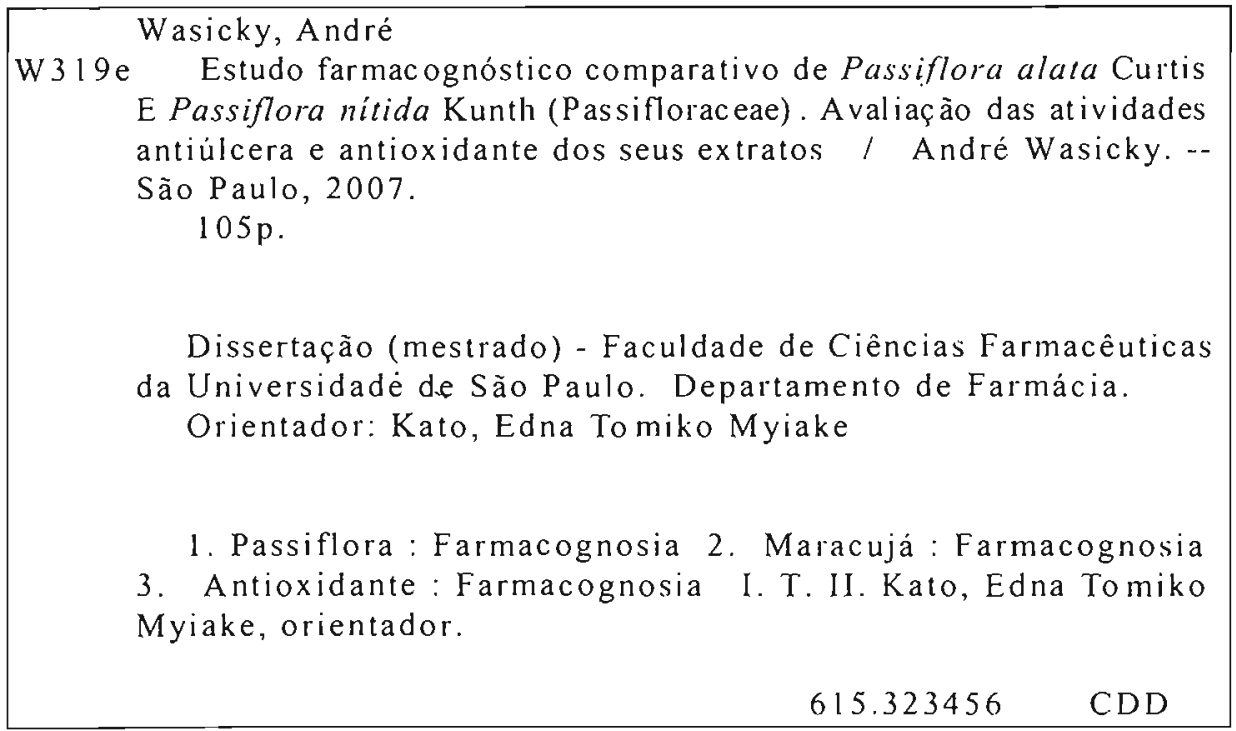


Estudo farmacognóstico comparativo de Passiflora alata Curtis e Passiflora nitida Kunth (Passifloraceae). Avaliação das atividades antiúlcera e antioxidante dos seus extratos

Comissão Julgadora

da

Dissertação para obtenção do grau de Mestre

$$
\text { Ekato }
$$

Profa. Dra. Edna Tomiko Myiake Kato

orientadora/presidente

Prof. Dr. Massayoshi Yoshida

$1^{\circ}$ examinador

Profa. Dra. Caden Souccar

$2^{\mathrm{a}}$ examinadora

São Paulo, 15 de outubro de 2007. 
“Tudo o que temos de decidir

é o que fazer com o tempo que nos é dado."

J. R. R. Tolkien 


\section{Agradecimentos}

À Profa. Dra. Edna Tomiko Myiake Kato, pela orientação, amizade e carinho, em todos os momentos.

À Profa. Dra. Elfriede Mariarıne Bacchi, pelo incentivo, apoio e presença constantes, desde o início do trabalho.

Aos professores doutores Dominique Corinne Hermine Fischer, Paulo Chanel Deodato de Freitas e Vicente de Oliveira Ferro, do Laboratório de Farmacognosia, pela amizade, apoio e companheirismo.

A todos os colegas do Laboratório de Farmacognosia, pela arnizade incondicional e pelo aprendizado mútuo, tanto intelectual como humano.

Aos outros colegas que, de uma forma ou de outra, participaram deste projeto, em especial àqueles da Faculdade de Ciências Farmacêuticas da Universidade de São Paulo.

A todos os funcionários da Faculdade de Ciências Farmacêuticas, pela ajuda e pelos bons momentos passados juntos.

À minha família, pelo incentivo e pelo apoio constantes. Isto inclui tanto os que, mais longe, sentiram a minha falta como os que, mais próximos, partilharam da realização do trabalho.

À Júlia, pelo apoio, incentivo e compreensão, além de muita paciência também, em todos os momentos.

A todos os amigos, de todos os cantos, pelos momentos de descontração, além do apoio e incentivo. Em especial aos queridos amigos da Semana da Música. Eu não vou citar nomes, vocês sabem quem vocês são. 


\section{Agradecimentos}

Aos professores doutores Laura Maria Molina Meletti, Luis Carlos Bernacci, Marcia Ortiz Mayo Marques e Marta Dias Soares Scott, do Instituto Agronômico de Campinas, pelo material vegetal utilizado neste trabalho.

Ao Antonio Carlos Franco Barbosa, do Instituto de Pesquisas Tecnológicas, pelo auxílio na obtenção dos cortes histológicos e pelos longos papos; e à Profa. Dra. Verônica Angyalossy, do Departamento de Botânica do Instituto de Biociências da USP, pela utilização do fotomicroscópio e da lupa estereoscópica.

À Cynthia Murakami e à Ludmila Raggi, alunas da Profa. Dra. Maria Claudia Marx Young, do Instituto de Botânica de São Paulo, pelo uso da câmara de luz ultravioleta, utilizada na obtenção das fotografias das placas cromatográficas.

À Profa. Dra. Silvia Berlanga de Moraes Barros, pelo uso do espectrofotômetro, durante toda a realização do trabalho. Isto se estende também a todos os alunos e funcionários do Laboratório de Patologia.

Ao Prof. Dr. Massuo Jorge Kato, do Departamento de Química Fundamental do Instituto de Química da USP, pela utilização do moinho.

Aos professores doutores Massayoshi Yoshida e Paulo Roberto Hrihorowitsch Moreno, do Departamento de Química Fundamental do Instituto de Química da USP, pela ajuda durante o desenvolvimento do trabalho.

À bibliotecária Leila Aparecida Bonadio, da Divisão de Biblioteca e Documentação do Conjunto das Químicas da USP, pela normalização das referências bibliográficas.

Ao Conselho Nacional de Desenvolvimento Científico e Tecnológico - CNPq Brasil, pelo apoio financeiro.

Meus agradecimentos. 


\section{Resumo}

Passiflora alata Curtis e $P$. nitida Kunth, espécies brasileiras, foram submetidas ao estudo farmacognóstico comparativo. $P$. alata tem sido utilizada há tempos na medicina tradicional e em preparações farmacêuticas. No estudo farmacobotânico, as folhas das duas espécies apresentaram semelhança na forma, no tamanho e na ausência de indumento. Diferem quanto ao número de glândulas peciolares. $P$. alata apresenta geralmente dois pares de glândulas e $P$. nitida, um par. Anatomicamente, as duas espécies mostraram características comuns ao gênero Passiflora: mesofilo dorsiventral; drusas no mesofilo, na nervura mediana, na região cortical, medular e floemática do caule; feixes vasculares colaterais. Embora as duas espécies apresentem nervura mediana biconvexa, a de $P$. alata evidencia as carenas pronunciadamente salientes, principalmente na face abaxial. Outro aspecto diferencial observa-se na forma do caule: em $P$. alata é quadrangular e, em $P$. nitida, arredondada. A seqüência de tecidos assemelha-se, com exceção do maior desenvolvimento de colênquima nas arestas de $P$. alata. A triagem fitoquímica evidenciou a presença de flavonóides nas duas espécies e a ausência de alcalóides em ambas, tanto na droga vegetal quanto nos extratos. Formação de espuma persistente foi observada com a droga vegetal preparada com $P$. alata. A hemólise foi observada com a droga e o extrato desta espécie. Os flavonóides foram quantificados como $0,42 \% \pm 0,01 \mathrm{em} P$. alata e $0,10 \% \pm 0,01 \mathrm{em} P$. nitida. No ensaio da atividade antioxidante, a $\mathrm{EC}_{50}$ de $P$. alata foi de $1061,2 \pm 8,5 \mu \mathrm{g} / \mathrm{mL}$ e a de $P$. nitida $128,0 \pm 0,9 \mu \mathrm{g} / \mathrm{mL}$, no ensaio do DPPH, e de $1076 \pm 85 \mu \mathrm{mol}$ de Trolox/g de extrato e de $1985 \pm 104 \mu \mathrm{mol}$ de Trolox/g de extrato no ensaio de ORAC, respectivamente. No ensaio de atividade antiúlcera aguda $P$. alata exibiu, na área total de lesão (ATL), proteção contra as lesões gástricas de $100 \%, P$. nitida de $84 \%$ e lansoprazol, o controle positivo, de $76 \%$. Quanto à área relativa de lesão (ARL), $P$. alata exibiu proteção contra as lesões de $99,45 \% ; P$. nítida, de $82,27 \%$ e lansoprazol, de $81,44 \%$, no ensaio de lesão gástrica induzida por etanol/ $\mathrm{HCl}$ com $300 \mathrm{mmol} / \mathrm{L}$ de $\mathrm{HCl}$ e extratos na dose de $400 \mathrm{mg} / \mathrm{kg}$. As doses de 100, 200 e 400 $\mathrm{mg} / \mathrm{kg}$ dos extratos foram testadas nas mesmas condições com $150 \mathrm{mmol} / \mathrm{L}$ de $\mathrm{HCl}$. $P$. alata apresentou, na ATL, $100 \%$ de proteção contra as lesões gástricas nas três concentrações e lansoprazol, de $75 \%$. Na ARL, $P$. alata exibiu $100 \%$ de proteção e 
lansoprazol, de $76,92 \%$. P. nitida apresentou, na ATL, proteção contra as lesões gástricas de $25 \%, 74 \%$ e $94 \%$ nas três concentrações, respectivamente e, lansoprazol, de $80 \%$. Na ARL, P. nitida exibiu $27,40 \%, 74,00 \%$ e $91,78 \%$ de proteção, respectivamente e lansoprazol, de 78,08\%. Baseando-se neste estudo é possivel distinguir as duas espécies através de características morfoanatômicas das folhas e dos caules e, através do perfil cromatográfico. Ambas as espécies apresentaram atividade antiúlcera promissora.

Palavras-chave: Passiflora alata; Passiflora nitida; flavonóides; antioxidante; antiúlcera. 
Comparative pharmacognostic study of Passiflora alata Curtis and $P$. nitida Kunth (Passifloraceae). Evaluation of antiulcer and antioxidant activities of its extracts

Abstract

Passiflora alata Curtis and P. nitida Kunth, Brazilian species, were selected for the comparative pharmacognostic study. $P$. alata has been used for a long time in folk medicine and pharmaceutical preparations. In the pharmacobotanic study, leaves from both species showed similarities in shape, size and in the absence of indumenta. They differ by the number of petiolar glands. $P$. alata presents generally two pairs of glands and $P$. nitida, one pair. Anatomically, both species showed common characteristics to the Passiflora genera: dorsiventral mesophyll; druses in the mesophyll, midrib, cortex, medulla and phloem; collateral vascular bundles. Both species' midrib presented a biconvex shape, but $P$. alata's was prominently $V$ shaped, notably in the abaxial surface. Another differential aspect was observed in the stem shape: $P$. alata was quadrangular and $P$. nitida was rounded. The tissues sequence presented similarity, with exception to larger collenchyma development in $P$. alata's edges. The phytochemical screening showed presence of flavonoids and absence of alkaloids in both species, in the crude drug and extracts. Formation of persistent foam was observed with the crude drug of $P$. alata. Hemolisis was observed with the crude drug and extract of this species. Flavonoids were quantified as $0.42 \% \pm 0.01$ in $P$. alata and $0.10 \% \pm 0.01$ in $P$. nitida. In the antioxidant activity assay, the $\mathrm{EC}_{50}$ of $P$. alata was $1061.2 \pm 8.5 \mu \mathrm{g} / \mathrm{mL}$ and of $P$. nitida, $128.0 \pm 0.9$ $\mu \mathrm{g} / \mathrm{mL}$, in the DPPH assay, and $1076 \pm 85 \mu \mathrm{mol}$ Trolox/g extract and $1985 \pm 104$ $\mu \mathrm{mol}$ Trolox/g extract in the ORAC assay, respectively. In the antiulcer activity assay $P$. alata showed, in total lesion area (TLA), protection against gastric lesions of $100 \%$, P. nitida $84 \%$ and lansoprazole, the positive control, $76 \%$. In relative lesion area (RLA), $P$. alata showed protection against lesions of $99.45 \%$, $P$. nitida $82.27 \%$ and lansoprazole $81.44 \%$, in the $\mathrm{HCl} /$ ethanol-induced gastric lesion assay, with $\mathrm{HCl}$ $300 \mathrm{mmol} / \mathrm{L}$ and extracts at doses of $400 \mathrm{mg} / \mathrm{kg}$. Doses of $100,200 \mathrm{e} 400 \mathrm{mg} / \mathrm{kg}$ of extracts were tested in the same conditions with $\mathrm{HCl} 150 \mathrm{mmol} / \mathrm{L}$. $P$. alata showed, in TLA, protection against gastric lesions of $100 \%$ in the three concentrations and 
lansoprazole $75 \%$. In RLA, P. alata showed $100 \%$ of protection and lansoprazole $76.92 \%$. P. nitida showed, in TLA, protection against gastric lesions of $25 \%, 74 \%$ and $94 \%$ in the three concentrations, respectively and lansoprazole $80 \%$. In RLA, $P$. nitida showed $27.40 \%, 74.00 \%$ and $91.78 \%$ of protection, respectively and lansoprazole $78.08 \%$. Based upon this study it is possible to distinguish both species by leaf and stem morphoanatomic characters and by chromatographic profile. Both species presented promising antiulcer activity.

Keywords: Passiflora alata; Passiflora nitida; flavonoids; antioxidant; antiulcer. 


\section{Lista de ilustraçōes}

Figura 1. Alcalóides $\beta$-carbolínicos encontrados em espécies de Passiflora L.

Figura 2. Flavonóides encontrados em espécies de Passiflora L. .......... 12

Figura 3. Glicosídeos cianogênicos do grupo 1 encontrados em espécies de Passiflora L.

Figura 4. Glicosídeos cianogênicos do grupo 2 encontrados em espécies de Passiflora L.

Figura 5. Glicosídeos cianogênicos dos grupos 3 e 4 encontrados em espécies de Passiflora L.

Figura 6. Saponinas encontradas em espécies de Passiflora L. ............. 27

Figura 7. Maltol, encontrado na espécie Passiflora incarnata L. ............. 31

Figura 8. Ramos floridos de Passiflora alata Curtis e P. nitida Kunth ...... 36

Figura 9. Esquema de obtenção das drogas vegetais (Passiflora alata Curtis e $P$. nitida Kunth) e estudos subseqüentes

Figura 10. Esquema de redução do radical 2,2-difenil-1-picril hidrazila (DPPH) por compostos fenólicos (ROH)

Figura 11. Passiflora alata Curtis

Figura 12. Folha de Passiflora alata Curtis

Figura 13. Caule de Passiflora alata Curtis

Figura 14. Passiflora nitida Kunth

Figura 15. Folha de Passiflora nitida Kunth

Figura 16. Caule de Passiflora nitida Kunth

Figura 17. Cromatograma em camada delgada comparativo de Passiflora alata Curtis e P. nitida Kunth

Figura 18. Atividade antiúlcera do extrato liofilizado de Passiflora alata Curtis. Indução de úlcera por etanol e ácido clorídrico (150 $\mathrm{mmol} / \mathrm{L}$ de ácido em $60 \% \mathrm{v} / \mathrm{v}$ de etanol) 


\section{Lista de ilustrações}

Figura 19. Atividade antiúlcera do extrato liofilizado de Passiflora alata Curtis. Indução de úlcera por etanol e ácido clorídrico (150 $\mathrm{mmol} / \mathrm{L}$ de ácido em $60 \% \mathrm{v} / \mathrm{v}$ de etanol). Área total de lesão ...

Figura 20. Atividade antiúlcera do extrato liofilizado de Passiflora alata Curtis. Indução de úlcera por etanol e ácido clorídrico (150 $\mathrm{mmol} / \mathrm{L}$ de ácido em $60 \% \mathrm{v} / \mathrm{v}$ de etanol). Área relativa de lesão

Figura 21. Atividade antiúlcera do extrato liofilizado de Passiflora nitida Kunth. Indução de úlcera por etanol e ácido clorídrico (150 $\mathrm{mmol} / \mathrm{L}$ de ácido em $60 \% \mathrm{v} / \mathrm{v}$ de etanol)

Figura 22. Atividade antiúlcera do extrato liofilizado de Passiflora nitida Kunth. Indução de úlcera por etanol e ácido clorídrico (150 $\mathrm{mmol} / \mathrm{L}$ de ácido em $60 \% \mathrm{v} / \mathrm{v}$ de etanol). Área total de lesão ...

Figura 23. Atividade antiúlcera do extrato liofilizado de Passiflora nitida Kunth. Indução de úlcera por etanol e ácido cloridrico (150 $\mathrm{mmol} / \mathrm{L}$ de ácido em $60 \% \mathrm{v} / \mathrm{v}$ de etanol). Área relativa de lesão

Figura 24. Atividade antiúlcera dos extratos liofilizados de Passiflora alata Curtis e de $P$. nitida Kunth. Indução de úlcera por etanol e ácido clorídrico (300 $\mathrm{mmol} / \mathrm{L}$ de ácido $\mathrm{em} 60 \% \mathrm{v} / \mathrm{v}$ de etanol)

Figura 25. Atividade antiúlcera dos extratos liofilizados de Passiflora alata Curtis e de $P$. nitida Kunth. Indução de úlcera por etanol e ácido cloridrico $(300 \mathrm{mmol} / \mathrm{L}$ de ácido em $60 \% \mathrm{v} / \mathrm{v}$ de etanol). Área total de lesão

Figura 26. Atividade antiúlcera dos extratos liofilizados de Passiflora alata Curtis e de $P$. nitida Kunth. Indução de úlcera por etanol e ácido clorídrico $(300 \mathrm{mmol} / \mathrm{L}$ de ácido em $60 \% \mathrm{v} / \mathrm{v}$ de etanol). Área relativa de lesão 


\section{Lista de tabelas}

Tabela 1. Alcalóides $\beta$-carbolínicos encontrados em espécies de Passiflora L.

Tabela 2. Flavonóides encontrados em espécies de Passiflora L.

Tabela 3. Glicosídeos cianogênicos encontrados em espécies de Passiflora L.

Tabela 4. Saponinas encontradas em espécies de Passiflora L.

Tabela 5. Avaliação da presença de saponinas nas drogas vegetais e nos extratos liofilizados de Passiflora alata Curtis e $P$. nitida Kunth ..

Tabela 6. Teor de flavonóides nas drogas vegetais e nos extratos liofilizados de Passiflora alata Curtis e $P$. nitida Kunth

Tabela 7. Atividade antiúlcera do extrato liofilizado de Passiflora alata Curtis. Indução de úlcera por etanol e ácido clorídrico (150 $\mathrm{mmol} / \mathrm{L}$ de ácido em $60 \% \mathrm{v} / \mathrm{v}$ de etanol)

Tabela 8. Atividade antiúlcera do extrato liofilizado de Passiflora nitida Kunth. Indução de úlcera por etanol e ácido clorídrico (150 $\mathrm{m}$ mol/L de ácido em $60 \% \mathrm{v} / \mathrm{v}$ de etanol)

Tabela 9. Atividade antiúlcera dos extratos liofilizados de Passiflora alata Curtis e $P$. nitida Kunth. Indução de úlcera por etanol e ácido clorídrico (300 $\mathrm{mmol} / \mathrm{L}$ de ácido em $60 \% \mathrm{v} / \mathrm{v}$ de etanol) 


\section{Sumário}

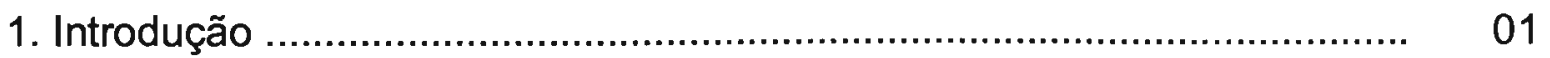

2. Revisão de literatura ........................................................................ 03

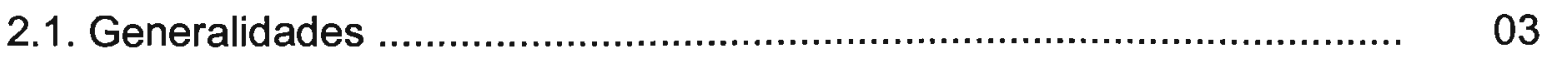

2.2. Aspectos químicos ...................................................................... 04

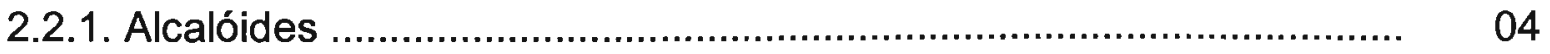

2.2.2. Flavonóides ............................................................................ 10

2.2.3. Glicosídeos cianogênicos ............................................................ 18

2.2.4. Saponinas ........................................................................ 25

2.3. Atividades farmacológicas de espécies de Passiflora L. ...................... 28

2.4. Passiflora alata Curtis ..................................................................... 33

2.5. Passiflora nitida Kunth .................................................................. 36

3. Objetivos ................................................................................ 37

4. Material e métodos …................................................................... 38

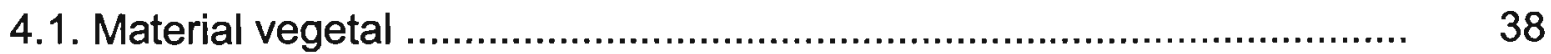

4.2. Estudo farmacobotânico .................................................................. 39

4.3. Preparo do extrato hidroetanólico liofilizado .......................................... 40

4.4. Triagem fitoquímica .................................................................. 40

4.4.1. Flavonóides .......................................................................... 40

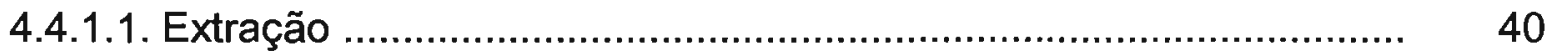

4.4.1.2. Sistema cromatográfico .......................................................... 41

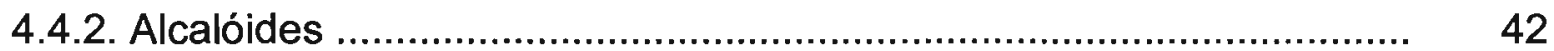

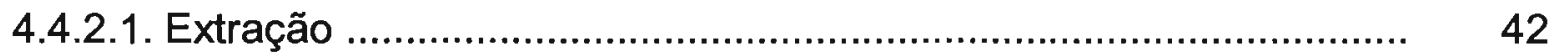

4.4.2.2. Sistema cromatográfico ........................................................ 42

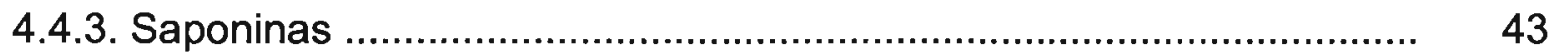

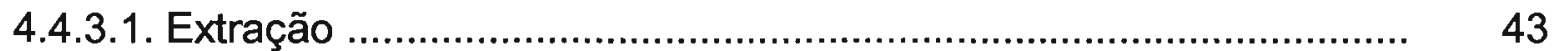

4.4.3.2. Índice de espuma ................................................................. 43

4.4.3.3. Índice de hemólise .................................................................... 44

4.5. Flavonóides totais ........................................................................ 45

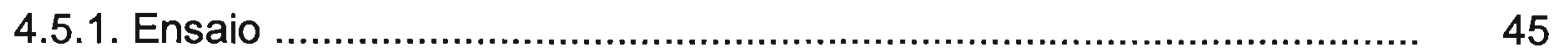

4.5.1.1. Solução A ....................................................................... 45

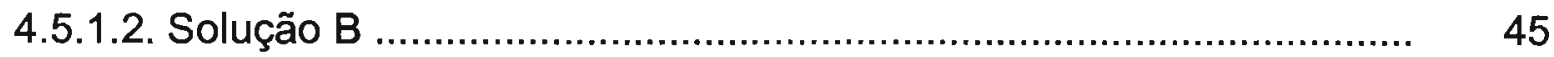

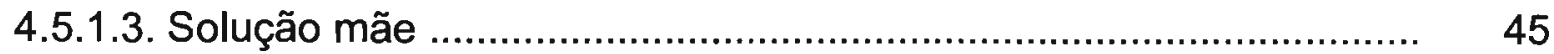




\section{Sumário}

4.5.1.4. Solução teste ................................................................. 46

4.5.1.5. Solução de compensação ....................................................... 46

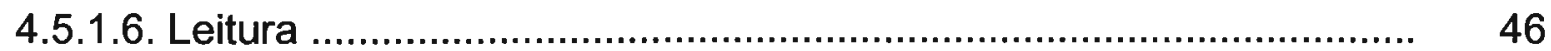

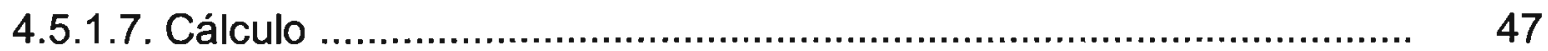

4.6. Atividade antioxidante ............................................................... 47

4.6.1. Ensaio do DPPH .................................................................... 47

4.6.1.1. Solução mãe ..................................................................... 48

4.6.1.2. Solução de rutina ................................................................. 48

4.6.1.3. Solução teste ...................................................................... 49

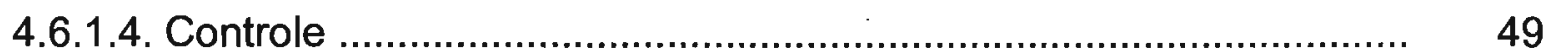

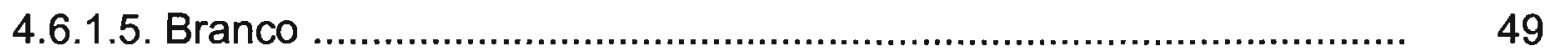

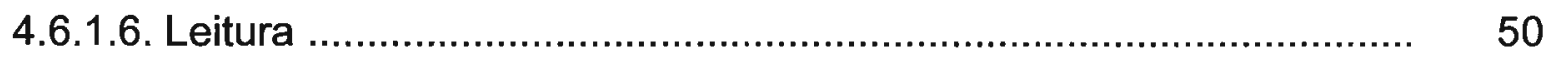

4.6.1.7. Cálculo .............................................................................. 50

4.6.2. Ensaio de ORAC ..................................................................... 51

4.6.2.1. Reagentes ....................................................................... 51

4.6.2.2. Ensaio ............................................................................. 51

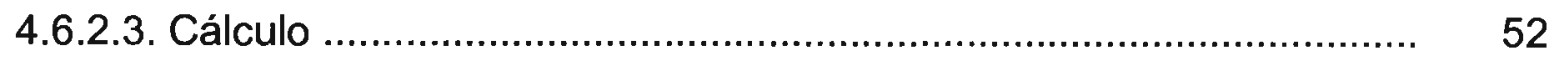

4.7. Atividade antiúlcera aguda ..................................................... 53

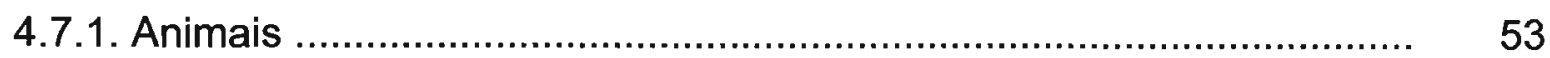

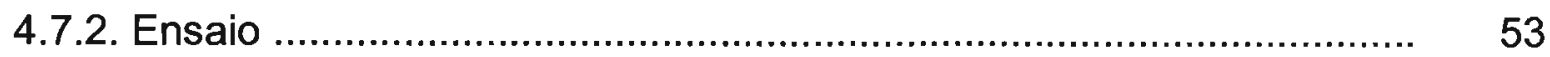

4.7.2.1. Tratamento com extrato hidroetanólico liofilizado ......................... 53

4.7.2.2. Procedimento para produção de lesão gástrica ........................... 54

4.7.2.3. Cálculo ........................................................................... 54

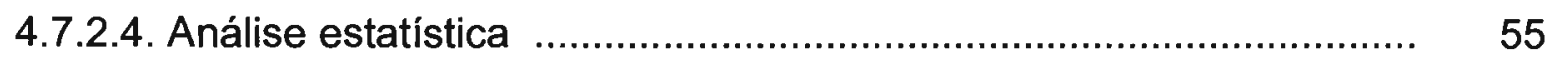

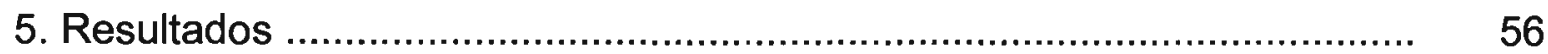

5.1. Estudo farmacobotânico ............................................................ 56

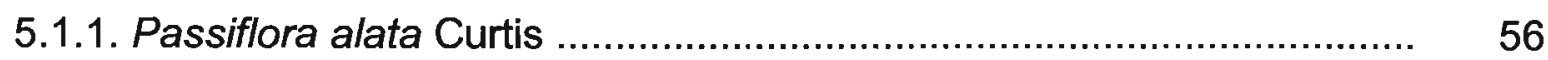

5.1.1.1. Descrição macroscópica ........................................................ 56

5.1.1.2. Descrição microscópica ....................................................... 57

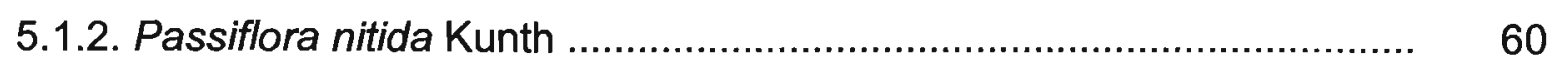

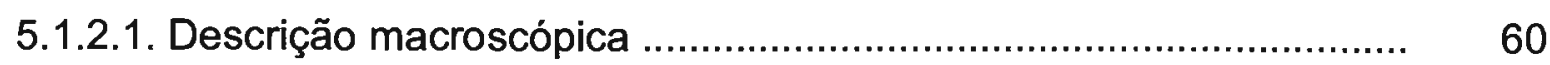

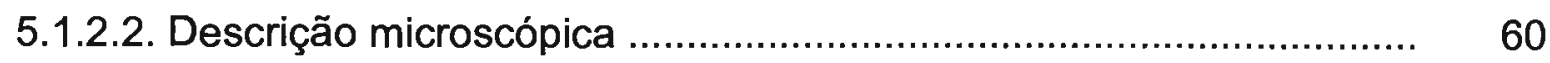




\section{Sumário}

5.2. Triagem fitoquímica .......................................................... 64

5.2.1. Flavonóides ........................................................................ 64

5.2.2. Saponinas ..................................................................... 65

5.3. Flavonóides totais .............................................................. 65

5.4. Atividade antioxidante ............................................................. 66

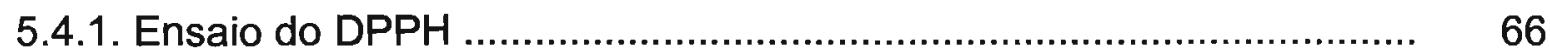

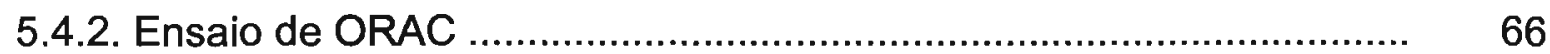

5.5. Atividade antiúlcera aguda ..................................................... 68

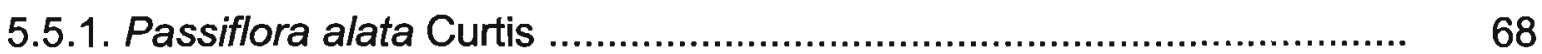

5.5.2. Passiflora nitida Kunth ......................................................... 72

5.5.3. Passiflora alata Curtis e Passiflora nitida Kunth ............................. 75

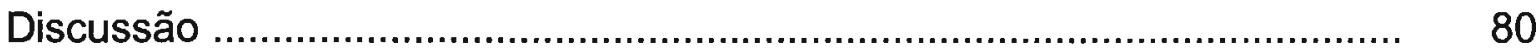

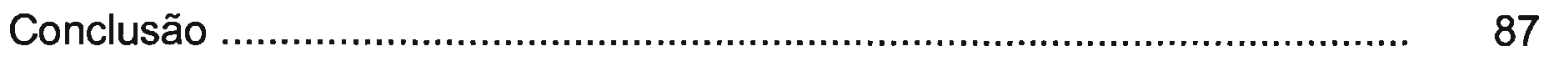

Referências bibliográficas ............................................................ 88 


\section{Introdução}

O uso de produtos naturais, especialmente aqueles derivados de plantas medicinais, é uma forma tradicional de promover alívio para diversas doenças. O interesse científico nas plantas medicinais aumentou de forma considerável durante a última década e esforços têm sido realizados para entender e explicar os efeitos benéficos de diversas substâncias ou extratos vegetais (MAHMMOUD, 2007).

Um dos atrativos das plantas medicinais é a diversidade estrutural de compostos que se constituem em fontes potenciais de novas moléculas bioativas (McGUIRE, 2001; PINK et al., 2005).

Ao longo dos anos, a pesquisa de produtos naturais tem contribuído enormemente para o desenvolvimento de fármacos utilizados correntemente na medicina moderna (MEDEIROS et al., 2007). Como exemplos podem-se citar a digoxina (Digitalis lanata Ehrhart.), a morfina (Papaver somniferum L.) e o taxol (Taxus brevifolia Nutt.), entre outros (McGUIRE, 2001; PINK et al., 2005).

Trinta por cento das substâncias identificadas como promissoras para o tratamento de doenças, entre 1981 e 2002, são produtos naturais ou derivados destes. E, além destes, $20 \%$ das novas moléculas são produtos sintetizados que mimetizam as estruturas encontradas na natureza (NEWMAN; CRAGG; SNADER, 2003; BALUNAS; KINGHORN, 2005).

A pesquisa de fármacos a partir de plantas inicia-se com a comprovação da atividade farmacológica de uma espécie a partir dos dados de uso tradicional. E a presença de atividade direciona o processo de isolamento dos compostos ativos, visando o estudo dos mecanismos de ação das substâncias (BALUNAS; KINGHORN, 2005).

Hypericum perforatum $\mathrm{L}$. é um exemplo deste processo. Esta planta medicinal tem sido utilizada tradicionalmente no tratamento da depressão, sobretudo nos Estados Unidos da América do Norte. No entanto, apenas nos últimos anos o mecanismo molecular de ação de seus constituintes químicos tem sido estudado (CHOUDHURI, VALERIO JR., 2005). 
Assim, tanto a comprovação da atividade antidepressiva de $H$. perforatum como o estudo de possiveis interações farmacológicas ou mesmo efeitos toxicológicos dependem da investigação dos mecanismos de ação de seus constituintes, o que é de vital importância na comprovação científica da utilização de qualquer espécie a partir do uso tradicional (CHOUDHURI, VALERIO JR., 2005).

O projeto temático no qual esta dissertação encontra-se incluída, trata da caracterização farmacognóstica das espécies de Passiflora, estabelecendo parâmetros para o controle de qualidade das drogas vegetais e dos extratos preparados com espécies cultivadas no país. O gênero foi escolhido em razão da variabilidade de resultados químicos e farmacológicos encontrados na literatura (MALUF et al., 1991; DHAWAN; DHAWAN; SHARMA, 2004), que faz paralelo à diversidade do gênero.

O gênero Passiflora foi descrito pela primeira vez por Nicolau Monardis em 1569 (SOUZA, 1997). No Brasil, as espécies do gênero Passiflora são conhecidas pela população como "maracujá". A palavra de origem tupi guarani, que significa comida feita em cuia, numa alusão aos frutos do vegetal, é empregada na designação de diversas espécies do gênero, conhecidas por seu valor econômico e suas propriedades medicinais (MORAES, 1995, SOUZA; ORTEGA, 1997, DERMARDEROSIAN; BEUTLER, 2002; PLOTZE et al., 2005).

A definição das espécies tema da dissertação ficaram subordinadas à importância das espécies na medicina popular e à disponibilidade de material vegetal cultivado no Instituto Agronômico de Campinas. Assim, Passiflora alata Curtis, espécie inscrita nas três primeiras edições da Farmacopéia Brasileira e Passiflora nitida Kunth, espécie morfologicamente semelhante à primeira, mas com maior resistência a pragas, foram selecionadas. Destaca-se a proximidade morfológica das duas espécies que pode levar a confusões, adulterações ou fraudes, comuns no mercado de drogas vegetais (PLOTZE et al., 2005). 


\section{Revisão de literatura}

\subsection{Generalidades}

A familia Passifloraceae compreende 19 gêneros e cerca de 530 espécies (BERNACCI, 2003) com distribuição, principalmente, nas Américas e na África (BARROSO, 1978; JOLY, 1985; BERNACCI, 2003). Esta familia caracteriza-se pela presença de flavonóides, alcalóides e glicosídeos cianogênicos (BOKSTALLER; SCHMIDT, 1997; ABOURASHED; VANDERPLANCK; KHAN, 2003). Os flavonóides têm merecido destaque na utilização como marcadores na análise de medicamentos fitoterápicos. Como exemplo, a Farmacopéia Européia (EUROPEAN PHARMACOPOEIA, 2005) utiliza a quantificação de flavonóides $C$-glicosídeos no controle de qualidade de $P$. incarnata $\mathrm{L}$.

O gênero Passiflora, predominante na familia, distribui-se pelas áreas tropicais e subtropicais, com marcada concentração de espécies na América Central e norte da América do Sul (DERMARDEROSIAN; BEUTLER, 2002; PLOTZE et al., 2005). É representado por aproximadamente 400 espécies, sendo que 120 ocorrem somente no Brasil e 38 apenas no Estado de São Paulo (BERNACCI, 2003).

Suas espécies apresentam hábito escandente, folhas alternas, estípulas, gavinhas, nectários extraflorais e corona composta de uma ou várias séries de filamentos ou lobos no ápice do hipanto (JUDD et al., 1999; PLOTZE et al., 2005).

O uso de Passiflora decorreu de suas propriedades sedativas, tendo início na Europa, no século XVII (FREITAS, 1985). Encontram-se ainda relatos na literatura sobre suas propriedades antiespasmódicas, uso em distúrbios gastrintestinais (DUKE, 2002; MAHADY et al., 2005), insônia, histeria (KRUGER, 1992; DELLA LOGGIA, 1993; GARCIA, 2000; PDR, 2000), atividade hipnótica suave (SCAVONE; PANIZZA, 1978), hipotensora (GRIEVE; LEYEL, 1994) e miorrelaxante (GARCIA, 2000). São também indicadas em casos de asma, diarréia, convulsão infantil (BALBACHAS, 1957) e no tratamento de Mal de Parkinson (DUKE, 1997). Há ainda relatos da utilização das folhas do maracujá no combate a febres intermitentes, inflamações cutâneas, erisipela e como anti-helmínticas (CORRÊA, 1984). 
Os extratos de Passiflora têm sido utilizados na medicina popular americana e européia, devido às suas reputadas propriedades sedativa e ansiolítica (DERMARDEROSIAN; BEUTLER, 2002). Embora estas atividades tenham recebido atenção por parte dos pesquisadores no mundo, as substâncias ativas das espécies ainda não foram determinadas (PETRY et al., 2001; DHAWAN; DHAWAN; SHARMA, 2004).

Entre os compostos sugeridos como responsáveis pela atividade sedativa das passifloras estão os flavonóides (ULUBELEN; OKSUZ; MABRY, 1982), alcalóides (LUTOMSKI; MALEK, 1975) e o maltol (AOYAGI; KIMURA; MURATA, 1974).

\subsection{Aspectos químicos}

As passifloras são quimicamente constituidas por uma série de compostos, dentre eles os de maior importância medicinal e quimiotaxonômica são apresentados a seguir.

\subsubsection{Alcalóides}

Não se encontra na literatura uma divisão clara entre os alcalóides e as aminas complexas de ocorrência natural. Os alcalóides, de ocorrência limitada, derivam de fontes vegetais, são básicos, contêm um ou mais átomos de nitrogênio (usualmente em um anel heterocíclico) e geralmente possuem ação fisiológica importante em seres humanos ou em outros animais, no sistema nervoso central (TREASE; EVANS, 1996; BRUNETON, 1999).

Os alcalóides são normalmente classificados por seus precursores comuns, baseado na rota metabólica da qual a molécula deriva. Com algumas poucas exceções, o triptofano e seu produto de descarboxilação, a triptamina, são os precursores da grande classe dos alcalóides indólicos. Uma reação de Mannich envolvendo o átomo de carbono $\alpha$ do núcleo indólico produz um derivado $\beta$ carbolínico. Esta classe usualmente contém dois átomos de nitrogênio (TREASE; EVANS, 1996). 
Os alcalóides encontrados em Passiflora são $\beta$-carbolínicos (ABOURASHED; VANDERPLANCK; KHAN, 2003). São também denominados de alcalóides harmânicos, fato que remete ao isolamento de harmina e harmalina, identificados primeiramente a partir de Peganum harmala L., Zygophyllaceae (SHI et al., 2000).

As propriedades psicotrópicas dos alcalóides $\beta$-carbolínicos foram reconhecidas por índios sul-americanos desde tempos remotos. Em 1980, foi descrita a presença no sistema nervoso central de mamiferos (ROMMELSPACHER et al., 1980). São também encontrados de forma endógena em tecidos de mamiferos e possuem um amplo espectro de atividades neurofarmacológicas e psicofarmacológicas e são, por este motivo, de grande interesse para os neurofarmacologistas (SHI et al., 2000).

Os alcalóides $\beta$-carbolínicos (Figura 1) são um grupo de substâncias distribuído entre as plantas medicinais, principalmente em familias vegetais como Apocynaceae, Chenopodiaceae, Malpighiaceae, Passifloraceae, Rubiaceae, Symplocaceae, entre outras (SHI et al., 2000; ABOURASHED; VANDERPLANCK; KHAN, 2003). Entre as atividades podem-se citar a anti-hipertensiva, inibição da monoamina oxidase, recaptação de serotonina, efeitos estimulantes do sistema nervoso central, ação extrapiramidal, alucinogênica, ligação a receptores benzodiazepínicos, ações convulsivante, psicotomimética, efeitos ansiolíticos e de comportamento, atividade antioxidante, efeitos imunomodulatórios e ações cardiovasculares (ROMMELSPACHER et al., 1980; SHI et al., 2000; ABOURASHED; VANDERPLANCK; KHAN, 2003).

Segundo Rommelspacher e colaboradores (1980), a ação convulsiva do alcalóide harmana é cerca de quatro vezes maior que a do pentilenotetrazol.

Aarons, Rossi e Orzechowski (1977) descrevem a redução da pressão arterial sistêmica e a redução da resistência vascular periférica total causadas pela harmina; além disso, que reduções causadas pela harmalina são freqüentemente acompanhadas por elevação nas mesmas; e que os efeitos do harmalol para os dois parâmetros estudados são inconsistentes.

A estrutura dos alcalóides $\beta$-carbolínicos é similar à da triptamina, com a cadeia da etilamina ligada ao anel indólico através de um átomo de carbono extra, formando uma estrutura de três anéis (ROMMELSPACHER et al., 1980). 
Os principais alcalóides $\beta$-carbolínicos encontrados no gênero são: harmana, harmina, harmol, harmalina e harmalol (Figura 1, Tabela 1) (LUTOMSKI, 1959; LUTOMSKI et al., 1967). Lutomski (1960) isolou os alcalóides harmana, harmol e harmalina das folhas e dos caules de $P$. incarnata $\mathrm{L}$.

Neu $(1954 b ; 1956)$ foi um dos primeiros pesquisadores a descrever $\circ$ alcalóide harmana em espécies de Passiflora. Neu isolou harmana de $P$. incarnata e constatou que a substância era idêntica à passillorina, previamente descrita por Peckolt (1909). Posteriormente este autor sintetizou o alcalóide a partir de triptamina, triptofano e ioimbina, além de isolá-lo de $P$. edulis, $P$. alba, $P$. bryonioides, $P$. quadrangularis, $P$. capsularis e $P$. ruberosa (NEU, 1956) No primeiro trabalho do autor, da série dedicada ao estudo de $P$. incarnata (NEU, 1954a), o alcalóide foi isolado da fração insolúvel do extrato lipofilico obtido de $P$. incarnata.

Peckolt (1909) encontrou em espécies sulamericanas de Passiflora ( $P$. alata, $P$. edulis, $P$. actinia e $P$. eichleriana), duas substâncias de sabor amargo: a passiflorina e a maracujina. Das espécies estudadas, apenas $P$. edulis não apresentou a passiflorina. A passiflorina foi obtida na forma cristalina, enquanto a maracujina foi obtida na forma amorfa. $O$ autor foi o primeiro a realizar um estudo quimiossistemático dos constituintes de espécies de Passiflora.

Bennati (1967) e Bennati e Fedeli (1968) detectaram a presença de harmana, harmina e harmalina em $P$. incarnata.

Bennati (1971) propôs um método densitométrico para a determinação quantitativa dos alcalóides harmana e harmina no extrato fluido de $P$. incarnata. $O$ teor de alcalóides variou de 10 a $20 \mu \mathrm{g} \mathrm{em} 100 \mathrm{~mL}$ de extrato. Segundo o autor, a harmalina está presente no extrato fluido de $P$. incarnata em pequenas quantidades, não sendo possivel determiná-la quantitativamente, segundo o método proposto.

Poethke, Schwarz e Gerlach (1970) encontraram apenas harmana, nas concentrações de 1,2 a 3 ppm, em $P$. incarnata e não detectaram outros alcalóides $\beta$-carbolínicos na espécie.

Diversos autores detectaram harmana, harmina, harmol, harmalina e harmalol em $P$. incarnata, empregando análise cromatográfica em camada delgada. A finalidade dos estudos foi avaliar a presença de tais substâncias na droga vegetal, o que justificaria o uso da espécie como matéria-prima para preparação de 
fitoterápicos (LUTOMSKI, 1959; LUTOMSKI, 1960; LUTOMSKI et al., 1967; LUTOMSKI; ADAMSKA; JARUZELSKI, 1968; BENNATI, 1971).

Lutomski, Adamska e Jaruzelski (1968) realizaram análises qualitativas e quantitativas da droga vegetal obtida de $P$. incarnata. As amostras foram obtidas de espécies cultivadas em estufas e em culturas de solo. Os resultados mostraram-se satisfatórios nas amostras obtidas de cultura em estufa. Os alcalóides foram obtidos por extração com metanol e separação por cromatografia em camada delgada. Foi detectada a presença de harmana, harmina, harmol e harmalol para a espécie cultivada em estufas. Para as amostras obtidas de culturas de solo foi verificada a presença de traços de harmana, harmol e harmalol: harmina foi observada apenas em caules jovens. A amostra obtida de planta cultivada em estufa apresentou 0,012 a $0,019 \%$ de harmana e 0,025 a $0,032 \%$ de alcalóides totais. A droga vegetal obtida de plantas de culturas de solo apresentou traços de alcalóides.

Embora se encontre na literatura a deteç̧ão de alcalóides $\beta$-carbolínicos em diversas espécies do gênero (LUTOMSKI; MALEK; RYBACKA, 1975), sua presença em $P$. incarnata, importante planta medicinal européia e norte americana, ainda é discutivel (ABOURASHED; VANDERPLANCK; KHAN, 2003).

Com o advento de técnicas cromatográficas modernas, Rehwald, Sticher e Meier (1995) relataram discrepância em relação aos teores alcaloídicos descritos na literatura. Abourashed, Vanderplanck e Khan (2003) descreveram quantidades traço de harmana ou mesmo a ausência de alcalóides em $P$. incarnata. Alguns autores sugerem que estas variações estão relacionadas aos órgãos empregados, à época $\mathrm{e}$ ao local de coleta (REHWALD; STICHER; MEIER, 1995).

Uma hipótese plausível para as discrepâncias observadas entre os estudos realizados recentemente e no passado, é a de que as espécies estudadas hoje são quase todas cultivadas. Tal prática poderia explicar o motivo das espécies de Passiflora não apresentarem mais o teor de alcalóides que apresentavam no passado. Esta classe de compostos é considerada, entre outras possibilidades, um possivel mecanismo de defesa contra a herbivoria (HARBORNE, 2001).

Abourashed, Vanderplanck e Khan (2003) sugerem que, quando presentes em Passiflora, os alcalóides $\beta$-carbolínicos são encontrados em concentrações 
menores que 1 ppm. Nesta concentração, os autores consideram que estes compostos apresentam atividade farmacológica.

Alguns autores consideram tais substâncias as responsáveis pela atividade sedativa das espécies, isoladamente ou em corijunto com outras classes de compostos, como os flavonóides (LUTOMSKI; WROCINSKI, 1960; LUTOMSKI; ADAMSKA; JARUZELSKI, 1968; LÖHDEFINK; KATING, 1974; LUTOMSKI; MALEK; RYBACKA, 1975; MENGHINI; MANCINI, 1988).

Lutomski e Malek, em 1975, comparando o teor de alcalóides $\beta$-carbolínicos nos diferentes órgãos vegetais de $P$. edulis Sims, verificaram maior teor nas folhas, que apresentaram $0,70 \%$ de alcalóides. Os caules apresentaram $0,17 \%$. Os autores detectaram saponinas nos órgãos aéreos de $P$. edulis.

Estudo similar foi realizado, com $P$. edulis forma flavicarpa, sendo verificada a presença de alcalóides, em todos os órgãos do vegetal, exceto nas raízes (LUTOMSKI; MALEK, 1976).<smiles>[R]c1ccc2c(c1)[nH]c1c(C)nccc12</smiles>

Harmana $\mathrm{R}=\mathrm{H}$

Harmol $\mathrm{R}=\mathrm{OH}$

Harmina $\mathrm{R}=\mathrm{OCH}_{3}$<smiles>[R]c1ccc2c3c([nH]c2c1)C(C)=NCC3</smiles>

Harmalol $\mathrm{R}=\mathrm{OH}$

Harmalina $\mathrm{R}=\mathrm{OCH}_{3}$

Figura 1. Alcalóides $\beta$-carbolínicos encontrados em espécies de Passiflora L. 
Tabela 1. Alcalóides $\beta$-carbolínicos encontrados em espécies de Passiflora L.

\begin{tabular}{|c|c|c|c|}
\hline Espécies & Órgãos & Substâncias & Referências \\
\hline P. alata & folhas & harmana & Freitas (1985) \\
\hline P. allantophylla & folhas & harmana, harmina & $\begin{array}{l}\text { Abourashed, } \\
\text { Vanderplanck e } \\
\text { Khan (2003) }\end{array}$ \\
\hline P. bryonioides & $\begin{array}{l}\text { folhas, caules, } \\
\text { raízes }\end{array}$ & harmana & $\begin{array}{l}\text { Poethke, } \\
\text { Schwarz e } \\
\text { Gerlach (1970) }\end{array}$ \\
\hline P. coriacea & folhas & harmina & $\begin{array}{l}\text { Abourashed, } \\
\text { Vanderplanck e } \\
\text { Khan (2003) }\end{array}$ \\
\hline P. edulis & folhas & harmana & Freitas (1985) \\
\hline P. edulis & folhas & $\begin{array}{l}\text { harmana, harmina, } \\
\text { harmalina }\end{array}$ & $\begin{array}{l}\text { Abourashed, } \\
\text { Vanderplanck e } \\
\text { Khan (2003) }\end{array}$ \\
\hline $\begin{array}{l}P . \text { foetida forma } \\
\text { hibiscifolia }\end{array}$ & folhas & harmina & $\begin{array}{l}\text { Abourashed, } \\
\text { Vanderplanck e } \\
\text { Khan (2003) }\end{array}$ \\
\hline $\begin{array}{l}P . \text { foetida forma } \\
\text { gossipifolia }\end{array}$ & folhas & $\begin{array}{l}\text { harmol, harmana, } \\
\text { harmalina, harmina }\end{array}$ & $\begin{array}{l}\text { Abourashed, } \\
\text { Vanderplanck e } \\
\text { Khan (2003) }\end{array}$ \\
\hline P. guatemalensis & folhas & $\begin{array}{l}\text { harmalol, harmina, } \\
\text { harmol, harmalina, } \\
\text { harmana }\end{array}$ & $\begin{array}{l}\text { Abourashed, } \\
\text { Vanderplanck e } \\
\text { Khan (2003) } \\
\end{array}$ \\
\hline P. hybrida & folhas & $\begin{array}{l}\text { harmalol, harmol, } \\
\text { harmana, harmalina, } \\
\text { harmina }\end{array}$ & $\begin{array}{l}\text { Abourashed, } \\
\text { Vanderplanck e } \\
\text { Khan (2003) }\end{array}$ \\
\hline$P$. incarnata & folhas & $\begin{array}{l}\text { harmana, harmalina, } \\
\text { harmalol, harmina }\end{array}$ & $\begin{array}{l}\text { Poethke, } \\
\text { Schwarz e } \\
\text { Gerlach (1970) }\end{array}$ \\
\hline$P$. incarnata & folhas & harmana & Freitas (1985) \\
\hline$P$. incarnata & folhas & harmina & $\begin{array}{l}\text { Aoyagi, Kimura } \\
\text { e Murata (1974) }\end{array}$ \\
\hline P. incarnata & folhas & $\begin{array}{l}\text { harmalol, harmol, } \\
\text { harmana, harmalina, } \\
\text { harmina }\end{array}$ & $\begin{array}{l}\text { Abourashed, } \\
\text { Vanderplanck e } \\
\text { Khan (2003) }\end{array}$ \\
\hline
\end{tabular}


Tabela 1. Continuação

\begin{tabular}{|c|c|c|c|}
\hline Espécies & Órgãos & Substâncias & Referências \\
\hline P. laurifolia & folhas & harmalina, harmina & $\begin{array}{l}\text { Abourashed, } \\
\text { Vanderplanck e } \\
\text { Khan (2003) }\end{array}$ \\
\hline P. manicata & folhas & harmalina, harmina & $\begin{array}{l}\text { Abourashed, } \\
\text { Vanderplanck e } \\
\text { Khan (2003) }\end{array}$ \\
\hline P. menispermifolia & folhas & harmana, harmalina & $\begin{array}{l}\text { Abourashed, } \\
\text { Vanderplanck e } \\
\text { Khan (2003) }\end{array}$ \\
\hline P. multiflora & folhas & $\begin{array}{l}\text { harmana, harmalina, } \\
\text { harmina }\end{array}$ & $\begin{array}{l}\text { Abourashed, } \\
\text { Vanderplanck e } \\
\text { Khan (2003) }\end{array}$ \\
\hline P. perfoliata & folhas & $\begin{array}{l}\text { harmana, harmalina, } \\
\text { harmina }\end{array}$ & $\begin{array}{l}\text { Abourashed, } \\
\text { Vanderplanck e } \\
\text { Khan (2003) }\end{array}$ \\
\hline P. racemosa & folhas & harmalina, harmina & $\begin{array}{l}\text { Abourashed, } \\
\text { Vanderplanck e } \\
\text { Khan (2003) }\end{array}$ \\
\hline P. rubra & folhas & $\begin{array}{l}\text { harmana, harmalina, } \\
\text { harmina }\end{array}$ & $\begin{array}{l}\text { Abourashed, } \\
\text { Vanderplanck e } \\
\text { Khan (2003) }\end{array}$ \\
\hline$P$. sexflora & folhas & $\begin{array}{l}\text { harmol, harmana, } \\
\text { harmina }\end{array}$ & $\begin{array}{l}\text { Abourashed, } \\
\text { Vanderplanck e } \\
\text { Khan (2003) }\end{array}$ \\
\hline
\end{tabular}

\subsubsection{Flavonóides}

Os flavonóides, quimicamente classificados como 2-fenil-1,4-benzopironas (PARR; BOLWELL, 2000), com cerca de nove mil estruturas identificadas, estão presentes em praticamente todas as plantas vasculares estudadas (MARTENS; MITHÖFER, 2005). O termo flavonóide provém do latim flavus, que significa amarelo. Nas plantas superiores suas funções incluem, entre outras, a pigmentação de flores e a proteção contra o ataque de predadores (MARTENS; MITHÖFER, 2005). 
Os flavonóides são os constituintes majoritários da maioria das espécies de Passiflora (Figura 2, Tabela 2), sendo que os C-glicosideos predominam (QIMIN et al., 1991; ABOURASHED; VANDERPLANCK; KHAN, 2002; BIRK et al., 2005; MÜLLER et al., 2005). Alguns autores atribuem a atividade sedativa das espécies aos flavonóides (LUTOMSKI; WROCINSKI, 1960; LUTOMSKI; ADAMSKA; JARUZELSKI, 1968; LUTOMSKI; MALEK; RYBACKA, 1975; LÖHDEFINK; KATING, 1974; MENGHINI; MANCINI, 1988).

Os estudos dos flavonóides do gênero descrevem, em sua maioria, compostos derivados da apigenina e da luteolina (GEIGER; MARKHAM, 1986; ABOURASHED; VANDERPLANCK; KHAN, 2002). Os principais flavonóides detectados nas espécies de Passiflora foram orientina, isoorientina, vitexina e isovitexina (ABOURASHED; VANDERPLANCK; KHAN, 2002).

Segundo Qimin e colaboradores (1991), os métodos cromatográficos em camada delgada e cromatografia líquida de alta eficiência, utilizados na análise e identificação de extratos de $P$. incarnata dependem de padrões, nem sempre disponíveis. Segundo os autores, apenas um estudo foi encontrado em que estavam presentes espectros de ressonância magnética nuclear e espectros de massas consistentes (GEIGER; MARKHAM, 1986); estes últimos identificaram isovitexina, isoorientina, schaftosídeo, isoschaftosideo, 2-vicenina, 2"-O-glicopiranosil-isovitexina e 2"-O-glicopiranosil-isoorientina como componentes principais de $P$. incarnata. Os resultados obtidos por Qimin e colaboradores (1991) estão de acordo com os obtidos por Geiger e Markham (1986).

Os dados encontrados na literatura sobre a quantificação dos flavonóides são contraditórios, pois a fração flavonoídica está sujeita à variação no seu conteúdo devido à época de colheita, ao local de cultivo ou à metodologia de análise empregada (MENGHINI; MANCINI, 1988). Schilcher (1968) mostrou teores diferentes em função de órgãos; as folhas e as flores de $P$. incarnata são relativamente equivalentes quanto ao teor de flavonóides totais, enquanto que, no caule, ocorrem em proporções aproximadamente quatro vezes menores.

Menghiri e Manciri (1988) analisaram a sazonalidade de flavonóides durante o ciclo ontogênico de $P$. incarnata. Os autores determinaram os flavonóides totais através de espectrofotometria no ultravioleta-visivel, utilizando extratos metanólicos das drogas vegetais e verificaram que o teor é maior nas folhas $(3,05 \%)$, no período 
que antecede a floração $(3,60 \%)$ e no periodo de floração do vegetal $(3,91 \%)$. Nos frutos e sementes foram detectados traços de isovitexina, e nos caules um quinto do teor das folhas.

Dhawan e colaboradores (2001) isolaram uma benzoflavona trissubstituída, de extratos metanólicos de $P$. incarnata, à qual atribuíram atividade sedativa em camundongos. No entanto, sua estrutura não foi completamente divulgada, por motivos de patente (DHAWAN; DHAWAN; SHARMA, 2004).<smiles>[R]c1cc(-c2cc(=O)c3c(O)c([R])c(O)c([R])c3o2)ccc1O</smiles>

$$
\begin{array}{lll}
\text { Orientina } & R_{1}=H \quad R_{2}=g l c R_{3}=O H \\
\text { Isoorientina } R_{1}=g l c & R_{2}=H \quad R_{3}=O H \\
\text { Vitexina } \quad R_{1}=H \quad R_{2}=g l c \quad R_{3}=H \\
\text { Isovitexina } \quad R_{1}=g l c & R_{2}=H \quad R_{3}=H
\end{array}
$$

$$
\text { glc = glicose }
$$

Figura 2. Flavonóides encontrados em espécies de Passiflora L. 
Tabela 2. Flavonóides encontrados em espécies de Passiflora L.

\begin{tabular}{|c|c|c|c|}
\hline Espécies & Órgãos & Substâncias & Referências \\
\hline P. adenopoda & folhas & $\begin{array}{l}\text { chaftosídeo, } \\
\text { isochaftosídeo }\end{array}$ & $\begin{array}{l}\text { Abourashed, } \\
\text { Vanderplanck e } \\
\text { Khan (2002) }\end{array}$ \\
\hline P. alata & folhas & $\begin{array}{l}\text { 2"-xilosilvitexina, } \\
\text { vitexina, orientina }\end{array}$ & $\begin{array}{l}\text { Ulubelen, Oksuz } \\
\text { e Mabry (1982) }\end{array}$ \\
\hline P. alata & folhas & $\begin{array}{l}\text { orientina, isoorientina, } \\
\text { isovitexina, vitexina, } \\
\text { rutina }\end{array}$ & Freitas (1985) \\
\hline P. alata & folhas & $\begin{array}{l}\text { vitexina (traços), } \\
\text { isovitexina }\end{array}$ & $\begin{array}{l}\text { Müller et al. } \\
(2005)\end{array}$ \\
\hline P. alata & folhas & $\begin{array}{l}\text { isoorientina, isovitexina, } \\
\text { 2"-O-ramnosil-vitexina, } \\
\text { 2"--O-ramnosil- } \\
\text { escoparina, 2"-O- } \\
\text { ramnosil-orientina }\end{array}$ & $\begin{array}{l}\text { Doyama et al. } \\
\text { (2005) }\end{array}$ \\
\hline P. allantophylla & folhas & $\begin{array}{l}\text { vitexina, chaftosídeo, } \\
\text { isochaftosídeo, } \\
\text { isoorientina, orientina, } \\
\text { isovitexina }\end{array}$ & $\begin{array}{l}\text { Abourashed, } \\
\text { Vanderplanck e } \\
\text { Khan (2002) }\end{array}$ \\
\hline P. ambigua & folhas & saponarina & $\begin{array}{l}\text { Ulubelen, Oksuz } \\
\text { e Mabry (1982) }\end{array}$ \\
\hline P. ampullacea & folhas & $\begin{array}{l}\text { chaftosídeo, } \\
\text { isochaftosídeo, } \\
\text { isoorientina, orientina, } \\
\text { isovitexina, vitexina }\end{array}$ & $\begin{array}{l}\text { Abourashed, } \\
\text { Vanderplanck e } \\
\text { Khan (2002) }\end{array}$ \\
\hline P. anfracta & folhas & orientina, isoorientina & $\begin{array}{l}\text { Abourashed, } \\
\text { Vanderplanck e } \\
\text { Khan (2002) }\end{array}$ \\
\hline P. biflora & folhas & $\begin{array}{l}\text { isoorientina, isovitexina, } \\
\text { vitexina }\end{array}$ & $\begin{array}{l}\text { Abourashed, } \\
\text { Vanderplanck e } \\
\text { Khan (2002) }\end{array}$ \\
\hline P. bryonioides & $\begin{array}{l}\text { folhas, caules, } \\
\text { raizes }\end{array}$ & $\begin{array}{l}\text { saponaretina, vitexina, } \\
\text { apigenina, canferol }\end{array}$ & $\begin{array}{l}\text { Poethke, } \\
\text { Schwarz e } \\
\text { Gerlach (1970) }\end{array}$ \\
\hline P. caerulea & folhas & $\begin{array}{l}\text { derivados da apigenina } \\
\text { e luteolina }\end{array}$ & Tronchet (1978) \\
\hline P. caerulea & folhas, caules & crisina & $\begin{array}{l}\text { Medina et al. } \\
(1990)\end{array}$ \\
\hline
\end{tabular}


Tabela 2. Continuação

\begin{tabular}{|c|c|c|c|}
\hline Espécies & Órgãos & Substâncias & Referências \\
\hline P. caerulea & folhas & isoorientina & $\begin{array}{l}\text { Pastene, Montes } \\
\text { e Vega (1997) }\end{array}$ \\
\hline P. caerulea & folhas & $\begin{array}{l}\text { chaftosídeo, } \\
\text { isochaftosídeo, } \\
\text { vitexina, isoorientina, } \\
\text { isovitexina }\end{array}$ & $\begin{array}{l}\text { Abourashed, } \\
\text { Vanderplanck e } \\
\text { Khan (2002) }\end{array}$ \\
\hline P. coactilis & folhas & $\begin{array}{l}\text { vitexina, isovitexina, } \\
\text { orientina, escoparina }\end{array}$ & $\begin{array}{l}\text { Escobar, Liut e } \\
\text { Mabry (1983) }\end{array}$ \\
\hline P. coliinvauxii & folhas, caules & $\begin{array}{l}\text { chaftosídeo, } \\
\text { isochaftosídeo, } \\
\text { isoorientina, orientina, } \\
\text { isovitexina }\end{array}$ & $\begin{array}{l}\text { Abourashed, } \\
\text { Vanderplanck e } \\
\text { Khan (2002) }\end{array}$ \\
\hline P. coriacea & folhas & isoorientina, vitexina & $\begin{array}{l}\text { Abourashed, } \\
\text { Vanderplanck e } \\
\text { Khan (2002) }\end{array}$ \\
\hline P. cuneata & folhas, caules & $\begin{array}{l}\text { chaftosídeo, } \\
\text { isochaftosídeo, } \\
\text { orientina, isoorientina }\end{array}$ & $\begin{array}{l}\text { Abourashed, } \\
\text { Vanderplanck e } \\
\text { Khan (2002) }\end{array}$ \\
\hline P. cyanea & folhas & 2"-xilosilvitexina & $\begin{array}{l}\text { Ulubelen, } \\
\text { Ayyildiz e Mabry } \\
\text { (1981) }\end{array}$ \\
\hline P. discophora & folhas & $\begin{array}{l}\text { chaftosídeo, } \\
\text { isochaftosídeo, } \\
\text { isovitexina }\end{array}$ & $\begin{array}{l}\text { Abourashed, } \\
\text { Vanderplanck e } \\
\text { Khan (2002) } \\
\end{array}$ \\
\hline P. edulis & folhas & $\begin{array}{l}\text { orientina, isovitexina, } \\
\text { vitexina, isovitexina }\end{array}$ & Freitas (1985) \\
\hline P. edulis & folhas & $\begin{array}{l}\text { chinovosídeo-6-C- } \\
\text { luteolina, fucosídeo-6- } \\
\text { C-luteolina }\end{array}$ & $\begin{array}{l}\text { Mareck et al. } \\
\text { (1991) }\end{array}$ \\
\hline P. edulis & folhas & $\begin{array}{l}\text { vitexina, isovitexina, } \\
\text { isoorientina, orientina }\end{array}$ & $\begin{array}{l}\text { Petry et al. } \\
(2001)\end{array}$ \\
\hline $\begin{array}{l}P \text {. edulis variedade } \\
\text { golden nugget }\end{array}$ & folhas & $\begin{array}{l}\text { chaftosideo, } \\
\text { isochaftosídeo, } \\
\text { orientina, isovitexina, } \\
\text { isoorientina }\end{array}$ & $\begin{array}{l}\text { Abourashed, } \\
\text { Vanderplanck e } \\
\text { Khan (2002) }\end{array}$ \\
\hline$P$. filipes & folhas & $\begin{array}{l}\text { chaftosídeo, } \\
\text { isochaftosídeo, } \\
\text { orientina, isovitexina, } \\
\text { isoorientina }\end{array}$ & $\begin{array}{l}\text { Abourashed, } \\
\text { Vanderplanck e } \\
\text { Khan (2002) }\end{array}$ \\
\hline
\end{tabular}


Tabela 2. Continuação

\begin{tabular}{|c|c|c|c|}
\hline Espécies & Órgãos & Substâncias & Referências \\
\hline P. foetida & sementes & $\begin{array}{l}\text { chaftosídeo, } \\
\text { isochaftosídeo, } \\
\text { isoorientina, isovitexina, } \\
\text { orientina, vitexina }\end{array}$ & $\begin{array}{l}\text { Abourashed, } \\
\text { Vanderplanck e } \\
\text { Khan (2002) }\end{array}$ \\
\hline $\begin{array}{l}\text { P. foetida forma } \\
\text { hispida }\end{array}$ & folhas & $\begin{array}{l}\text { flavonóides C- } \\
\text { glicosilados }\end{array}$ & $\begin{array}{l}\text { Ulubelen et al. } \\
\text { (1982) }\end{array}$ \\
\hline $\begin{array}{l}\text { P. foetida forma } \\
\text { hibiscifolia }\end{array}$ & folhas & $\begin{array}{l}\text { flavonóides } C \text { - } \\
\text { glicosilados }\end{array}$ & $\begin{array}{l}\text { Ulubelen et al. } \\
\text { (1982) }\end{array}$ \\
\hline P. gilbertiana & folhas & $\begin{array}{l}\text { chaftosideo, } \\
\text { isochaftosídeo, } \\
\text { isoorientina, orientina, } \\
\text { isovitexina }\end{array}$ & $\begin{array}{l}\text { Abourashed, } \\
\text { Vanderplanck e } \\
\text { Khan (2002) }\end{array}$ \\
\hline P. gracilis & folhas & $\begin{array}{l}\text { chaftosideo, } \\
\text { isochaftosídeo, } \\
\text { isovitexina, vitexina }\end{array}$ & $\begin{array}{l}\text { Abourashed, } \\
\text { Vanderplanck e } \\
\text { Khan (2002) }\end{array}$ \\
\hline P. holosericea & folhas & orientina, vitexina & $\begin{array}{l}\text { Abourashed, } \\
\text { Vanderplanck e } \\
\text { Khan (2002) }\end{array}$ \\
\hline P. incarnata & folhas, caules & $\begin{array}{l}\text { saponarina, } \\
\text { saponaretina, vitexina, } \\
\text { isoorientina }\end{array}$ & $\begin{array}{l}\text { Glotzbach, } \\
\text { Rimpler (1968) }\end{array}$ \\
\hline P. incarnata & folhas & $\begin{array}{l}\text { apigenina, luteolina, } \\
\text { quercetina, canferol }\end{array}$ & $\begin{array}{l}\text { Gavasheli, } \\
\text { Moniava e } \\
\text { Eristavi (1974) }\end{array}$ \\
\hline P. incarnata & folhas & vitexina, isovitexina & $\begin{array}{l}\text { Lutomski e } \\
\text { Wrocinski (1960) }\end{array}$ \\
\hline P. incarnata & folhas & $\begin{array}{l}\text { vitexina, isovitexina, } \\
\text { orientina, isoorientina }\end{array}$ & Freitas (1985) \\
\hline P. incarnata & folhas & vitexina, isovitexina & $\begin{array}{l}\text { Pietta et al. } \\
\text { (1989) }\end{array}$ \\
\hline P. incarnata & folhas & $\begin{array}{l}\text { chaftosídeo, } \\
\text { isochaftosídeo, } \\
\text { isovitexina, isoorientina, } \\
\text { vicenina, 2"-O- } \beta \text { - } \\
\text { glicopiranosil- } \\
\text { isovitexina, 2"-O- } \beta \text { - } \\
\text { glicopiranosil- } \\
\text { isoorientina }\end{array}$ & $\begin{array}{l}\text { Geiger, } \\
\text { Markham (1986) }\end{array}$ \\
\hline
\end{tabular}


Tabela 2. Continuação

\begin{tabular}{|c|c|c|c|}
\hline Espécies & Órgãos & Substâncias & Referências \\
\hline P. incarnata & folhas & $\begin{array}{l}\text { chaftosídeo, } \\
\text { isochaftosídeo, 2"-O- } \\
\text { glicopiranosil- } \\
\text { isovitexina, 2"-O- } \\
\text { glicopiranosil- } \\
\text { isoorientina } \\
\end{array}$ & $\begin{array}{l}\text { Qimin et al. } \\
\text { (1991) }\end{array}$ \\
\hline$P$. incarnata & folhas & $\begin{array}{l}\text { esvertisina, isovitexina, } \\
\text { isoorientina, } \\
\text { chaftosídeo, } \\
\text { isochaftosídeo }\end{array}$ & $\begin{array}{l}\text { Rehwald et al. } \\
\text { (1994) }\end{array}$ \\
\hline$P$. incarnata & folhas & $\begin{array}{l}\text { 2"-O-glicosil- } \\
\text { isoescoparina }\end{array}$ & $\begin{array}{l}\text { Rahman et al. } \\
(1997)\end{array}$ \\
\hline P. incarnata & folhas & $\begin{array}{l}\text { chaftosídeo, } \\
\text { isochaftosideo, } \\
\text { isoorientina, orientina, } \\
\text { isovitexina, vitexina }\end{array}$ & $\begin{array}{l}\text { Abourashed, } \\
\text { Vanderplanck e } \\
\text { Khan (2002) }\end{array}$ \\
\hline P. laurifolia & folhas & orientina, vitexina & $\begin{array}{l}\text { Abourashed, } \\
\text { Vanderplanck e } \\
\text { Khan (2002) }\end{array}$ \\
\hline P. manicata & folhas & $\begin{array}{l}\text { isoorientina, orientina, } \\
\text { isovitexina, vitexina }\end{array}$ & $\begin{array}{l}\text { Abourashed, } \\
\text { Vanderplanck e } \\
\text { Khan (2002) }\end{array}$ \\
\hline P. menispermifolia & folhas & $\begin{array}{l}\text { vitexina, orientina, } \\
\text { glicosil-7- } \beta \text {-D-luteolina, } \\
\text { esculetina }\end{array}$ & $\begin{array}{l}\text { Ulubelen, } \\
\text { Ayyildiz e Mabry } \\
\text { (1981) }\end{array}$ \\
\hline P. oerstedii & folhas & 2"-xilosilvitexina & $\begin{array}{l}\text { Ulubelen, } \\
\text { Ayyildiz e Mabry } \\
\text { (1981) }\end{array}$ \\
\hline P. palmeri & folhas & $\begin{array}{l}\text { isovitexina, } \\
\text { isoescoparina, dimetil } \\
\text { éter-7,3'-quercetina, } \\
\text { vitexina, quercetina, } \\
\text { glicosil-7-apigenina, } \\
\text { luteolina, isoorientina, } \\
\text { 2-vicenina, 6-metoxi- } \\
\text { canferol }\end{array}$ & $\begin{array}{l}\text { Ulubelen et al. } \\
\text { (1984) }\end{array}$ \\
\hline
\end{tabular}


Tabela 2. Continuação

\begin{tabular}{|c|c|c|c|}
\hline Espécies & Órgãos & Substâncias & Referências \\
\hline P. pavonis & folhas & $\begin{array}{l}\text { glicosil-4'- } \beta \text {-D- } \\
\text { isoorientina, isovitexina, } \\
\text { isoorientina, glicosil-7- } \\
\beta \text {-D-luteolina }\end{array}$ & $\begin{array}{l}\text { McCormick, } \\
\text { Mabry (1981) }\end{array}$ \\
\hline P. perfoliata & folhas & isovitexina & $\begin{array}{l}\text { Abourashed, } \\
\text { Vanderplanck e } \\
\text { Khan (2002) } \\
\end{array}$ \\
\hline P. pittieri & folhas & $\begin{array}{l}\text { isovitexina, vicenina, } \\
\text { chaftosideo, } \\
\text { isochaftosideo, 2"- } \\
\text { xilosilvitexina, glicosil-7- } \\
\text { O-luteolina }\end{array}$ & $\begin{array}{l}\text { Ulubelen, Oksuz } \\
\text { e Mabry (1982) }\end{array}$ \\
\hline P. platiloba & folhas & $\begin{array}{l}\text { chaftosideo, } \\
\text { isochaftosideo, } \\
\text { isoorientina, orientina, } \\
\text { isovitexina, vitexina }\end{array}$ & $\begin{array}{l}\text { Abourashed, } \\
\text { Vanderplanck e } \\
\text { Khan (2002) }\end{array}$ \\
\hline P. pulchella & folhas, caules & $\begin{array}{l}\text { saponarina, } \\
\text { saponaretina, vitexina, } \\
\text { isoorientina }\end{array}$ & $\begin{array}{l}\text { Glotzbach, } \\
\text { Rimpler (1968) }\end{array}$ \\
\hline P. quadrangularis & folhas, caules & $\begin{array}{l}\text { saponarina, } \\
\text { saponaretina, vitexina }\end{array}$ & $\begin{array}{l}\text { Glotzbach, } \\
\text { Rimpler (1968) }\end{array}$ \\
\hline P. quadrangularis & folhas & $\begin{array}{l}\text { vitexina, orientina, } \\
\text { isovitexina, isoorientina }\end{array}$ & Freitas (1985) \\
\hline P. sanguinolenta & folhas & $\begin{array}{l}\text { isovitexina, luteolina, } \\
\text { galactosil-7-O- } \\
\text { luteolina, xilosilvitexina, } \\
\text { apigenina, glicosil-7-0- } \\
\text { apigenina }\end{array}$ & $\begin{array}{l}\text { Ulubelen, Mabry } \\
\text { (1983) }\end{array}$ \\
\hline$P$. serratifolia & folhas & $\begin{array}{l}\text { chaftosídeo, } \\
\text { isochaftosídeo, } \\
\text { isoorientina, orientina }\end{array}$ & $\begin{array}{l}\text { Abourashed, } \\
\text { Vanderplanck e } \\
\text { Khan (2002) }\end{array}$ \\
\hline P. serratifolia & folhas & $\begin{array}{l}\text { vitexina, isovitexina, } \\
\text { orientina, 2"- } \\
\text { xilosilvitexina, 2"- } \\
\text { xilosilisovitexina }\end{array}$ & $\begin{array}{l}\text { Ulubelen, Mabry } \\
\text { (1980) }\end{array}$ \\
\hline
\end{tabular}


Tabela 2. Continuação

\begin{tabular}{|c|c|c|c|}
\hline Espécies & Órgãos & Substâncias & Referências \\
\hline P. serratodigitata & órgãos aéreos & $\begin{array}{l}\text { serratina, } 7-\beta \\
\text { glicosilserratina, } 2 "- \\
\text { xilosilvitexina, vitexina, } \\
\text { isovitexina, vicenina, } \\
\text { orientina, crisina }\end{array}$ & $\begin{array}{l}\text { Ulubelen, Kerr, } \\
\text { Mabry (1982) }\end{array}$ \\
\hline P. sexflora & folhas & $\begin{array}{l}\text { lucenina, carlinosideo, } \\
\text { isoviolantina, } \\
\text { chaftosídeo, vicenina, } \\
\text { isochaftosideo, } \\
\text { orientina, isoorientina, } \\
\text { vitexina, } \\
\text { isoesvertiajaponina, } \\
\text { luteolina, isoesvertisina, } \\
\text { esvertiajaponina, } \\
\text { glicosil-7-O-luteolina, } \\
\text { aurona }\end{array}$ & $\begin{array}{l}\text { McCormick, } \\
\text { Mabry (1982) }\end{array}$ \\
\hline P. sexflora & folhas & $\begin{array}{l}\text { chaftosídeo, } \\
\text { isochaftosídeo, } \\
\text { isoorientina, isovitexina }\end{array}$ & $\begin{array}{l}\text { Abourashed, } \\
\text { Vanderplanck e } \\
\text { Khan (2002) }\end{array}$ \\
\hline P. trinervia & folhas & $\begin{array}{l}\text { vitexina, isovitexina, } \\
\text { galactosil-7-O- } \\
\text { luteolina, esculetina, } \\
\text { isoorientina }\end{array}$ & $\begin{array}{l}\text { Ulubelen, Mabry } \\
\text { (1983) }\end{array}$ \\
\hline
\end{tabular}

\subsubsection{Glicosídeos cianogênicos}

Os glicosídeos cianogênicos são substâncias encontradas em cerca de 3000 espécies, incluidas em 110 famílias. Cianogênese, um mecanismo de defesa ativado através de enzimas, é um processo que plantas e outros organismos possuem de liberar ácido cianídrico (CHASSAGNE; CROUZET, 1998).

Nas plantas, o ácido cianídrico provém da hidrólise dos glicosídeos cianogênicos, derivados glicosilados das $\alpha$-hidroxinitrilas. Suas agliconas têm origem geralmente em aminoácidos aromáticos, alifáticos ou ciclopentanóides (CHASSAGNE et al., 1996). 
Os glicosídeos cianogênicos podem ser encontrados nos frutos e folhas secas de espécies da familia Rosaceae, tais como, Prunus avium (L.) L. (cerejas), Malus domestica Borkh. (maçãs), Prunus dulcis (Mill.) Webb (amêndoas), Prunus persica (L.) Batsch (pêssegos), entre outros (BRUNETON, 1999).

Segundo Hegnauer (1990), Passifloraceae caracteriza-se pela presença de glicosídeos cianogênicos ciclopentanóides. A família divide esta característica com plantas das familias Turneraceae, Malesherbiaceae e Achariaceae, entre outras.

Os glicosídeos cianogênicos de Passiflora (Figuras 3, 4 e 5, Tabela 3) diferem na estrutura e no teor entre as espécies do gênero, possibilitando distinções e classificações (JAROSZEWSKI et al., 2002).

Jaroszewski e colaboradores (2002) dividiram, para fins didáticos, os glicosídeos cianogênicos de Passifloraceae em quatro grupos distintos, de acordo com as estruturas químicas. O primeiro grupo inclui os $\beta$-D-glicopiranosídeos das cianoidrinas enantioméricas da 2-ciclopentenona - tetrafilina $A$, deidaclina, tetrafilina $B$, volquenina, epivolquenina e taractofilina (Figura 3); o segundo grupo inclui compostos que contêm um grupo sulfato ou oxigenação no anel ciclopenteno. São considerados estruturalmente mais complexos em relação aos compostos do grupo 1 - incluem a passibiflorina, passicapsina, passitrifasciatina, sulfato de tetrafilina $B$, suberina A e ginocardina (Figura 4). Acredita-se que os glicosídeos pertencentes aos grupos 1 e 2 sejam biossintetizados a partir da 2-ciclopentenilglicina, embora a possibilidade de origem a partir de aminoácidos oxigenados não possa ser excluída.

O terceiro grupo inclui linamarina, lotaustralina, linustatina, neolinustatina e epilotaustralina (Figura 5). Embora estes glicosídeos não contenham o anel ciclopenteno, os seus aminoácidos precursores (valina e isoleucina) ocupam um espaço conformacional semelhante ao da 2-ciclopentenilglicina. Já o quarto grupo consiste de prunasina, amidalina e passiedulina, todos isolados de $P$. edulis (Figura 5). Os autores assumem que estes glicosideos originam-se a partir da fenilalanina (JAROSZEWSKI et al., 2002). 


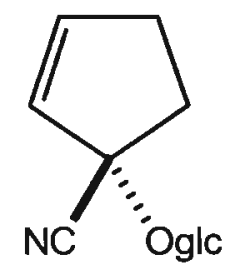

Tetrafilina A

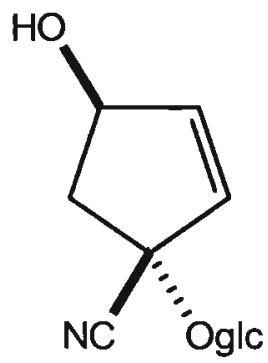

Volquenina

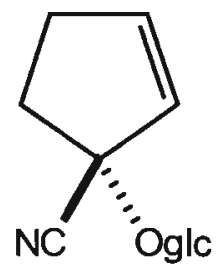

Deidaclina

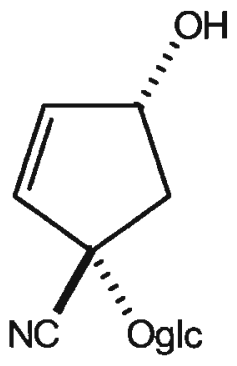

Epivolquenina

glc $=$ glicose

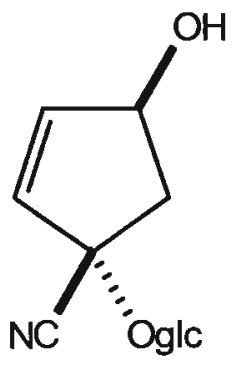

Tetrafilina B<smiles>N#C[C@]1(O)C=C[C@@H](O)C1</smiles>

Taractofilina

Figura 3. Glicosídeos cianogênicos do grupo 1 encontrados em espécies de Passiflora L. (JAROSZEWSKI et al., 2002). 


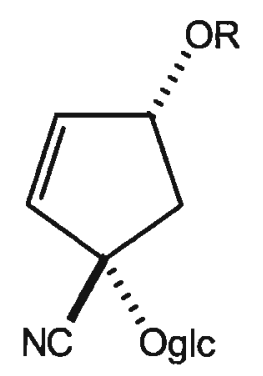

$\begin{array}{ll}\text { Passibiflorina } & R=6 \text {-deoxi- } \beta \text {-D-gulopiranosil } \\ \text { Passicapsina } & R=2,6 \text {-dideoxi- } \beta \text {-D-xilo-hexopiranosil } \\ \text { Passitrifasciatina } & R=6 \text {-deoxi- } \beta \text {-D-alopiranosil }\end{array}$
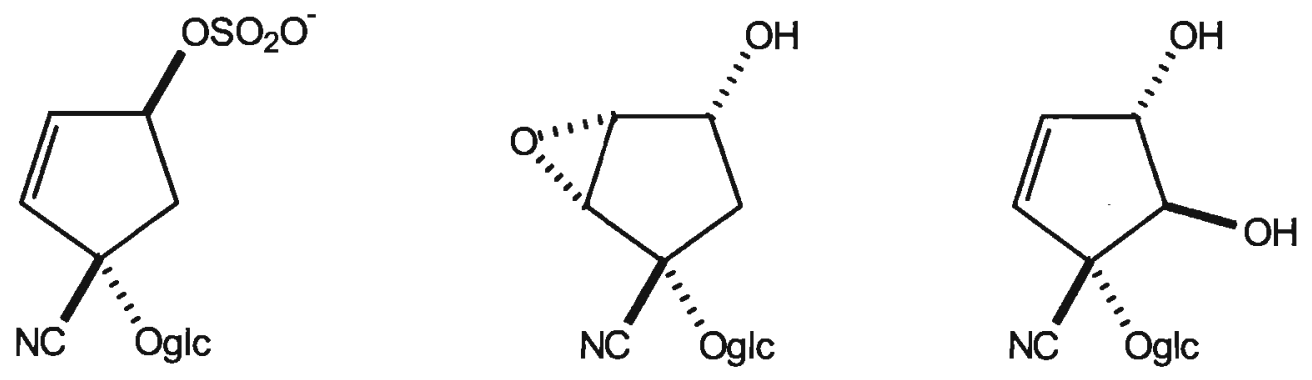

Sulfato de tetrafilina B

$$
\text { glc = glicose }
$$

Figura 4. Glicosídeos cianogênicos do grupo 2 encontrados em espécies de Passiflora L. (JAROSZEWSKI et al., 2002). 
Grupo 3

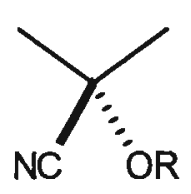

NC OR

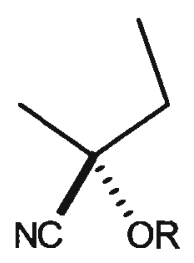

OR

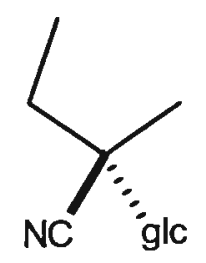

Epilotaustralina

$\begin{array}{ll}\text { Linamarina } R=g l c & \text { Lotaustralina } R=g l c \\ \text { Linustatina } R=\text { glcglc } & \text { Neolinustatina } R=\text { glcglc }\end{array}$

\section{Grupo 4}

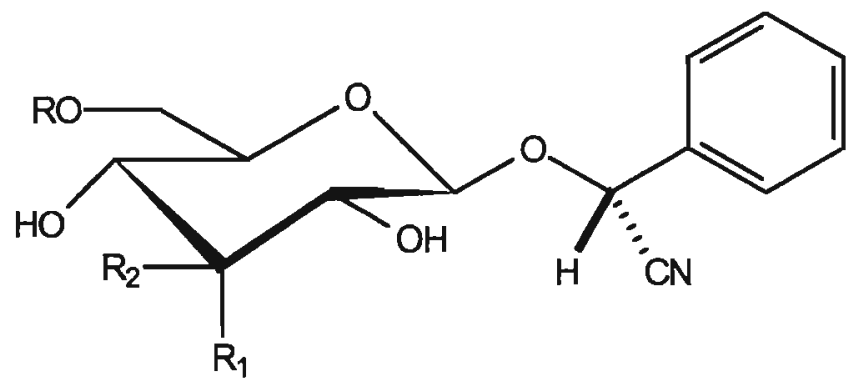

$\begin{array}{lll}\text { Prunasina } & \mathrm{R}=\mathrm{H} \quad \mathrm{R}_{1}=\mathrm{H} \quad \mathrm{R}_{2}=\mathrm{OH} \\ \text { Amidalina } & \mathrm{R}=\mathrm{glc} \mathrm{R}_{1}=\mathrm{H} \quad \mathrm{R}_{2}=\mathrm{OH} \\ \text { Passiedulina } & \mathrm{R}=\mathrm{H} \quad \mathrm{R}_{1}=\mathrm{OH} \mathrm{R}_{2}=\mathrm{H}\end{array}$

glc $=$ glicose

Figura 5. Glicosídeos cianogênicos dos grupos 3 e 4 encontrados em espécies de Passiflora L. (JAROSZEWSKI et al., 2002). 
Tabela 3. Glicosideos cianogênicos encontrados em espécies de Passiflora L.

\begin{tabular}{|c|c|c|c|}
\hline Espécies & Órgãos & Substâncias & Referências \\
\hline$P$. adenopoda & folhas & $\begin{array}{l}\text { linamarina, } \\
\text { lotaustraliana }\end{array}$ & $\begin{array}{l}\text { Spencer, Seigler } \\
\text { e Nahrstedi } \\
\text { (1986) }\end{array}$ \\
\hline P. alato-caerulea & folhas & $\begin{array}{l}\text { tetrafilina B, sulfato de } \\
\text { epitetrafilina B }\end{array}$ & $\begin{array}{l}\text { Seigler et al. } \\
(1982)\end{array}$ \\
\hline P. apetala & folhas, caules & passibiflorina & $\begin{array}{l}\text { Jaroszewski et } \\
\text { al. (2002) }\end{array}$ \\
\hline P. biflora & folhas & $\begin{array}{l}\text { passibiflorina, } \\
\text { epipassibiflorina }\end{array}$ & $\begin{array}{l}\text { Spencer, Seigler } \\
(1985)\end{array}$ \\
\hline$P$. biflora & folhas, caules & passibiflorina & $\begin{array}{l}\text { Jaroszewski et } \\
\text { al. (2002) }\end{array}$ \\
\hline P. caerulea & folhas & $\begin{array}{l}\text { tetrafilina B, } \\
\text { epitetrafilina B }\end{array}$ & $\begin{array}{l}\text { Seigler et al. } \\
(1982)\end{array}$ \\
\hline P. caerulea & folhas & tetrafilina B & $\begin{array}{l}\text { Jaroszewski, } \\
\text { Fog (1989) }\end{array}$ \\
\hline P. capsularis & folhas, caules & passicapsina & $\begin{array}{l}\text { Fischer, Fung e } \\
\text { Lankhorst (1982) }\end{array}$ \\
\hline$P$. citrina & folhas, caules & passicapsina & $\begin{array}{l}\text { Jaroszewski et } \\
\text { al. (2002) }\end{array}$ \\
\hline$P$. coccinea & folhas & passicoccina & $\begin{array}{l}\text { Spencer, Seigler } \\
(1985)\end{array}$ \\
\hline P. coliinvauxii & folhas, caules & passibiflorina & $\begin{array}{l}\text { Andersen et al. } \\
(1993)\end{array}$ \\
\hline P. coriacea & folhas & $\begin{array}{l}\text { deidaclina, tetrafilina } A \text {, } \\
\text { tetrafilina } B \text {, } \\
\text { epivolquenina, } \\
\text { taractofilina }\end{array}$ & $\begin{array}{l}\text { Olafsdottir, } \\
\text { Andersen e } \\
\text { Jaroszewski } \\
(1989)\end{array}$ \\
\hline$P$. cuneata & folhas, caules & passibiflorina & $\begin{array}{l}\text { Jaroszewski et } \\
\text { al. }(2002)\end{array}$ \\
\hline P. edulis & folhas & prunasina & $\begin{array}{l}\text { Spencer, Seigler } \\
(1983)\end{array}$ \\
\hline P. edulis & folhas & $\begin{array}{l}\text { sambunigrina, } \\
\text { amidalina }\end{array}$ & $\begin{array}{l}\text { Chassagne et } \\
\text { al., (1996) }\end{array}$ \\
\hline
\end{tabular}


Tabela 3. Continuação

\begin{tabular}{|c|c|c|c|}
\hline Espécies & Órgãos & Substâncias & Referências \\
\hline P. edulis & frutos & $\begin{array}{l}\beta \text {-rutinosil- }(R)- \\
\text { mandelonitrila- } \alpha-L- \\
\text { ramnopiranosil- } \beta \text {-D- } \\
\text { glicopiranosideo }\end{array}$ & $\begin{array}{l}\text { Chassagne, } \\
\text { Crouzet (1998) }\end{array}$ \\
\hline P. foetida & sementes & $\begin{array}{l}\text { tetrafilina } A \text {, tetrafilina } \\
\text { B, sulfato de tetrafilina } \\
\text { B, deidaclina, } \\
\text { volquenina }\end{array}$ & $\begin{array}{l}\text { Andersen, } \\
\text { Adsersen e } \\
\text { Jaroszewski } \\
\text { (1998) } \\
\end{array}$ \\
\hline P. guatemalensis & folhas, caules & passiguatemalina & $\begin{array}{l}\text { Jaroszewski et } \\
\text { al. (2002) }\end{array}$ \\
\hline P. herbertiana & folhas, caules & $\begin{array}{l}\text { deidaclina, } \\
\text { epivolquenina, } \\
\text { taractofilina, tetrafilina }\end{array}$ & $\begin{array}{l}\text { Jaroszewski et } \\
\text { al., (2002) }\end{array}$ \\
\hline P. hybrida & folhas & tetrafilina B & $\begin{array}{l}\text { Jaroszewski, } \\
\text { Fog (1989) }\end{array}$ \\
\hline P. incarnata & folhas & ginocardina & $\begin{array}{l}\text { Spencer, Seigler } \\
\text { (1984) }\end{array}$ \\
\hline$P$. indecora & folhas, caules & passibiflorina & $\begin{array}{l}\text { Jaroszewski et } \\
\text { al. (2002) }\end{array}$ \\
\hline P. pendens & folhas & $\begin{array}{l}\text { linamarina, } \\
\text { lotaustraliana, } \\
\text { linustatina, } \\
\text { neolinustatina } \\
\end{array}$ & $\begin{array}{l}\text { Spencer, Seigler } \\
\text { e Nahrstedi } \\
\text { (1986) }\end{array}$ \\
\hline P. perfoliata & folhas & a-hidroxinitrila & $\begin{array}{l}\text { Fischer, Fung e } \\
\text { Lankhorst (1982) }\end{array}$ \\
\hline P. perfoliata & folhas & passibiflorina & $\begin{array}{l}\text { Jaroszewski et } \\
\text { al. }(2002)\end{array}$ \\
\hline P. quadrangularis & folhas & Tetrafilina B & $\begin{array}{l}\text { Jaroszewski, } \\
\text { Fog (1989) }\end{array}$ \\
\hline P. racemosa & folhas & Tetrafilina B & $\begin{array}{l}\text { Jaroszewski, } \\
\text { Fog (1989) }\end{array}$ \\
\hline P. talamancensis & folhas & $\begin{array}{l}\text { passibiflorina, } \\
\text { epipassibiflorina }\end{array}$ & $\begin{array}{l}\text { Spencer, Seigler } \\
\text { (1985) }\end{array}$ \\
\hline P. trifasciata & folhas & passitrifasciatina & $\begin{array}{l}\text { Spencer, Seigler } \\
\text { (1985) }\end{array}$ \\
\hline
\end{tabular}


Tabela 3. Continuação

\begin{tabular}{llll}
\hline Espécies & Órgãos & Substâncias & Referências \\
\hline$P$. trifasciata & folhas & passitrifasciatina & $\begin{array}{l}\text { Olafsdottir, } \\
\text { Jaroszewski e } \\
\text { Seigler (1991) }\end{array}$ \\
\hline$P$. warmingii & folhas & linamarina & $\begin{array}{l}\text { Fischer, Fung e } \\
\text { Lankhorst (1982) }\end{array}$ \\
\hline$P$. warmingii & folhas & linamarina & $\begin{array}{l}\text { Spencer, Seigler } \\
\text { e Nahrstedi } \\
\text { (1986) }\end{array}$ \\
\hline$P$. warmingii & folhas & epilotaustralina & $\begin{array}{l}\text { Olafsdottir, } \\
\text { Andersen e } \\
\text { Jaroszewski } \\
\text { (1989) }\end{array}$ \\
\hline
\end{tabular}

\subsubsection{Saponinas}

Saponinas são glicosídeos que produzem espuma persistente em solução aquosa. Algumas saponinas apresentam propriedades hemolíticas; no entanto, quando administradas por via oral são praticamente atóxicas (TREASE; EVANS, 1996; BRUNETON, 1999).

Possuem peso molecular e polaridade altos; seu isolamento, portanto, apresenta algumas dificuldades. Ocorrem comumente como misturas complexas, com os componentes diferindo quanto aos açúcares ou na estrutura da aglicona (HOSTETTMANN; MARSTON, 1995; BRUNETON, 1999).

A classificação das saponinas pode ser baseada no núcleo fundamental da aglicona, divididas basicamente em tripterpênicas e esteroidais. As saponinas esteroidais são encontradas principalmente em monocotiledôneas; as triterpênicas predominantemente em dicotiledôneas, nas famílias Sapindaceae, Sapotaceae, Polygonaceae, Caryophylaceae, Araliaceae (BRUNETON, 1999). Seu nome deriva de sapo (sabão, em latim) e refere-se à formação de espuma persistente que as saponinas exibem ao serem agitadas em soluções aquosas (HOSTETTMANN; MARSTON, 1995). 
Ainda pouco estudados no gênero, os glicosídeos triterpênicos foram sugeridos como responsáveis pela atividade sedativa das passifloras, sobretudo a passiflorina (Figura 6), isolada de $P$. edulis (HEGNAUER, 1990; BOMBARDELLI et al., 1975).

No gênero ocorrem glicosídeos triterpênicos (Figura 6, Tabela 4), tais como o quadrangulosídeo e o ácido 3-soforosil oleanólico, isolados de $P$. alata e $P$. quadrangularis (REGINATTO et al., 2001). Na literatura não consta o emprego destas substâncias em ensaios farmacológicos, até o presente. Reginatto e colaboradores (2004) relataram o teor de quadrangulosídeo nas folhas de $P$. alata de $0,8 \%$ em relação à droga vegetal.

$\mathrm{Na}$ literatura, dentre as atividades farmacológicas dos glicosídeos triterpênicos, encontram-se descritas a atividade sedativa e antiúlcera (HOSTETTMANN; MARSTON, 1995). 
<smiles>C/C(O)=C\CC[C@@H](CO)[C@H]1CCC2C3CCC4C(C)(C)[C@@H](O)CCC45CC35CC[C@]21C</smiles>

Quadrangulosídeo

$$
\mathrm{R}=\text { gentiobiose }
$$

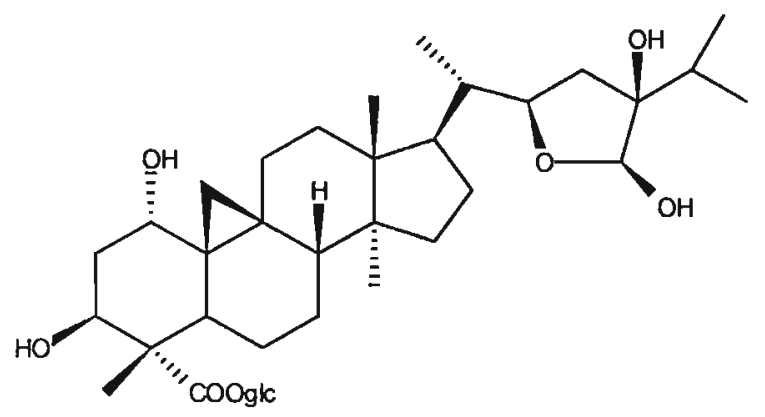<smiles>[R20]C1CC[C@]2(C)[C@@H]3CC=C4C5CC(C)(C)CC[C@]5(C(=O)O)CC[C@]4(C)[C@]3(C)CC[C@@H]2C1(C)C</smiles>

Ácido 3-soforosil oleanólico

$$
R=g \mid c(1-2) g l c
$$

Passiflorina

$$
\text { glc }=\text { glicose }
$$

Figura 6. Saponinas encontradas em espécies de Passiflora L. 
Tabela 4. Saponinas encontradas em espécies de Passiflora L.

\begin{tabular}{|c|c|c|c|}
\hline Espécies & Órgãos & Substâncias & Referências \\
\hline P. alata & folhas & $\begin{array}{l}\text { quadrangulosídeo, } \\
\text { ácido 3-soforosil } \\
\text { oleanólico }\end{array}$ & $\begin{array}{l}\text { Doyama et al. } \\
\text { (2005) }\end{array}$ \\
\hline P. calcarata & folhas & passiflorina & $\begin{array}{l}\text { Bombardelli et } \\
\text { al. (1975) }\end{array}$ \\
\hline P. edulis & folhas & passiflorina & $\begin{array}{l}\text { Bombardelli et } \\
\text { al. (1975) }\end{array}$ \\
\hline P. lechenaultii & folhas & passiflorina & $\begin{array}{l}\text { Bombardelli et } \\
\text { al. (1975) }\end{array}$ \\
\hline P. mollissima & folhas & passiflorina & $\begin{array}{l}\text { Bombardelli et } \\
\text { al. (1975) }\end{array}$ \\
\hline P. quadrangularis & folhas & quadrangulosídeo & $\begin{array}{l}\text { Orsini, Pelizzoni } \\
\text { e Verotta (1986) }\end{array}$ \\
\hline P. quadrangularis & folhas & $\begin{array}{l}\text { 22-hidroxi- } \\
\text { isoquadrangulosídeo }\end{array}$ & $\begin{array}{l}\text { Orsini, Verotta } \\
(1985)\end{array}$ \\
\hline P. quadrangularis & folhas & $\begin{array}{l}\text { ácido } 3-O-\beta-D- \\
\text { glicopiranosil-(1-2)- } \beta-D- \\
\text { glicopiranosil oleanólico }\end{array}$ & $\begin{array}{l}\text { Orsini, Verotta } \\
\text { (1985) }\end{array}$ \\
\hline P. quadrangularis & folhas & 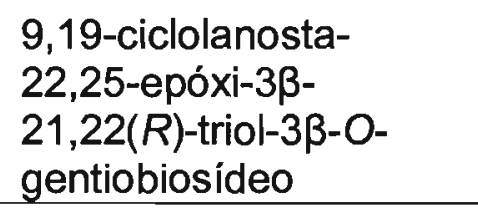 & $\begin{array}{l}\text { Orsini et al. } \\
(1987)\end{array}$ \\
\hline P. quadrangularis & folhas & 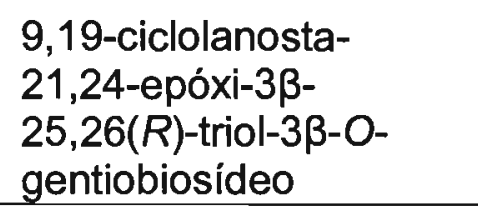 & $\begin{array}{l}\text { Orsini et al. } \\
(1987)\end{array}$ \\
\hline P. quadrangularis & folhas & $\begin{array}{l}\text { ácido 3-soforosil } \\
\text { oleanólico }\end{array}$ & $\begin{array}{l}\text { Orsini et al. } \\
(1987)\end{array}$ \\
\hline
\end{tabular}

\subsection{Atividades farmacológicas de espécies de Passiflora L.}

Grande parte dos estudos sobre o gênero relaciona-se ao isolamento e à elucidação da estrutura dos diversos compostos; poucos são os ensaios farmacológicos comparados aos estudos fitoquímicos. Acresce-se que os estudos 
farmacológicos do gênero dirigem-se às atividades no sistema nervoso central, destacando-se as atividades ansiolítica e sedativa.

A ação sedativa de $P$. incarnata foi registrada pela primeira vez por Phares, em 1867 (FREITAS, 1985). Desde 1875, consta a utilização da tintura-mãe desta espécie como sedativo em homeopatia (HALE, 1875).

A partir da década de trinta, diversos autores (FELLOWS; SMITH, 1938; RUGGY; SMITH, 1940) procuraram avaliar e por vezes, relacionar as atividades farmacológicas de extratos de Passiflora com as prováveis substâncias ativas. Durante algumas décadas os alcalóides foram investigados (NEU, 1956; LUTOMSKI, 1959). Posteriormente, os flavonóides tornaram-se o foco das atenções. No entanto, nenhuma investigação chegou em nível de mecanismo de ação das substâncias.

Fellows e Smith (1938) detectaram a diminuição da pressão arterial em cães com o extrato aquoso de $P$. incarnata. No entanto, segundo os autores, a substância ativa, solúvel em água, não se tratava de um alcalóide.

Borgatti (1939) descreveu atividade de paralisia do intestino de coelho e efeito espasmolítico periférico com o resíduo seco do extrato alcoólico de $P$. incarnata.

Ruggy e Smith (1940) isolaram uma substância, que chamaram de "o princípio fisiologicamente ativo" de $P$. incarnata. Os autores observaram que tanto 0 princípio ativo como o extrato fluido não apresentavam ação sedativa.

O princípio ativo causou hipotensão e cardiomegalia em cães, contração dos músculos lisos de intestino e útero de coelhos e porquinhos-da-índia. Estas atividades não foram afetadas por vagotomia e administração de atropina ou nicotina. Assim, os autores, sugeriram que a substância exerceria ação direta sobre os músculos lisos e descreveram que a sustância isolada não se tratava de um alcalóide, mas de um glicosídeo de natureza desconhecida (RUGGY; SMITH, 1940).

Apenas em 2000 encontra-se um estudo avaliando a atividade cardiovascular de alcalóides descritos em Passiflora. Shi e colaboradores (2000) estudaram o efeito cardiovascular in vivo e o efeito vasodilatador in vitro do alcalóide harmana. A substância, nas doses de 1 a $10 \mathrm{mg} / \mathrm{kg}$, administrado por via intravenosa, produziu hipotensão transiente e bradicardia de longa duração, de maneira dose-dependente, em ratos anestesiados com pentobarbital. 
Os autores sugerem que o efeito vasodilatador relaciona-se à liberação de óxido nítrico nas células endoteliais e nos músculos lisos vasculares, inibição das contrações induzidas pela ativação dos canais de cálcio, voltagem-dependentes e ligados a receptores. Segundo os autores, a atividade vasodilatadora pode estar envolvida no efeito hipotensor do alcalóide (SHI et al., 2000).

Neugebauer, em 1949, relacionou a atividade sedativa de extratos de $P$. incarnata, $P$. edulis e $P$. bryonioides à presença de uma substância de caráter básico, provavelmente um alcalóide (HEGNAUER, 1990). O autor acreditava que uma das substâncias estudadas por ele, obtida a partir de $P$. incarnata e com atividade sedativa em ratos, era idêntica à maracujina, isolada por Peckolt (1909) de extratos obtidos de espécies brasileiras de Passiflora, entre elas $P$. alata. Também sugeriu que a substância isolada deveria ser idêntica ao composto obtido por Ruggy e Smith (1940).

O mecanismo de ação sedativa dos alcalóides $\beta$-carbolínicos foi estudado por Rommelspacher e colaboradores em 1980. Os autores avaliaram a interação de diversos alcalóides deste grupo na ligação especifica de $\left[{ }^{3} \mathrm{H}\right]$-flunitrazepam com receptores benzodiazepínicos. O estudo foi realizado em membrana cerebral de rato e retina de bovinos, ambos contendo os referidos receptores. Dos compostos investigados, harmana e nor-harmana foram os inibidores mais potentes da ligação específica do $\left[{ }^{3} \mathrm{H}\right]$-flunitrazepam, com valores de $\mathrm{IC}_{50}$ em concentrações micromolares. Os outros derivados, tais como, harmina, harmalina e diversos tetraidro-derivados foram, no mínimo, dez vezes menos potentes (ROMMELSPACHER et al., 1980).

O alcalóide harmana, encontrado no cérebro de ratos e na urina humana, segundo os autores, era o mais potente inibidor conhecido da ligação específica do $\left[{ }^{3} \mathrm{H}\right]$-flunitrazepam. Sua afinidade com os receptores benzodiazepínicos mostrou-se centenas de vezes maior que a da inosina e da hipoxantina (que por sua vez possuem valores de $\mathrm{IC}_{50}$ na mesma concentração do L-triptofano e da triptamina). Assim, os autores sugerem que harmana, ou outros alcalóides $\beta$-carbolínicos, poderiam ser candidatos em potencial como ligantes endógenos do receptor benzodiazepínico (ROMMELSPACHER et al., 1980).

Aoyagi e colaboradores, durante a avaliação das atividades farmacológicas do extrato seco de $P$. incarnata, isolaram maltol (3-hidroxi-2-metil-4-pirona, Figura 7) 
da fração solúvel em ácido clorídrico, por sublimação sob pressão reduzida, com rendimento de $0,05 \%$ (AOYAGI; KIMURA; MURATA, 1974). Os autores avaliaram as atividades farmacológicas do extrato seco, da sua fração solúvel em ácido clorídrico, do maltol e do etilmaltol (sintético). A fração diminuiu o consumo de oxigênio do córtex de ratos em altas concentrações. O maltol causou depressão nos ratos, potenciação de sono induzido por hexobarbital, atividade anticonvulsivante e inibição da atividade motora. O etilmaltol mostrou efeitos similares ao maltol, porém, atividade anticonvulsivante mais potente e menor inibição da atividade motora espontânea.

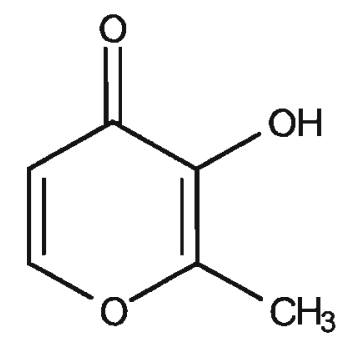

Figura 7. Maltol, encontrado na espécie Passiflora incarnata L.

O extrato fluido de órgãos aéreos de $P$. incarnata, administrado por via oral e intraperitoneal em ratos, aumentou o limiar nociceptivo no teste de tail-flick e de placas quentes. Administrado por via intraperitoneal, o extrato prolongou significativamente o tempo de sono, protegeu os animais do efeito convulsivo do pentilenotetrazol e afetou a locomoção. $O$ extrato, particionado por solventes e métodos cromatográficos, encerrava pelo menos dois produtos ativos, um lipofilico e outro hidrofílico; no entanto, estes compostos não se tratavam dos flavonóides ou alcalóides presentes no extrato. Além disso, o composto lipofílico não pareceu corresponder a uma estrutura aromática ou heterocíclica (SPERONI; MINGHETTI, 1988).

Segundo os mesmos autores (SPERONI; MINGHETTI, 1988), o efeito antinociceptivo foi atribuído à deficiência motora induzida pelo extrato, uma vez que 
o extrato afetou a atividade locomotora e o tempo de sono induzido por pentetrazol de forma significativa.

Maluf e colaboradores (1991), investigando os efeitos hipnótico e sedativo do extrato aquoso obtido de folhas de $P$. edulis em camundongos, ratos e seres humanos, observaram efeito depressor não específico, porém, nenhum efeito hipnótico-sedativo. Trata-se de um dos poucos estudos que coloca em dúvida a atividade da espécie.

Santos e colaboradores (2005) investigaram a ação sedativa de extratos e frações de $P$. actinia Hooker. Tal efeito não pôde ser relacionado a nenhum grupo de substâncias.

A partir da década de noventa, os autores (WOLFMAN et al., 1994; RUGGY; SOULIMANI et al., 1997) procuraram relacionar as atividades farmacológicas observadas com extratos de Passiflora aos flavonóides, que em pouco tempo tornaram-se o novo foco das atenções.

Zanoli e colaboradores (2000) estudaram os efeitos comportamentais da administração aguda de apigenina e crisina em ratos. Os autores observaram que os dois flavonóides foram igualmente capazes de reduzir a atividade locomotora, quando administrados por via oral em uma dose de $25 \mathrm{mg} / \mathrm{kg}$. No entanto, enquanto a crisina exibiu um efeito claramente ansiolítico com uma dose de $1 \mathrm{mg} / \mathrm{kg}$, a apigenina não exibiu a atividade com a mesma dose. $O$ efeito sedativo destes flavonóides não pôde ser atribuído a uma interação com os receptores GABAbenzodiazepínicos, pois 0 efeito não foi bloqueado pelo antagonista benzodiazepínico flumazenil.

O flavonóide crisina, isolado de $P$. caerulea, foi descrito como um agonista parcial dos receptores benzodiazepínicos, por demonstrar ação ansiolítica sem indução de sedação ou de relaxamento muscular (WOLFMAN et al., 1994).

Soulimani e colaboradores (1997), utilizando extratos hidroalcoólicos liofilizados e aquosos de órgãos aéreos de $P$. incarnata, verificaram efeitos comportamentais em camundongos. Segundo os autores, o extrato hidroalcoólico apresentou atividade ansiolítica com $400 \mathrm{mg} / \mathrm{kg}$ e o extrato aquoso apresentou atividade sedativa com $400 \mathrm{mg} / \mathrm{kg}$. 
Apesar dos diversos estudos, ainda não estão definidas as substâncias responsáveis pela atividade ansiolitica ou sedativa atribuídas às passifloras (PETRY et al., 2001; REGINATTO et al., 2004).

O extrato etanólico de órgãos aéreos de $P$. incarnata foi testado inclusive quanto à atividade antiinflamatória em ratos, administrado por via oral. Foi observada atividade significativa com dose de 125 a $500 \mathrm{mg} / \mathrm{kg}$. Porém, não se pôde precisar o envolvimento de mediadores endógenos na atividade antiinflamatória e a natureza química dos compostos do extrato, responsáveis pela atividade (BORRELLI et al., 1996). No entanto, o efeito observado em $P$. incarnata foi relativamente baixo, se comparado ao efeito exibido nos mesmos ensaios pelo fármaco de referência utilizado, o ácido acetilsalicilico.

Uma revisão sob os aspectos fitoquímicos e farmacológicos das espécies tema desta dissertação, $P$. alata e $P$. nitida, são apresentados nos itens seguintes (2.4., p. 33 e 2.5., p. 36).

\subsection{Passiflora alata Curtis}

Passiflora alata (Figura 8A) e $P$. edulis, são as únicas espécies de maracujá que atingem escala de mercado, como frutífera, no Brasil (MELETTI; MAIA, 1999; BERNACCI, 2003). Segundo Souza e Meletti (1997), $P$. alata é cultivada em escala comercial, especialmente no Estado de São Paulo e seu fruto é apreciado para consumo in natura e no preparo de refrescos e sorvetes. No entanto, é virtualmente inexistente o uso no Brasil de $P$. alata, assim como de outras espécies de maracujá, com a finalidade exclusiva de ornamentação (PEIXOTO, 2005).

Nativa do Brasil, $P$. alata ocorre principalmente em capoeiras e restingas litorâneas, mas raramente em orlas de florestas (CERVI, 1997). É encontrada silvestre em todas as regiões do país e, segundo Souza e Meletti (1997), ocorre nos Estados de Mato Grosso do Sul, Bahia, Minas Gerais, Rio de Janeiro, São Paulo, Paraná e Santa Catarina; ocorre também na Argentina, no Paraguai e no Peru (BRAGA et al., 2005). 
Em Santa Catarina, floresce e frutifica de setembro a abril (SACCO, 1980); em São Paulo, floresce o ano todo nas condições de Jaboticabal (FERREIRA; OLIVEIRA, 1991) e na região sudeste, o florescimento ocorre durante todo o ano, apresentando picos de abundância no verão e de escassez no inverno (VASCONCELLOS et al., 1994). Segundo Souza e Meletti (1997), o florescimento ocorre no Brasil, de modo geral, de setembro a abril.

Além disso, $P$. alata é resistente ao percevejo, ao besouro e à lagarta e, suscetível à bacteriose, à antracnose, à cladosporiose, à mosca-das-frutas e ao vírus do endurecimento dos frutos (BRAGA et al., 2005).

A espécie destaca-se pelo emprego em diversas preparações farmacêuticas registradas no Brasil pela Agência Nacional de Vigilância Sanitária (BRASIL, 2006).

A Farmacopéia Brasileira, em três de suas quatro edições (SILVA, 1929; FARMACOPÉIA DOS ESTADOS UNIDOS DO BRASIL, 1959; FARMACOPÉIA BRASILEIRA, 1977), oficializou as folhas de $P$. alata, sob a designação de "maracujá".

No entanto, existem poucos estudos fitoquímicos e farmacológicos relacionados a essa espécie vegetal (ULUBELEN; OKSUZ; MABRY, 1982; OGA et al., 1984; PETRY et al., 2001).

Um dos primeiros estudos fitoquímicos com $P$. alata foi realizado por Ulubelen e colaboradores (1982), que identificaram flavonóides C-glicosídeos: 2"xilosilvitexina, vitexina, isovitexina e orientina.

Pesquisadores brasileiros (OGA et al., 1984; PETRY et al., 2001; REGINATTO et al., 2001; DOYAMA et al., 2005), sobretudo, têm se dedicado ao estudo farmacológico e fitoquímico de folhas de $P$. alata.

No estudo conduzido por Oga e colaboradores (1984), o extrato seco de folhas de $P$. alata, administrado a camundongos, por via intraperitoneal, reduziu a atividade motora espontânea dos animais e prolongou o tempo de sono induzido por pentobarbital em doses de 75 e $150 \mathrm{mg} / \mathrm{kg}$. Além disso, o extrato apresentou atividade anticonvulsivante em convulsões induzidas por pentilenotetrazol, aumentando tanto o tempo de latência quanto o tempo de sobrevida dos animais, com doses de 75 e $150 \mathrm{mg} / \mathrm{kg}$; com $150 \mathrm{mg} / \mathrm{kg}$, o extrato reduziu a letalidade para $83,3 \%$, enquanto diazepam, o fármaco de referência, reduziu-a para $66,6 \%$. O valor 
da $\mathrm{DL}_{50}$ do extrato foi estimado como $456 \mathrm{mg} / \mathrm{kg}$. O extrato não apresentou efeito analgésico nas concentrações testadas, mesmo com $150 \mathrm{mg} / \mathrm{kg}$. O extrato apresentou $0,217 \mu \mathrm{g} / \mathrm{kg}$ de alcalóides $\beta$-carbolínicos, expressos como harmana e $44,8 \mu \mathrm{g} / \mathrm{kg}$ de derivados flavonoídicos. A presença de vitexina, isovitexina e isoorientina foi detectada por cromatografia em camada delgada.

A atividade ansiolítica de extratos hidroetanólicos a $40 \%$, obtidos de folhas de $P$. alata foi avaliada, após evaporação do etanol e administração por via intraperitoneal, através do teste de labirinto em cruz elevado. Os extratos demonstraram atividade em doses de 100 e $150 \mathrm{mg} / \mathrm{kg}$ (PETRY et al., 2001).

Reginatto e colaboradores (2001) identificaram em folhas de $P$. alata quatro glicosídeos triterpênicos e um glicosídeo esteroidal. Dentre estes, o mais abundante na espécie é o quadrangulosídeo, com teor de $0,8 \%$ em relação às folhas secas (REGINATTO et al., 2004); substância previamente identificada em $P$. quadrangularis por Orsini e colaboradores (1986).

De-Paris e colaboradores (2002) investigaram o extrato aquoso das folhas de $P$. alata e descreveram efeito ansiolítico em ratos com doses de 100 e $150 \mathrm{mg} / \mathrm{kg}$.

Doyama e colaboradores (2005) identificaram na mesma espécie, o quadrangulosídeo e o ácido 3-soforosil oleanólico, anteriormente descritos por Reginatto e colaboradores (2001), além dos flavonóides isovitexina, isoorientina, 2"O-ramnosil-vitexina, 2"-O-ramnosil-orientina e 2"-O-rarnnosil-escoparina.

Adicionalmente, os mesmos autores (DOYAMA et al., 2005) relataram que o extrato aquoso, administrado por via oral, alterou o metabolismo lipídico em ratos, aumentando o teor de proteinas de alta densidade no sangue (HDL, high-density lipoprotein) com uma dose de $1000 \mathrm{mg} / \mathrm{kg}$. 


\subsection{Passiflora nitida Kunth}

Passiflora nitida Kunth (Figura 8B), espécie conhecida como maracujá-suspiro ou maracujá-do-mato, é nativa da região Amazônica e está bem adaptada ao Estado de São Paulo (MORAES et al., 2002; BERNACCI, 2003; FELIPPE; TOMASI, 2005). A espécie havia sido pouco estudada sob o ponto de vista fitoquímico ou farmacológico até o presente.

A espécie vegetal é resistente a Xanthomonas, gênero de bactérias conhecidas por infectar plantas, mas suscetível ao vírus do endurecimento dos frutos (MORAES et al., 2002). Foi encontrada referência de uso popular da espécie como antimicrobiano e em distúrbios gastrintestinais.
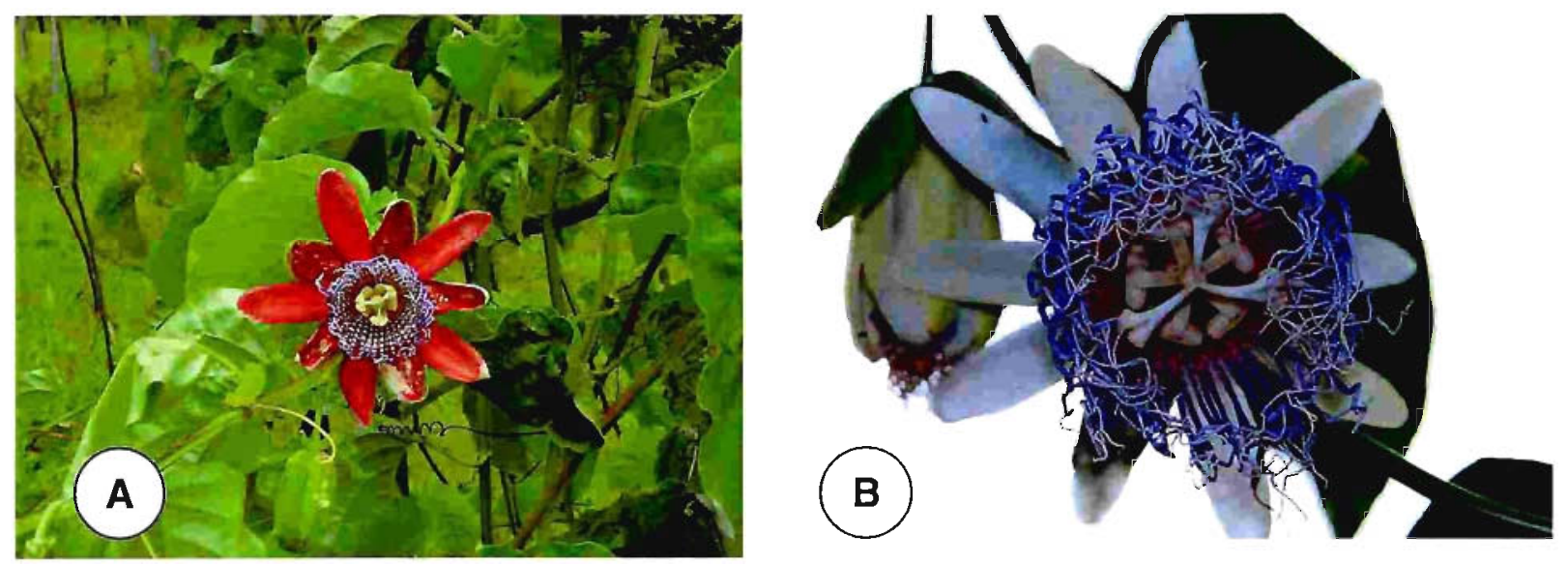

Figura 8. Ramos floridos de (A) Passiflora alata Curtis e (B) P. nitida Kunth. 


\section{Objetivos}

É objetivo da dissertação realizar o estudo farmacognóstico comparativo de Passiflora alata Curtis e $P$. nitida Kunth, através de:

$\Rightarrow$ descrição macroscópica e microscópica das folhas e dos caules das espécies;

$\Rightarrow$ preparo de extratos liofilizados em condições padronizadas;

$\Rightarrow$ triagem fitoquímica, para a caracterização de classes de compostos e o estabelecimento do perfil cromatográfico dos extratos liofilizados;

$\Rightarrow$ avaliação das atividades antioxidante e antiúlcera dos extratos liofilizados;

$\Rightarrow$ quantificação do provável grupo de substâncias ativas presentes nos extratos liofilizados. 


\section{Material e métodos}

\subsection{Material vegetal}

Os órgãos aéreos de Passiflora alata Curtis e de $P$. nitida Kunth, empregados no estudo, foram coletados na reserva do Instituto Agronômico de Campinas, localizada em Monte Alegre do Sul, no Estado de São Paulo. P. alata foi coletada em fevereiro de 2006 e $P$. nitida em novembro de 2005. As espécies foram identificadas por Luis Carlos Bernacci, pesquisador do referido Instituto e exsicatas referência do estudo foram confeccionadas e estão depositadas no Herbário do Instituto de Biociências da Universidade de São Paulo, sob as designações de VM01 e AW01, respectivamente. Abaixo segue o esquema de obtenção das drogas vegetais e dos estudos subseqüentes (Figura 9).

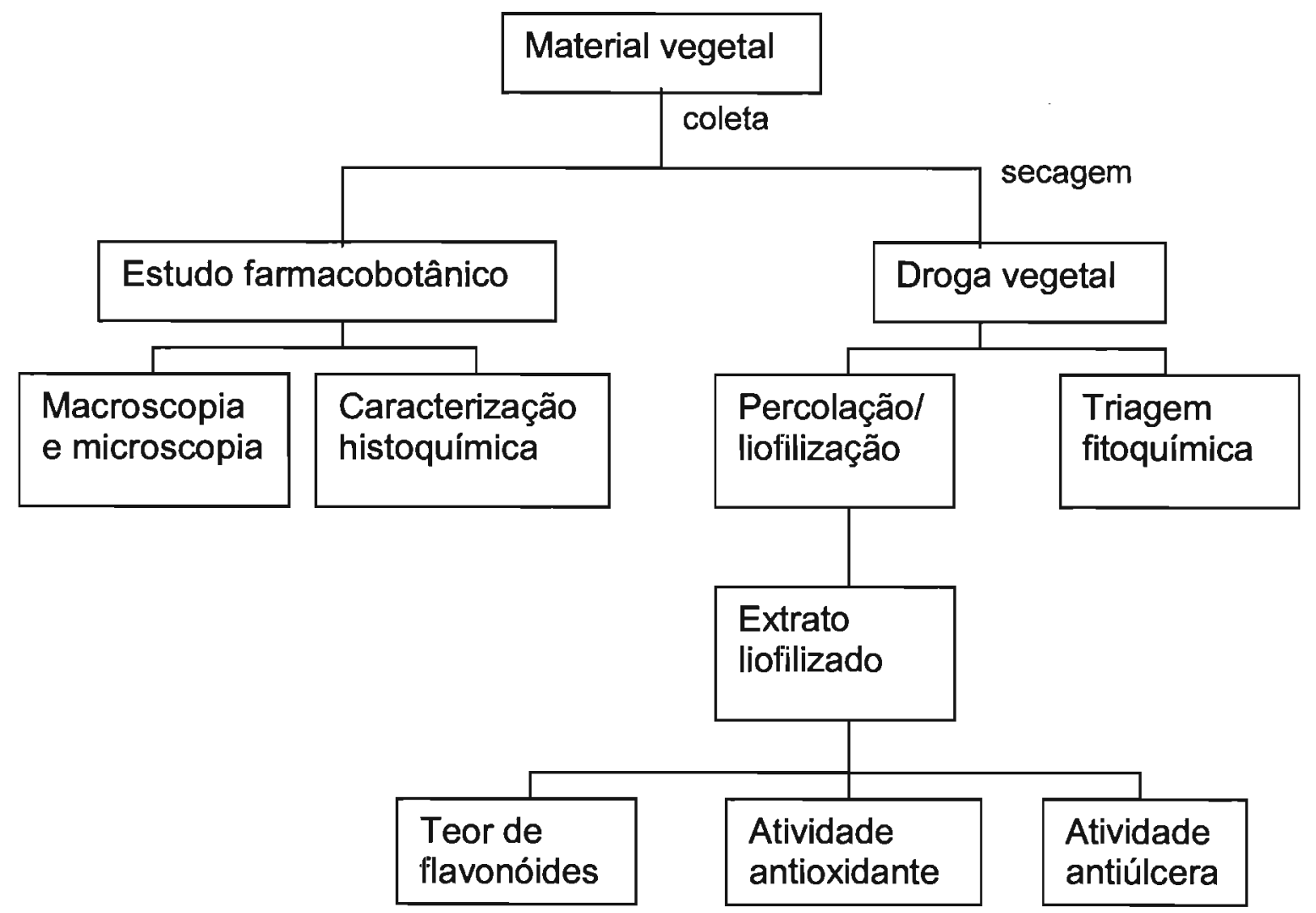

Figura 9. Esquema de obtenção das drogas vegetais (Passiflora alata e $P$. nitida) e estudos subseqüentes. 


\subsection{Estudo farmacobotânico}

No estudo da morfologia das drogas vegetais, constituída de folhas e de caules de $P$. alata e $P$. nitida, desidratados em estufa, foram analisados filotaxia, forma da folha e do caule, nervação, tipo de indumento, tamanho, caracteres organolépticos e peculiaridades. Os materiais foram observados com auxílio de lupa estereoscópica Leica ${ }^{\circledR}$, modelo MZ8. A terminologia empregada na descrição das espécies seguiu a sugerida por Radford (1986).

Para as dimensões encontradas foram determinados os valores médio, máximo, mínimo, desvio padrão e coeficiente de variação (PEREIRA et al., 2002), sendo o grupo considerado uniforme para $p<0,05$.

A caracterização microscópica de cada uma das amostras foi realizada em cortes preparados com material fresco ou em material fixado em solução de FAA 70 (formaldeído, ácido acético e etanol $70 \%$ ) e conservado em solução de etanol $70 \%$ (v/v) (BERLYN; MIKSCHE, 1976).

As secções transversais e longitudinais foram efetuadas no terço mediano inferior da lâmina foliar plenamente desenvolvida. Os cortes do pecíolo foram efetuados na porção proximal, mediana e distal à lâmina foliar.

Inicialmente, as secções foram diafanizadas com solução de hipoclorito de sódio a $50 \%(\mathrm{v} / \mathrm{v})$. Após lavagem com água destilada, foram corados com safranina $0,1 \%$ (em etanol $50 \%$ ) e azul de Astra (ROESER, 1962).

Macerações cuticulares e dissociações de folhas e caules foram realizadas. $O$ material utilizado foi mantido a $60^{\circ} \mathrm{C}$, por 12 horas, em volumes iguais de peróxido de hidrogênio $20 \%$, e ácido acético glacial (FRANKLIN, 1945). Os materiais obtidos, após lavagem, foram corados com safranina e azul de Astra.

Nos testes histoquímicos foram empregados: floroglucina clorídrica, para elementos lignificados (SASS, 1951), Sudam III para substâncias lipofílicas (FOSTER, 1949), cloreto férrico 2\% (JOHANSEN, 1940) para compostos fenólicos e lugol (BERLYN; MIKSCHE, 1976) para amiloplastos.

$\mathrm{Na}$ obtenção das preparações semipermanentes, os cortes foram corados com soluções de azul de Astra e safranina e os resultados obtidos registrados com 
auxílio de um fotomicroscópio Leica ${ }^{\circledR}$, modelo DMLB. As escalas foram obtidas nas mesmas condições.

\subsection{Preparo do extrato hidroetanólico liofilizado}

Cada uma das drogas vegetais foi pulverizada em moinho de facas e martelos de marca Thomas ${ }^{\circledR}$. O extrato hidroetanólico, foi preparado pelo processo geral de percolação (FARMACOPÉIA BRASILEIRA, 1988) utilizando solução hidroetanólica a $60^{\circ} \mathrm{GL}$.

Esta solução hidroetanólica foi concentrada em evaporador rotativo Bücchi ${ }^{\circledR}$ a $45-50^{\circ} \mathrm{C}$ até a evaporação do etanol. A água residual foi liofilizada, em aparelho de marca Edwards ${ }^{\circledR}$. O extrato liofilizado foi empregado na triagem fitoquímica e nos ensaios farmacológicos.

\subsection{Triagem fitoquímica}

Todos os reagentes e solventes empregados apresentavam grau PA.

\subsubsection{Flavonóides}

\subsubsection{Extração}

Um grama de droga vegetal pulverizada de cada uma das amostras foi extraído com $10 \mathrm{~mL}$ de metanol por 5 minutos sob refluxo a $60{ }^{\circ} \mathrm{C}$ e filtrado (WAGNER; BLADT, 1996).

Cinco mililitros de extrato metanólico foram concentrados até cerca de $2 \mathrm{~mL}$. A seguir, foram adicionados $1 \mathrm{~mL}$ de água e $10 \mathrm{~mL}$ de acetato de etila. $O$ conjunto foi submetido à agitação em funil de separação. A fração acetato de etila foi 
separada e seu volume reduzido a $1 \mathrm{~mL}$. Na cromatoplaca foram aplicados $10 \mu \mathrm{L}$ de cada um dos extratos.

Os extratos liofilizados preparados com cada uma das drogas vegetais (item 4.3., p. 40) também foram utilizados. Dez microlitros de cada uma das soluções a $1 \%$ em metanol foram aplicados nas cromatoplacas.

\subsubsection{Sistema cromatográfico}

O sistema empregado na análise cromatográfica comparativa em camada delgada da fração flavonoídica das drogas vegetais e dos extratos liofilizados constituiu-se de:

$\Rightarrow$ Adsorvente: Sílica $60 \mathrm{GF}_{254}$ em placa de vidro;

$\Rightarrow$ Espessura da camada: $0,25 \mathrm{~mm}$;

$\Rightarrow$ Ativação: por aquecimento a $105-110^{\circ} \mathrm{C}$ por uma hora;

$\Rightarrow$ Cuba: de vidro com saturação total;

$\Rightarrow$ Desenvolvimento: simples, ascendente;

$\Rightarrow$ Percurso: $10 \mathrm{~cm}$;

$\Rightarrow$ Fase móvel: Acetato de etila - ácido fórmico - ácido acético glacial - água (100:11:11:26; WAGNER; BLADT, 1996);

$\Rightarrow$ Substância de referência: rutina $0,05 \%$ em metanol (EUROPEAN PHARMACOPOEIA, 2005); quantidade aplicada: $10 \mu \mathrm{L}$.

$\Rightarrow$ Visualização: a cromatoplaca foi nebulizada com solução de difenil borato de 2-aminoetila a $1 \%$ em metanol - NP (Natural products reagent) e observada sob lâmpada de UV a 254 e 365 nm (WAGNER; BLADT, 1996). 


\subsubsection{Alcalóides}

\subsubsection{Extração}

A $1 \mathrm{~g}$ de droga vegetal pulverizada foram adicionados $1 \mathrm{~mL}$ de hidróxido de amônio a $10 \%$ e $10 \mathrm{~mL}$ de metanol e, submetidos a aquecimento por 30 minutos, sob refluxo. O extrato metanólico filtrado foi concentrado em evaporador rotativo até secura. $\mathrm{O}$ resíduo foi retomado em $1 \mathrm{~mL}$ de metanol; $10 \mu \mathrm{L}$ foram aplicados na cromatoplaca (WAGNER; BLADT, 1996).

Os extratos liofilizados obtidos das drogas vegetais (item 4.3., p. 40) também foram utilizados. Dez microlitros de cada uma das soluções a 1\% em metanol foram aplicados nas cromatoplacas.

\subsubsection{Sistema cromatográfico}

O sistema empregado na análise cromatográfica cornparativa em camada delgada da fração alcaloídica das drogas vegetais e dos extratos liofilizados constituiu-se de:

$\Rightarrow$ Adsorvente: Silica $60 \mathrm{GF}_{254}$ em placa de vidro;

$\Rightarrow$ Espessura da camada: $0,25 \mathrm{~mm}$;

$\Rightarrow$ Ativação: por aquecimento a $105-110^{\circ} \mathrm{C}$ por uma hora;

$\Rightarrow$ Cuba: de vidro com saturação total;

$\Rightarrow$ Desenvolvimento: simples, ascendente;

$\Rightarrow$ Percurso: $10 \mathrm{~cm}$;

$\Rightarrow$ Fase móvel: Clorofórmio - metanol (9:1; FREITAS, 1985);

$\Rightarrow$ Substância de referência: harmana 0,01\% em metanol; quantidade aplicada: $10 \mu \mathrm{L}$ (FREITAS, 1985). 
$\Rightarrow$ Visualização: a cromatoplaca foi observada sob luz UV, a $365 \mathrm{~nm}$, sem aplicação de solução reveladora (FREITAS, 1985).

\subsubsection{Saponinas}

\subsubsection{Extração}

A 0,5 g de droga vegetal pulverizada de cada uma das amostras, exatamente pesados, foram adicionados $20 \mathrm{~mL}$ de água destilada, seguindo-se fervura por 2 minutos.

O extrato aquoso foi, em seguida, decantado e filtrado para um balão volumétrico de $50 \mathrm{~mL}$.

Utilizando igual procedimento foram realizadas novas extrações com porções de $10 \mathrm{~mL}$ de água destilada. Os extratos aquosos foram filtrados para balão volumétrico até completar o volume.

Os extratos liofilizados obtidos das drogas vegetais (item 4.3., p. 40) também foram utilizados, após ressuspensão em água, nas mesmas proporções.

Solução de saponina Merck ${ }^{\circledast} 0,1 \%$ em água $(\mathrm{m} / \mathrm{v})$ foi utilizada como referência (WHO, 1998).

\subsubsection{2. Índice de espuma}

A presença ou a ausência de saponinas foi avaliada, de forma preliminar, pela agitação dos extratos preparados anteriormente em água (item 4.4.3.1., p. 43). As amostras que apresentaram espuma persistente foram empregadas na determinação do índice de espuma.

Foram numerados 10 tubos de ensaio de dimensões semelhantes. Cinco mililitros de água destilada foram colocados em todos os tubos, exceto no primeiro. 
Cinco mililitros dos extratos foram adicionados no primeiro e no segundo tubos e o conteúdo foi homogeneizado.

Cinco mililitros da solução do segundo tubo foram transferidos para o terceiro tubo, misturando-se bem. O processo foi repetido, em seqüência, até o décimo tubo, empregando-se a mesma pipeta volumétrica. Cinco $\mathrm{mL}$ da solução do último tubo foram desprezados.

Em seguida, todos os tubos foram agitados vigorosamente, no sentido longitudinal, durante 15 segundos. O conjunto permaneceu em repouso durante 15 minutos e foi observado qual dos tubos apresentava uma camada de espuma persistente de $1 \mathrm{~cm}$ (WHO, 1998).

\subsubsection{3. Índice de hemólise}

Os extratos aquosos preparados anteriormente (item 4.4.3.1., p. 43) foram avaliados quanto à atividade hemolítica.

A $20 \mathrm{~mL}$ de cada um dos extratos aquosos foram adicionados $180 \mathrm{mg}$ de cloreto de sódio.

Em 10 tubos de ensaio numerados foram colocados $20 \mathrm{~mL}$ de solução fișiológica, exceto no primeiro. Em seguida, foram adicionados $2 \mathrm{~mL}$ de cada um dos extratos aquosos isotonizados no primeiro e segundo tubos. A solução do segundo tubo foi homogeneizada e $2 \mathrm{~mL}$ do seu conteúdo foram transferidos para o terceiro tubo, seguindo-se homogeneização. $O$ processo de diluição seqüencial continuou até o décimo tubo de ensaio e $2 \mathrm{~mL}$ da última solução foram desprezados.

Ao final, $2 \mathrm{~mL}$ de uma suspensão de sangue bovino desfibrinado a $2 \% \mathrm{em}$ solução fisiológica foram adicionados a todos os tubos e o conteúdo dos mesmos foi homogeneizado (WHO, 1998).

As soluções dos tubos permaneceram em repouso por 1 hora e foi observada a maior diluição ainda capaz de provocar hemólise total. 


\subsection{Flavonóides Totais}

A Farmacopéia Européia utiliza, para o controle de qualidade de $P$. incarnata L., o ensaio espectrofotométrico de quantificação dos flavonóides $C$-glicosídeos, presentes na droga vegetal e calculados como vitexina. $O$ ensaio envolve uma complexação com reagente oxalo-bórico (EUROPEAN PHARMACOPOEIA, 2005).

\subsubsection{Ensaio}

\subsubsection{Solução $A$}

Em um Erlenmeyer de $125 \mathrm{~mL}$ de fundo chato foi preparada uma solução contendo $10 \mathrm{~mL}$ de metanol e $100 \mathrm{~mL}$ de ácido acético glacial.

\subsubsection{Solução B}

Em um balão volumétrico de $100 \mathrm{~mL}$ foi preparada uma solução contendo $0,25 \mathrm{~g}$ de ácido bórico e $0,2 \mathrm{~g}$ de ácido oxálico em $100 \mathrm{~mL}$ de ácido fórmico.

\subsubsection{Solução mãe}

Em um balão de $100 \mathrm{~mL}$ de fundo redondo foram introduzidos $0,200 \mathrm{~g}$ de cada uma das drogas vegetais pulverizadas e $40 \mathrm{~mL}$ de etanol $60 \%(\mathrm{v} / \mathrm{v})$. O conjunto foi aquecido em banho-maria a $60^{\circ} \mathrm{C}$ sob refluxo por 30 minutos. Após resfriamento, a solução foi filtrada por algodão para um balão de $100 \mathrm{~mL}$ de fundo chato. $\mathrm{O}$ algodão, com o resíduo da droga vegetal, foi transferido para o balão de $100 \mathrm{~mL}$ de fundo redondo e foram adicionados $40 \mathrm{~mL}$ de etanol $60 \%(\mathrm{v} / \mathrm{v})$. $O$ balão foi novamente aquecido em banho-maria a $60{ }^{\circ} \mathrm{C}$ sob refluxo, por 10 minutos. Após resfriamento, as duas soluções foram reunidas e filtradas por papel de filtro para um 
balão volumétrico de $100 \mathrm{~mL}$. A solução final foi diluída para $100 \mathrm{~mL}$ com o mesmo solvente (etanol $60 \%$ ).

Os extratos liofilizados obtidos de cada uma das drogas vegetais (item 4.3., p. 40) também foram utilizados, após ressuspensão em etanol $60 \%$, nas mesmas condições.

\subsubsection{Solução teste}

Cinco $\mathrm{mL}$ da solução mãe foram introduzidos em um balão de fundo redondo e evaporados até a secura em evaporador rotativo sob pressão reduzida. Ao resíduo solubilizado com $10 \mathrm{~mL}$ da solução $A$, foram adicionados $10 \mathrm{~mL}$ da solução $B$. Esta solução foi transferida para um balão volumétrico de $25 \mathrm{~mL}$ e o volume foi completado com ácido acético glacial.

\subsubsection{Solução de compensação}

Cinco $\mathrm{mL}$ da solução mãe foram introduzidos em um balão de fundo redondo e evaporados até a secura em evaporador rotativo sob pressão reduzida. Ao resíduo solubilizado com $10 \mathrm{~mL}$ da solução $A$, foram adicionados $10 \mathrm{~mL}$ de ácido fórmico. Esta solução foi transferida para um balão volumétrico de $25 \mathrm{~mL}$ e o volume foi completado com ácido acético glacial.

\subsubsection{Leitura}

A absorbância da solução teste foi medida após 30 minutos, por comparação com a solução de compensação, em $401 \mathrm{~nm}$. As leituras foram realizadas em triplicata e três leituras foram realizadas em períodos distintos. Os resultados foram expressos como média \pm desvio padrão. As leituras foram realizadas em espectrofotômetro UV-VIS Incibrás MF 200. 


\subsubsection{Cálculo}

O teor percentual de flavonóides totais, expresso como vitexina, foi calculado através da seguinte expressão:

$$
\text { Teor de flavonóides }=\frac{A \times 0,8}{m}
$$

$\Rightarrow A=$ absorbância da solução teste em $401 \mathrm{~nm}$;

$\Rightarrow m=$ massa da droga vegetal ou do extrato liofilizado, em gramas.

\subsection{Atividade antioxidante}

\subsubsection{Ensaio do DPPH}

O radical 2,2-difenil-1-picril hidrazila (DPPH, Figura 10) é um radical livre estável à temperatura ambiente que produz uma solução violácea em etanol. Em presença de substâncias antioxidantes o DPPH é reduzido e a solução etanólica torna-se incolor (MENSOR et al., 2001). A capacidade dos extratos vegetais liofilizados de reduzir o radical livre DPPH foi avaliada nos ensaios através da perda da coloração das soluções. O padrão utilizado nos ensaios foi a rutina. 
<smiles>O=[N+]([O-])c1cc([N+](=O)[O-])c(N(c2ccccc2)N(c2ccccc2)c2ccccc2)c([N+](=O)[O-])c1</smiles>

DPPH radical

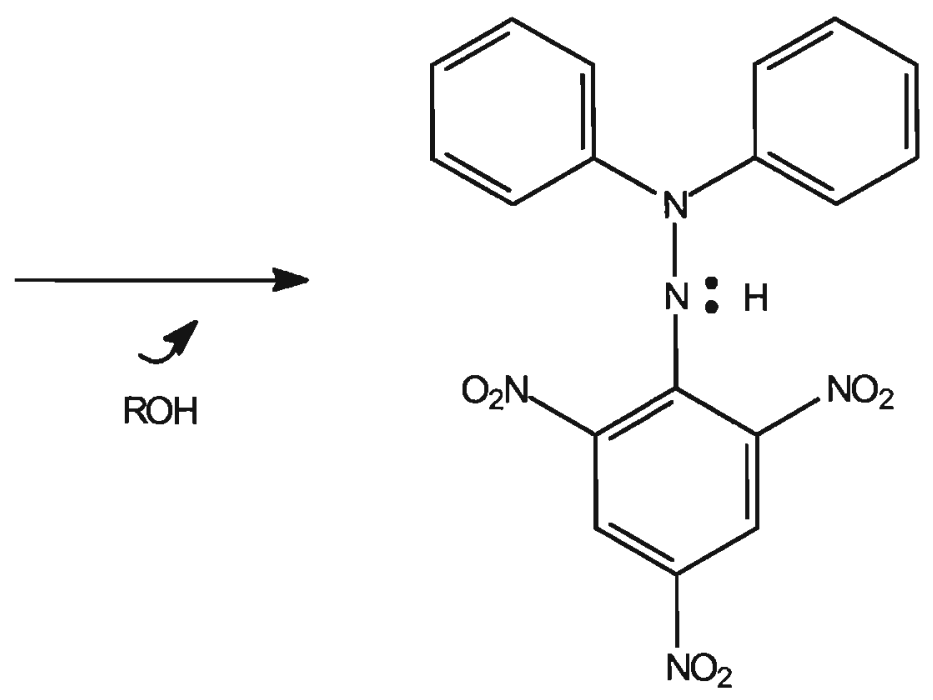

DPPH reduzido

Figura 10. Esquema de redução do radical 2,2-difenil-1-picril hidrazila (DPPH) por compostos fenólicos (ROH).

\subsubsection{Solução mãe}

Duzentos miligramas do extrato liofilizado de $P$. alata e $100 \mathrm{mg}$ do extrato liofilizado de $P$. nitida foram solubilizados em $100 \mathrm{~mL}$ de etanol, compondo soluções em concentrações de 2,0 e 1,0 mg/mL, respectivamente.

\subsubsection{Solução de rutina}

A rutina, empregada como substância de referência, foi solubilizada em etanol e diluída para concentrações de 3,$125 ; 6,25 ; 12,5 ; 25$ e $50 \mu \mathrm{g} / \mathrm{mL}$. 


\subsubsection{Solução teste}

A solução mãe dos extratos de $P$. alata e $P$. nitida foram diluídas em etanol, para concentrações de 0,$125 ; 0,25 ; 0,5 ; 1,0$ e $2,0 \mathrm{mg} / \mathrm{mL}$ e 31,$25 ; 62,5 ; 125 ; 250$ e $500 \mu \mathrm{g} / \mathrm{mL}$, respectivamente. Um mililitro da solução de DPPH foi adicionado a 2,5 $\mathrm{mL}$ das diferentes concentrações das soluções dos extratos e de rutina. A solução de DPPH Sigma ${ }^{\circledR}$ a $0,3 \mathrm{mmol} / \mathrm{L}$ foi preparada em etanol.

\subsubsection{Controle}

Uma solução contendo $1 \mathrm{~mL}$ da solução de DPPH e $2,5 \mathrm{~mL}$ de etanol foi utilizada como controle negativo. O controle positivo empregado foi a solução de rutina (item 4.6 .1 .2 , p. 48 ).

\section{4,6.1.5. Branco}

Soluções contendo $1 \mathrm{~mL}$ de etanol e $2,5 \mathrm{~mL}$ de cada um dos extratos foram utilizadas como branco. 


\subsubsection{Leitura}

Trinta minutos após a adição da solução de DPPH, as absorbâncias foram medidas em $518 \mathrm{~nm}$, em espectrofotômetro UV-VIS Incibrás MF 200 e convertidas no percentual de atividade antioxidante (AA\%), através da seguinte expressão:

$$
A A \%=100-\frac{\text { At } \times 100}{A C}
$$

$\Rightarrow A t=$ absorbância da solução teste em 518 nm;

$\Rightarrow A c=$ absorbância do controle em $518 \mathrm{~nm}$.

\subsubsection{Cálculo}

A concentração média efetiva (effective median concentration), $\mathrm{EC}_{50}$, è definida como a concentração suficiente para obtenção de $50 \%$ de um efeito máximo estimado em $100 \%$. Na abscissa foi representada a concentração dos extratos e da rutina e, na ordenada, pelo percentual médio de atividade antioxidante, a partir de três ensaios, realizados em periodos distintos. Os ensaios foram realizados em triplicata.

Os valores obtidos de $\mathrm{EC}_{50}$ foram expressos como a média das leituras \pm desvio padrão. Os valores foram obtidos por regressão linear, com um limite de confiança de $95 \%$. 


\subsubsection{Ensaio de ORAC}

O método de ORAC (Oxygen Radical Absorbance Capacity) mede a inibição da oxidação produzida pelo radical peroxila, que reage com um indicador fluorescente para formar um composto não fluorescente, fornecendo uma abordagem na qual o tempo e o grau de inibição são medidos durante a reação (HUANG et al., 2002).

\subsubsection{Reagentes}

Os reagentes utilizados foram fluoresceina sódica, Trolox ${ }^{\circledR}$ (2-carboxi-2,5,7,8tetrametil-6-cromanol) e AAPH [2,2'-azobis(2-amidinopropano) didrocloridrato], Sigma-Aldrich $^{\circledast}$ e fosfato dissódico e fosfato sódico monoidratado, Merck ${ }^{\circledR}$. Para a leitura foi utilizado um leitor de microplaca Synergy ${ }^{\mathrm{TM}} \mathrm{HT}$ Multi-Detection, BioTek Instruments, com filtro de excitação de 485/20 nm e emissão de 528/20 nm.

\subsubsection{Ensaio}

O ensaio foi realizado em uma microplaca de 96 poços. Em cada poço foram colocados $25 \mu \mathrm{L}$ de amostra $(0,039 \mathrm{mg} / \mathrm{mL} ; 0,029 \mathrm{mg} / \mathrm{mL} ; 0,023 \mathrm{mg} / \mathrm{mL} ; 0,019$ $\mathrm{mg} / \mathrm{mL}$ e $0,017 \mathrm{mg} / \mathrm{mL}$ do extrato liofilizado de $P$. alata ou $0,027 \mathrm{mg} / \mathrm{mL} ; 0,022$ $\mathrm{mg} / \mathrm{mL} ; 0,018 \mathrm{mg} / \mathrm{mL} ; 0,014 \mathrm{mg} / \mathrm{mL} ; 0,0125 \mathrm{mg} / \mathrm{mL}$ e $0,011 \mathrm{mg} / \mathrm{mL}$ do extrato liofilizado de $P$. nitida) ou padrão (100 $\mu \mathrm{mol} / \mathrm{L} ; 50 \mu \mathrm{mol} / \mathrm{L} ; 25 \mu \mathrm{mol} / \mathrm{L} ; 12,5 \mu \mathrm{mol} / \mathrm{L}$ e $6,25 \mu \mathrm{mol} / \mathrm{L}$ de Trolox), ambos diluídos em tampão fosfato $(75 \mathrm{mmol} / \mathrm{L} ; \mathrm{pH} 7,0) \mathrm{e}$ $150 \mu \mathrm{L}$ de fluoresceina $(40 \mathrm{nmol} / \mathrm{L})$.

A placa foi incubada por 30 minutos a $37^{\circ} \mathrm{C}$. Após este período adicionou-se $25 \mu \mathrm{L}$ de AAPH (153 mmol/L) diluído em tampão fosfato ( $75 \mathrm{mmol} / \mathrm{L} ; \mathrm{pH} 7,0)$. A placa foi agitada por 10 segundos, no próprio aparelho e a leitura foi efetuada a cada minuto, durante uma hora, com sensibilidade de 60 bottom. $O$ branco consistia de $200 \mu \mathrm{L}$ de tampão fosfato $(75 \mathrm{mmol} / \mathrm{L} ; \mathrm{pH} 7,0)$ e um controle positivo foi preparado, 
no qual o Trolox foi substituído pelo mesmo tampão. Os poços externos àqueles lidos foram preenchidos com $300 \mu \mathrm{L}$ de água para minimizar as perdas de temperatura.

\subsubsection{Cálculo}

O valor final foi calculado através da equação de regressão entre a concentração de Trolox e a área sob a curva de decaimento de fluorescência (AUC). $O$ resultado foi expresso em micromoles equivalentes de Trolox/g de amostra. A área sob a curva foi calculada conforme a equação:

$$
A U C=1+f_{1} / f_{0}+f_{2} / f_{0}+f_{3} / f_{0}+\ldots+f_{n} / f_{0}
$$

$\Rightarrow f_{0}=$ leitura de fluorescência inicial $(t=0)$;

$\Rightarrow f_{n}=$ leitura de fluorescência de cada amostra $(t=n$ minutos $)$.

O valor relativo de ORAC foi calculado conforme a equação:

$$
\frac{\text { (AUC Amostra - AUC Branco) }}{\text { (AUC Trolox - AUC Branco) }} \times \frac{\text { molaridade Trolox }}{\text { conc. da amostra }}
$$




\subsection{Atividade antiúlcera aguda}

\subsubsection{Animais}

Ratos Wistar Hannover fêmeas, pesando 150 a $180 \mathrm{~g}$, foram mantidos em jejum por 12 horas antes dos ensaios, com livre acesso à água e temperatura ambiente de 22 a $25^{\circ} \mathrm{C}$. Os animais, provenientes do Biotério da Faculdade de Ciências Farmacêuticas da Universidade de São Paulo, foram divididos de forma randômica em cinco grupos de oito animais durante os ensaios. O protocolo para a utilização de animais neste estudo foi aprovado pela Comissão de Ética em Experimentação Animal da Faculdade de Ciências Farmacêuticas da Universidade de São Paulo e documentado no protocolo número 132/2006.

\subsubsection{Ensaio}

\subsubsection{Tratamento com extrato hidroetanólico liofilizado}

$\mathrm{Na}$ avaliação da atividade antiúlcera foram utilizados os extratos liofilizados de $P$. alata e $P$. nitida. Lansoprazol Hexal ${ }^{\circledR}$ foi empregado como controle positivo e água como controle negativo. Cada um dos extratos, dissolvido em água, foi administrado por gavagem, nas doses de 100, 200 e $400 \mathrm{mg} / \mathrm{kg}$.

Lansoprazol, em água, foi administrado na dose de $30 \mathrm{mg} / \mathrm{kg}$. Os extratos, lansoprazol e a água foram administrados em um volume de $10 \mathrm{~mL} / \mathrm{kg}$.

O preparo dos extratos, dos controles e do agente indutor (item 4.7.2.2, p. 54), foi realizado pouco antes da administração aos animais. 


\subsubsection{Procedimento para produção de lesão gástrica}

Trinta minutos após o tratamento com cada um dos extratos e a administração dos controles, foi administrado por via oral $150 \mathrm{mmol} / \mathrm{L}$ de ácido cloridrico em etanol $60 \%(\mathrm{v} / \mathrm{v})$ em um volume de $10 \mathrm{~mL} / \mathrm{kg}$ (MIZUI; DOTEUCHI, 1983; YAMADA et al., 1991) para indução das úlceras. A acidificação do etanol acelera o desenvolvimento e agrava a severidade das lesões gástricas. Os animais foram mortos em uma câmara de dióxido de carbono uma hora após a administração; os estômagos foram removidos e abertos pela curvatura maior.

Alternativamente, o agente indutor foi administrado por via oral na concentração de $300 \mathrm{mmol} / \mathrm{L}$ de ácido clorídrico em etanol $60 \%$ (v/v) em um volume de $10 \mathrm{~mL} / \mathrm{kg}$, para comparação com a concentração de $150 \mathrm{mmol} / \mathrm{L}$. O procedimento do ensaio foi o mesmo.

\subsubsection{Cálculo}

A extensão de cada lesão foi medida através do programa Image-Pro Plus e as lesões foram expressas através da área total de lesão $\left(A T L, e m m^{2}\right)$ e da área relativa de lesão (ARL, em porcentagem). $A$ área relativa de lesão foi calculada através da seguinte expressão:

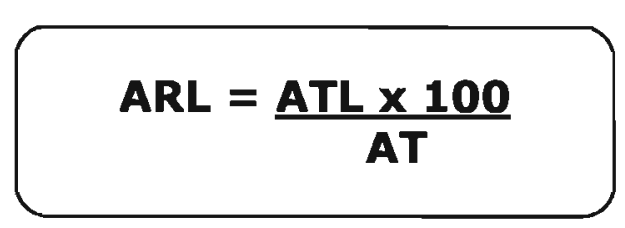

$\Rightarrow A T L=$ área total de lesão, $\mathrm{em} \mathrm{mm}^{2}$;

$\Rightarrow \mathrm{AT}=$ área total do estômago, $\mathrm{em} \mathrm{mm}^{2}$. 
Para a análise estatística, as áreas relativas de lesão foram transformadas através da função arco seno.

\subsubsection{Análise estatística}

Os dados foram analisados através de ANOVA e do teste de Tukey, com auxílio do programa Instat. Foram avaliadas as diferenças entre o controle negativo para os extratos e o padrão, sendo expressos como área total de lesão (ATL), em $\mathrm{mm}^{2}$ e área relativa de lesão ( $A R L$ ), em porcentagem, na forma: média \pm EPM (erro padrão da média). Os resultados foram considerados significativos para $p<0,05$. 


\section{Resultados}

\subsection{Estudo farmacobotânico}

\subsubsection{Passiflora alata Curtis}

\subsubsection{Descrição macroscópica}

As folhas de $P$. alata são inteiras, oval a oval-elípticas, glabras, de base arredondada a ligeiramente cordada, ápice agudo a acuminado, peninérveas com seis a oito nervuras laterais de cada lado da nervura mediana, de consistência membranácea e de margens onduladas (Figura 11A). Medem de 11 a $16 \mathrm{~cm}$ de comprimento por 6 a $12 \mathrm{~cm}$ de largura. Os pecíolos canaletados, portam geralmente dois pares de glândulas sésseis. As estípulas são lineares e as gavinhas, axilares. $O$ caule quadrangular é provido de alas e fístula (Figura 13A). As folhas desidratadas são verde-acastanhadas, inodoras e de sabor amargo.
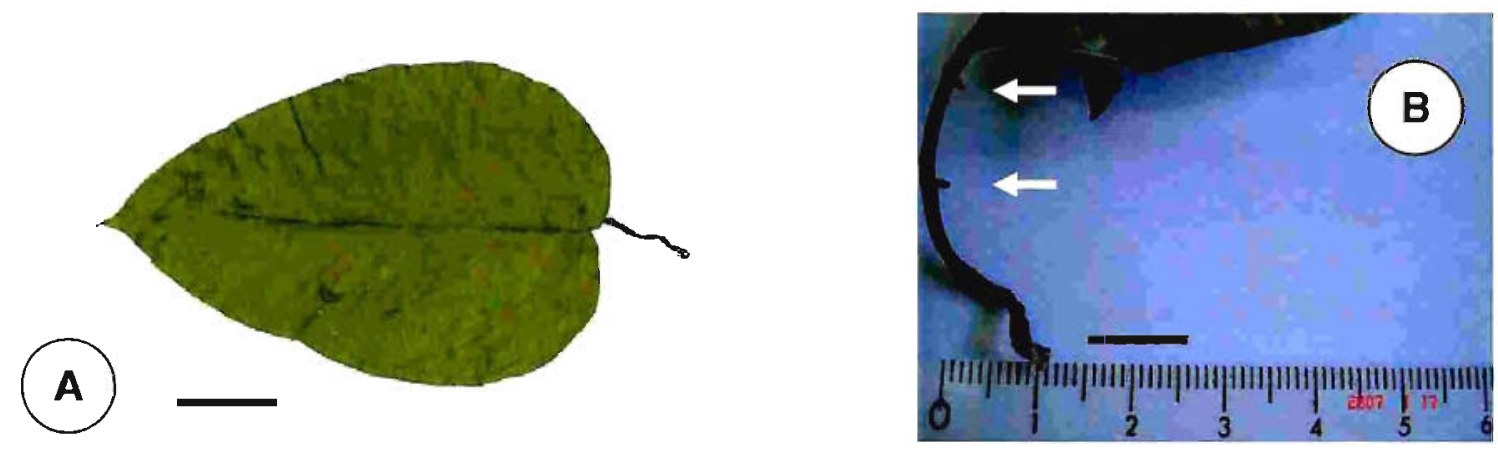

Figura 11. Passiflora alata Curtis. (A) folha desidratada; (B) detalhe do pecíolo com as glândulas (setas). Escalas: (A) $3 \mathrm{~cm}$; (B) $1 \mathrm{~cm}$. 


\subsubsection{Descrição microscópica}

As células epidérmicas, em vista frontal, exibem contorno poligonal, paredes ligeiramente sinuosas, providas de espessamentos semelhantes a contas de rosário. A cutícula é lisa (Figura 12A, B). A folha hipoestomática apresenta estômatos ladeados por duas a quatro células (Figura 12B). A secção transversal da lâmina foliar permite observar na face adaxial, células epidérmicas ligeiramente alongadas no sentido periclinal. Na face abaxial, essas células evidenciam maior irregularidade na forma e no tamariho. O mesofilo dorsiventral mostra uma camada de células paliçádicas que alcança de um quinto a um quarto da espessura do mesmo e, de até 10 camadas de células braciformes (Figura 12C). A nervura mediana é pronunciadamente biconvexa (Figura 12D, E, F). A epiderme é formada por células aproximadamente quadrangulares, com as paredes periclinais externas ligeiramente convexas. Na face abaxial, essas células apresentam-se comparativamente menores. O colênquima angular ocorre sob as duas faces (Figura 12E, F). O sistema vascular, de forma arqueada, mostra um feixe maior aposto a outros quatro ou cinco feixes menores. Os feixes vasculares colaterais exibem fibras perivasculares lignificadas (Figura 12D). Drusas de oxalato de cálcio são observadas principalmente no parênquima fundamental e no floema (Figura 12D, E, F). No pecíolo de contorno côncavo-convexo, provido de alas, à medida que o seu diâmetro diminui, as alas sofrem redução. Sob a epiderme observam-se três a nove camadas de colênquima angular. $O$ sistema vascular dispõe-se em círculo; sob cada ala, encontra-se um feixe vascular de pequeno porte.

O caule, de contorno marcadamente quadrangular (Figura 13A), exibe estrutura eustélica (Figura 13B, C). As células epidérmicas de tamanho e contorno variáveis são revestidas por cutícula lisa. O colênquima, parênquima cortical e medular assemelham-se aos tecidos encontrados no peciolo. $\mathrm{Na}$ figura $13 \mathrm{C}$ destaca-se a presença de camada amilífera. Apostos ao floema encontram-se grupos de fibras (Figura 13D). Drusas ocorrem no parênquima cortical, medular e do sistema vascular. Cristais prismáticos encontram-se principalmente junto aos elementos vasculares (Figura 13E, F). O parênquima medular constituído de células arredondandas apresenta lignificação nas estrutura’s secundárias bem desenvolvidas. 

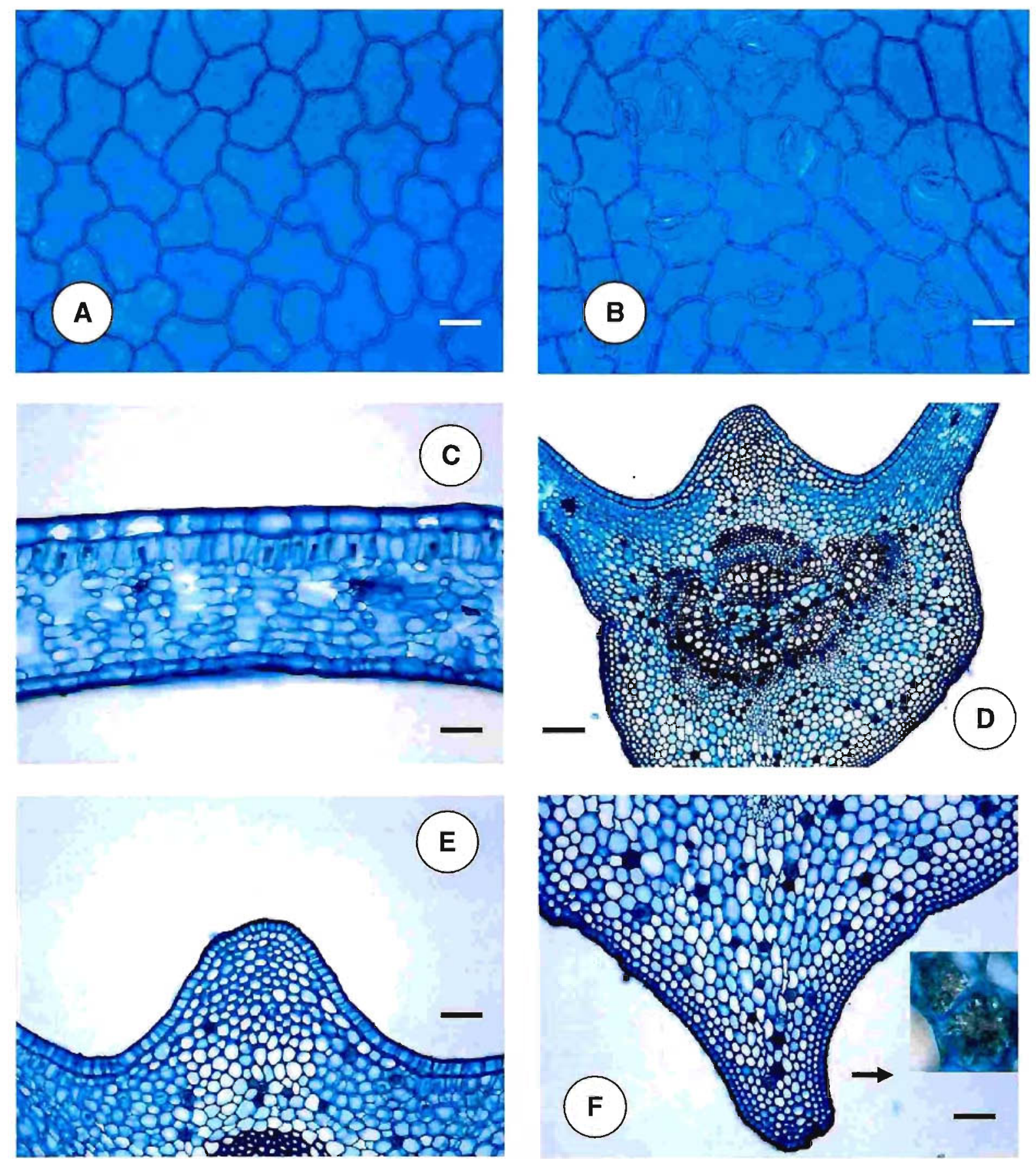

Figura 12. Folha de Passiflora alata Curtis. (A) e (B) vistas frontais da epiderme; (A) face adaxial; $(B)$ face abaxial; (C) - (F) cortes transversais; (C) mesofilo dorsiventral; (D) - (F) nervura mediana; (D) aspecto geral; (E) detalhe junto à face adaxial; (F) detalhe junto à face abaxial. Escalas: (A) e (B) $5 \mu \mathrm{m}$; (C) $10 \mu \mathrm{m}$; (D) $40 \mu \mathrm{m}$; (E) e (F) $20 \mu \mathrm{m}$, drusas no detalhe $5 \mu \mathrm{m}$. 

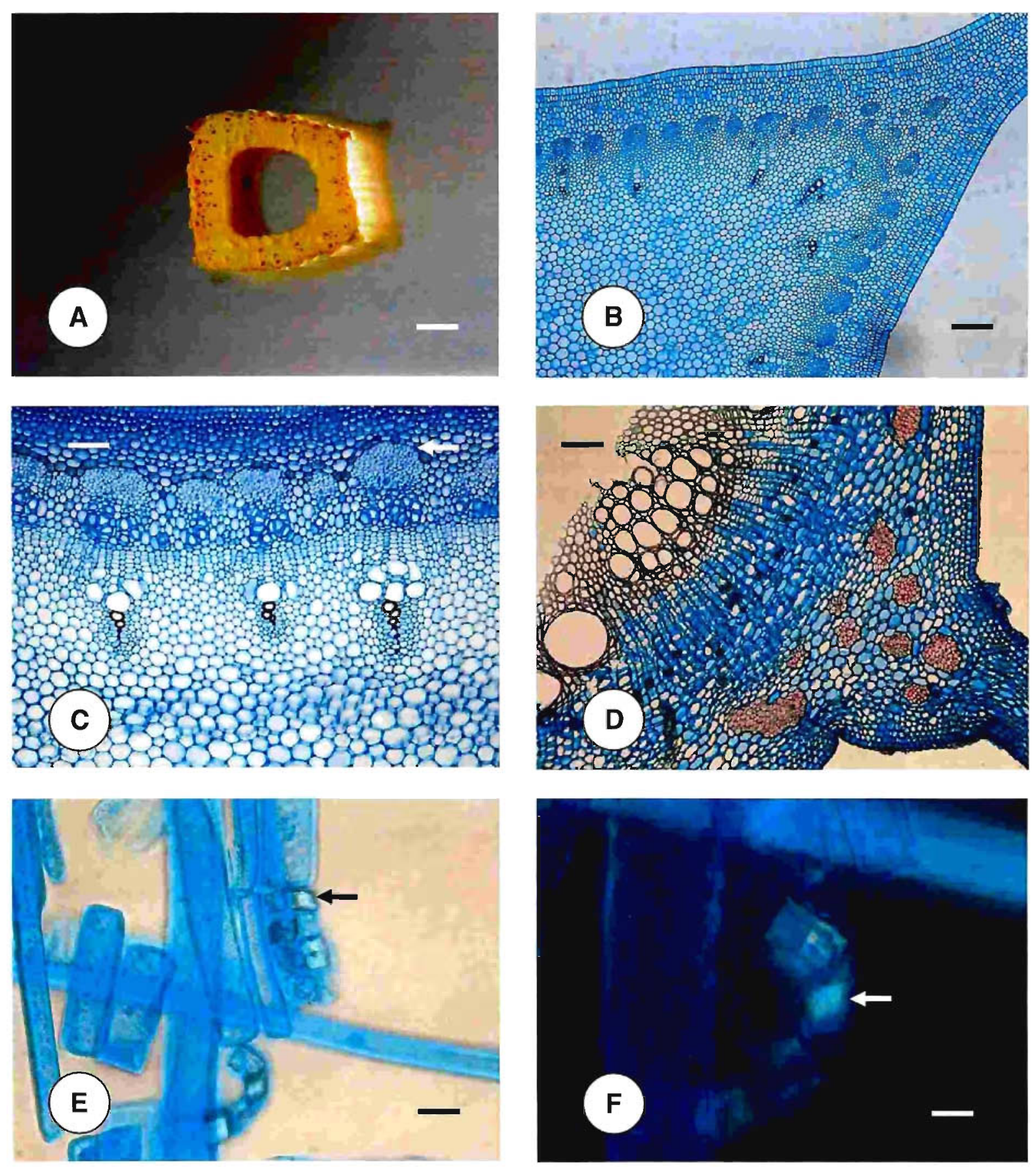

Figura 13. Caule de Passiflora alata Curtis. (A) secção transversal do caule; (B) detalhe da expansão do caule; (C) região entre as alas, evidenciando camada amilífera (seta); (D) detalhe do caule em estrutura secundária; $(E)$ e (F) caule dissociado, com destaque a cristais prismáticos (setas); (F) material observado sob luz polarizada. Escalas: (A) $1 \mathrm{~mm}$ (B) - (D) $20 \mu \mathrm{m}$; (E) $5 \mu \mathrm{m}$; (F) $2 \mu \mathrm{m}$. 


\subsubsection{Passiflora nitida Kunth}

\subsubsection{Descrição macroscópica}

As folhas de $P$. nitida são inteiras, oval-oblongas, oval-elípticas, agudas a acuminadas, arredondadas, subcoriáceas, glabras, de 8 a $18 \mathrm{~cm}$ de comprimento, de 5 a $10 \mathrm{~cm}$ de largura e de coloração verde brilhante nas duas faces. Exibem estípulas linear-subuladas e apresentam pecíolos recurvados, de 4 a $6 \mathrm{~cm}$ de comprimento, providos de um par de glândulas (Figura 14). O caule arredondado, provido de fístula, mostra estrias longitudinais (Figura 16).
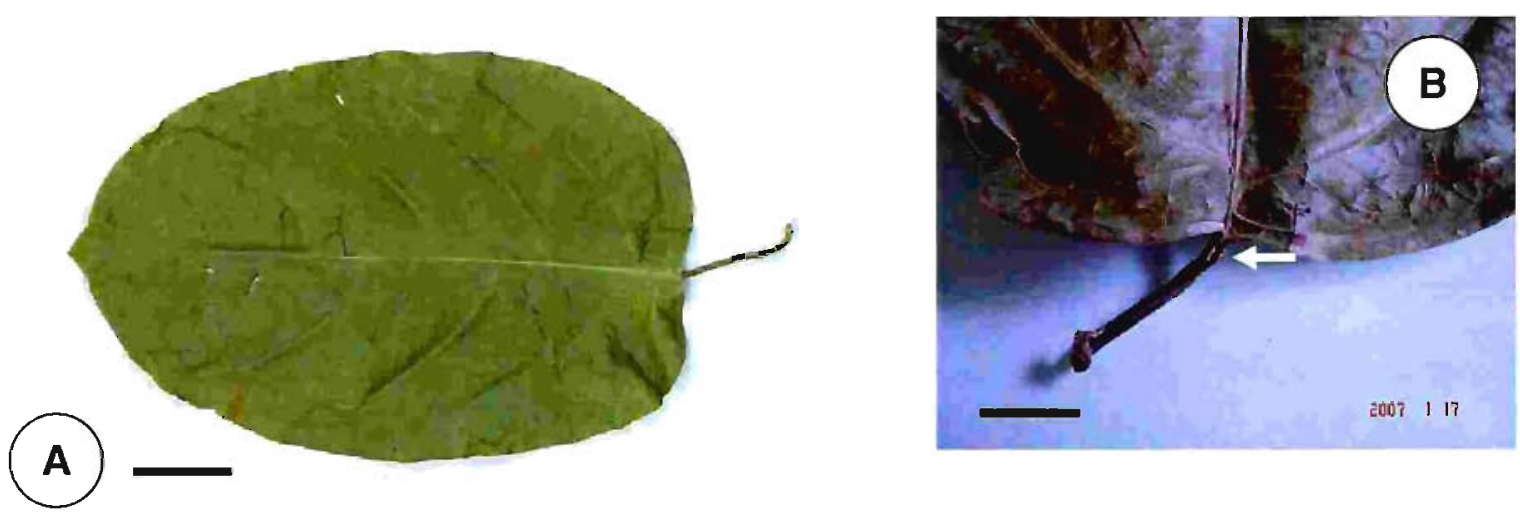

Figura 14. Passiflora nitida Kunth. (A) folha desidratada; (B) detalhe do peciolo com as glândulas (seta). Escalas: (A) $3 \mathrm{~cm}$; (B) $1 \mathrm{~cm}$.

\subsubsection{Descrição microscópica}

A folha hipoestomática apresenta estômatos no mesmo nível das demais células epidérmicas (Figura 15D). Em vista frontal, as células epidérmicas exibem formato poligonal (Figura 15A), ligeiramente sinuosas na face abaxial, onde se observam estômatos ladeados por 3 a 4 células, predominando os estômatos anisocíticos. As paredes das células epidérmicas são providas de espessamentos semelhantes a contas de rosário (Figura 15B, C). 
Em seç̧ão transversal, as células epidérmicas da face adaxial mostram-se alongadas em sentido periclinal; as da face abaxial são aproximadamente quadrangulares e proporcionalmente maiores. O mesofilo dorsiventral é constituído por uma camada em paliçada, que alcança de um quarto a um terço da espessura do mesmo e, de até 10 camadas de células braciformes (Figura 15D). A nervura biconvexa é revestida por células epidérmicas de formato semelhante ao descrito para a região laminar, mas comparativamente menores (Figura 15E, F). O colênquima angular ocorre sob as duas faces. O sistema vascular dispõe-se em arco aberto, aposto ao qual se observa um feixe maior voltado para a face adaxial. $\mathrm{O}$ peciolo apresenta contorno predominantemente arredondado, apresentando expansões na região das glândulas. Sob a epiderme observam-se camadas de colênquima angular intercalados por estreitas faixas de células parenquimáticas. $\mathrm{O}$ sistema vascular dispõe-se de forma circular e sob cada ala, encontra-se um feixe vascular de pequeno porte.

A secção transversal do caule, em estrutura primária, observada logo abaixo da região meristemática, apresenta contorno irregular provido, por vezes, de quatro reentrâncias e estrutura eustélica (Figura 16B, C). As células epidérmicas aproximadamente quadrangulares são revestidas por cutícula lisa. Sob a epiderme observam-se camadas de células arredondadas de paredes celulósicas finas, delimitando espaços intercelulares reduzidos, com conteúdo dourado (Figura 16C, D). Em presença de solução de cloreto férrico, estas células adquirem coloração verde-azulada. Em crescimento secundário, encontram-se grupos de fibras apostas ao floema e parênquima medular com espessamento lignificado (Figura 16E). Raras drusas de oxalato de cálcio são observadas nos parênquimas. Cristais prismáticos foram observados principalmente nas regiões perivasculares (Figura 16F). 

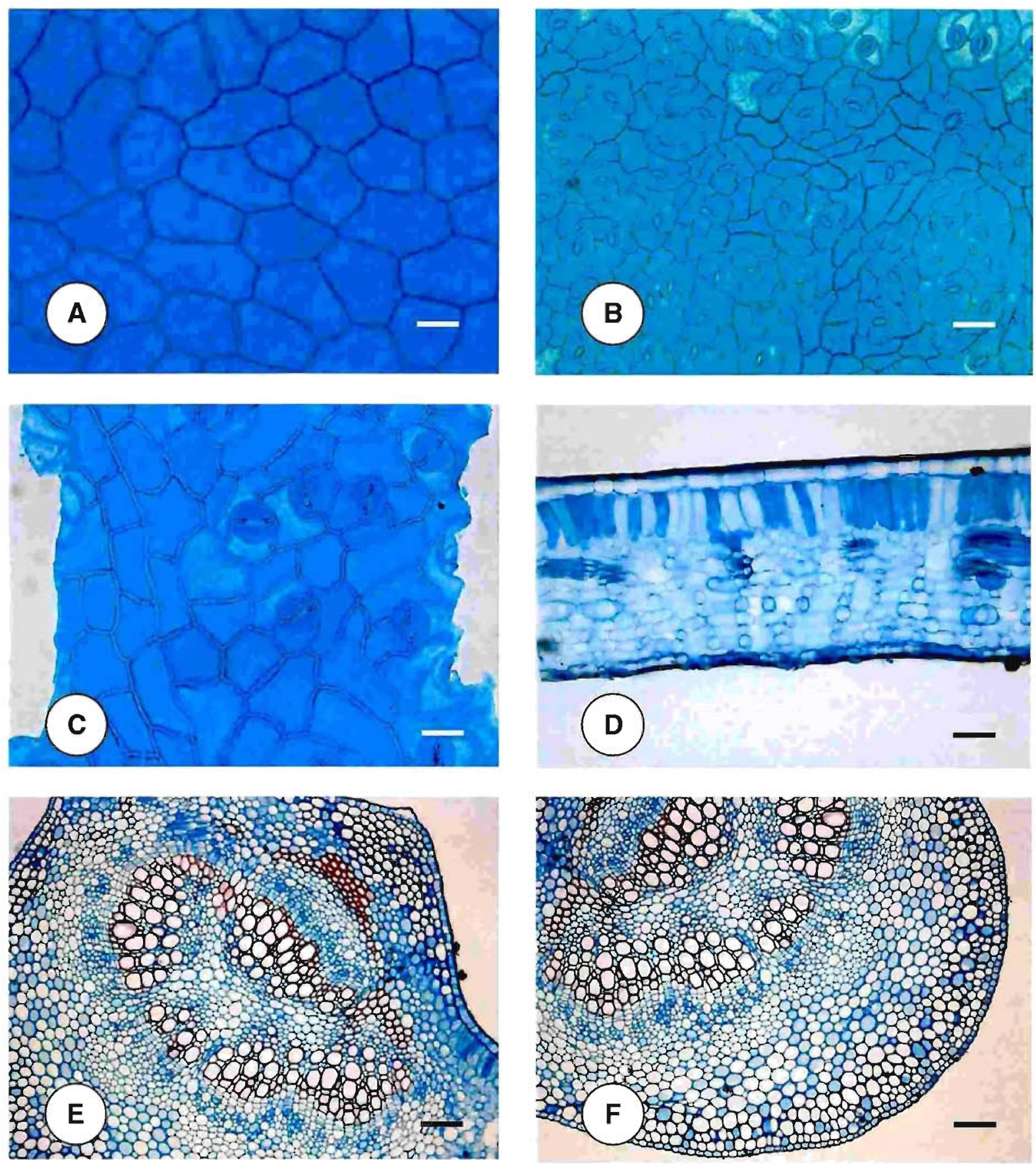

Figura 15. Folha de Passiflora nitida Kunth. (A) - (C) vistas frontais; (A) face adaxial; (B) e (C) face abaxial; (D) - (F) secções transversais; (D) mesofilo dorsiventral; (E) e (F) nervura mediana; $(E)$ aspecto geral da nervura mediana; $(F)$ detalhe do feixe vascular e região junto à face adaxial. Escalas: (A) $5 \mu \mathrm{m}$; (B) $10 \mu \mathrm{m}$; (C) $5 \mu \mathrm{m}$; (D) 10 $\mu \mathrm{m} ;(E)$ e (F) $20 \mu \mathrm{m}$. 

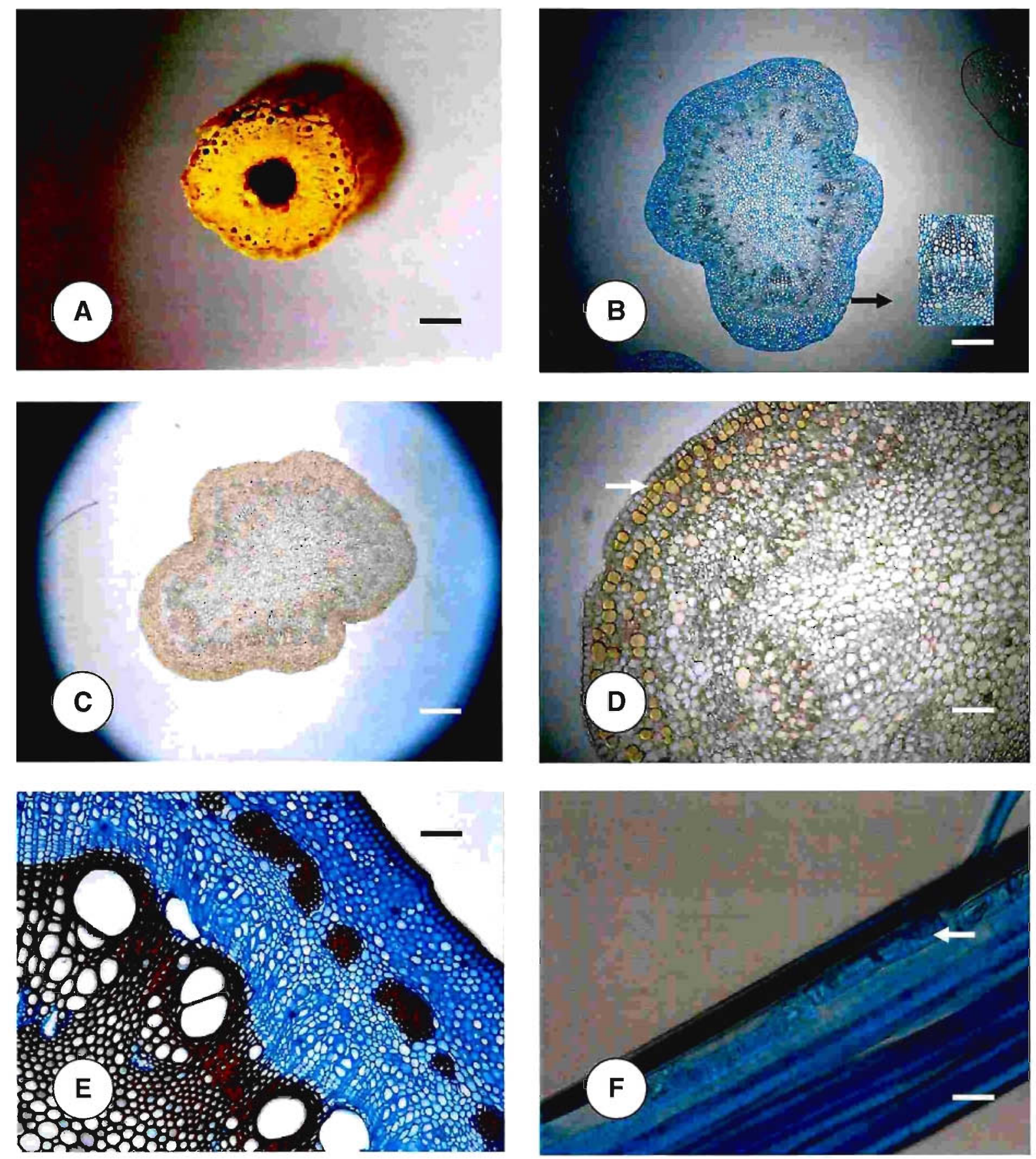

Figura 16. Caule de Passiflora nitida Kunth. (A) - (E) secções transversais do caule; (B) feixe vascular no detalhe: $40 \mu \mathrm{m}$; (C) e (D) coloração natural; (D) destaque ao conteúdo celular alaranjado (seta); (E) caule em estrutura secundária; (F) caule dissociado com destaque aos cristais prismáticos (seta). Escalas: (A) 0,8 mm (B) e (C) $80 \mu \mathrm{m}$; (D) e (E) $20 \mu \mathrm{m}$; (F) $5 \mu \mathrm{m}$. 


\subsection{Triagem fitoquímica}

\subsubsection{Flavonóides}

A figura 17 apresenta o cromatograma em camada delgada comparativo do perfil flavonoídico da droga vegetal e do extrato liofilizado de $P$. alata e $P$. nitida.
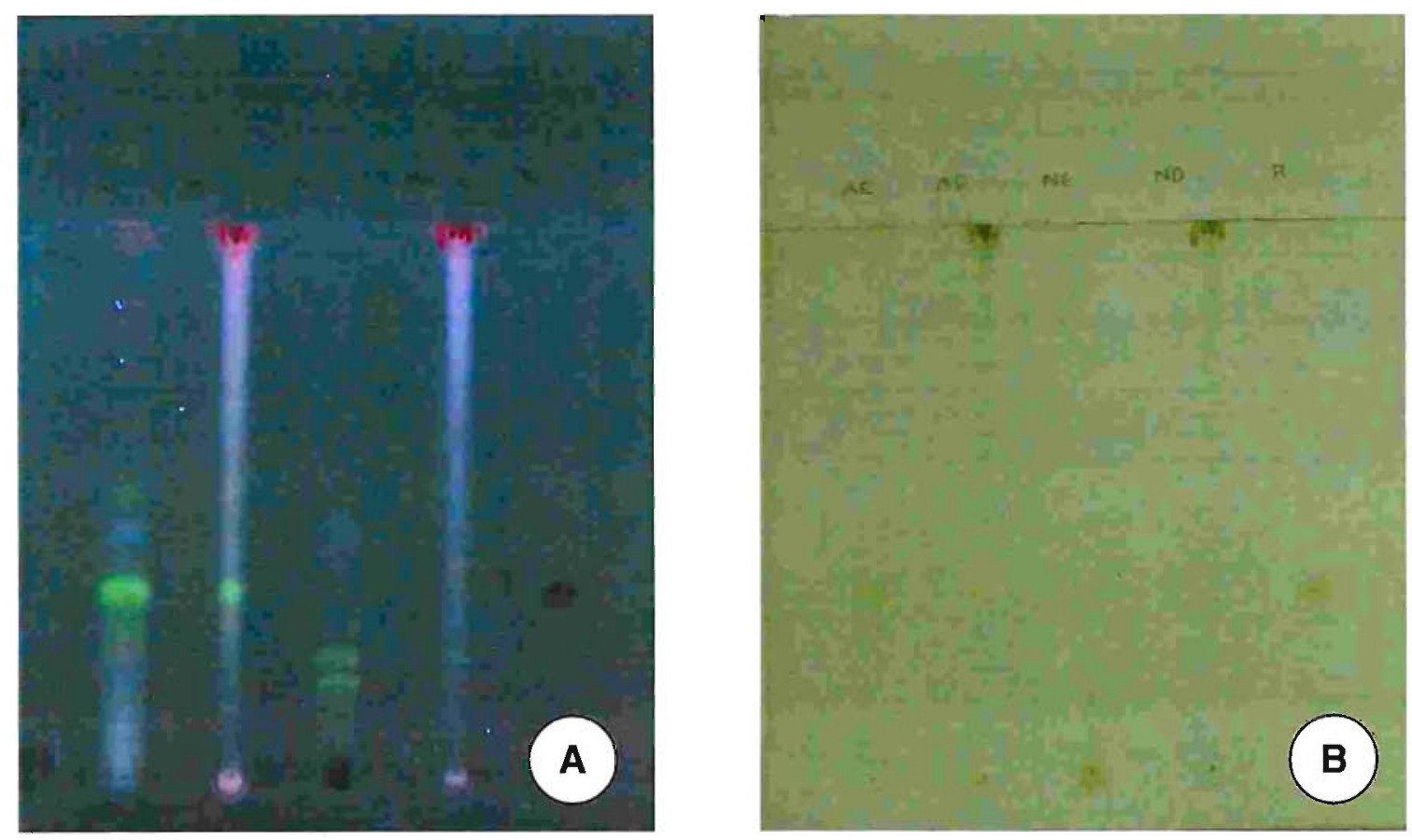

Figura 17. Cromatograma em camada delgada comparativo de Passiflora alata Curtis e $P$. nitida Kunth. Fase móvel: acetato de etila - ácido fórmico - ácido acético glacial - água (100:11:11:26). Fase fixa: sílica $60 \mathrm{GF}_{254}$. Revelação com NP (WAGNER, BLADT, 1996) e visualização sob (A) luz UV a $365 \mathrm{~nm}$ e (B) luz visível. Da esquerda para a direita: $P$. alata - extrato liofilizado, $P$. alata - droga vegetal, $P$. nitida - extrato liofilizado, $P$. nitida - droga vegetal e rutina (substância de referência). 


\subsubsection{Saponinas}

$\mathrm{Na}$ triagem fitoquímica apenas o extrato de $P$. alata produziu espuma persistente. A droga vegetal e o extrato liofilizado de $P$. alata apresentaram atividade hemolitica, este último em maior proporção (Tabela 5). Alcalóides não foram evidenciados na droga vegetal ou extratos de ambas as espécies.

Tabela 5. Avaliação da presença de saponinas nas drogas vegetais e nos extratos liofilizados de Passiflora alata Curtis e $P$. nitida Kunth.

\begin{tabular}{ccccc}
\hline \multirow{2}{*}{ Índices } & \multicolumn{2}{c}{ Passiflora alata } & \multicolumn{2}{c}{ Passiflora nitida } \\
\cline { 2 - 5 } & Droga vegetal & Extrato liofilizado & Droga vegetal & Extrato liofilizado \\
\hline Espuma & 4 & - & - & - \\
\hline Hemólise & 8 & 32 & - & - \\
\hline
\end{tabular}

$(-)=$ resultado negativo

\subsection{Flavonóides totais}

O resultado da avaliação do teor de flavonóides totais nas drogas vegetais e nos extratos liofilizados de $P$. alata e de $P$. nitida são apresentados na tabela 6 .

Tabela 6. Teor de flavonóides nas drogas vegetais e nos extratos liofilizados de Passiflora alata Curtis e de $P$. nitida Kunth.

\begin{tabular}{ccc}
\hline Material analisado & Passiflora alata & Passiflora nitida \\
\hline Droga vegetal & $0,42 \% \pm 0,01$ & $0,10 \% \pm 0,01$ \\
\hline Extrato liofilizado & $0,67 \% \pm 0,01$ & $0,23 \% \pm 0,01$ \\
\hline
\end{tabular}




\subsection{Atividade antioxidante}

\subsubsection{Ensaio do DPPH}

P. alata apresentou $\mathrm{EC}_{50}$ de $1061,2 \pm 8,5 \mu \mathrm{g} / \mathrm{mL} ; P$. nitida apresentou $\mathrm{EC}_{50}$ de $128,0 \pm 0,9 \mu \mathrm{g} / \mathrm{mL}$ e o controle positivo, rutina, apresentou $\mathrm{EC}_{50}$ de $18,3 \pm 0,9 \mu \mathrm{g} / \mathrm{mL}$. Os valores de $\mathrm{EC}_{50}$ foram obtidos por regressão linear e mostraram um coeficiente de linearidade $\left(r^{2}\right)$ maior que 0,97 . Tratamento estatístico por ANOVA dos resultados obtidos para os três testes separados mostrou que os ensaios para cada extrato são estatisticamente equivalentes $(p=0,05)$.

\subsubsection{Ensaio de ORAC}

Como o valor de ORAC é calculado em equivalentes de Trolox, a obtenção da equação da reta do gráfico de concentração de Trolox em função da diferença de área sob a curva (AUC Trolox - AUC controle), é fundamental para a avaliação das amostras.

Os dados da equação da reta padrão de Trolox são empregados para o cálculo de equivalentes de Trolox das amostras, por meio da interpolação das curvas.

As curvas de cinética de diferentes concentrações de Trolox demonstram diferentes graus de proteção da fluoresceína contra a oxidação, que leva à perda de fluorescência. A concentração mais alta de Trolox (100 $\mu \mathrm{mol} / \mathrm{L})$ apresentou proteção total da fluoresceína por aproximadamente 45 minutos, antes que a intensidade de fluorescência começasse a decair, enquanto que a concentração mais baixa $(6,25$ $\mu \mathrm{mol} / \mathrm{L}$ ) protegeu a fluoresceína por apenas alguns minutos.

Os extratos de $P$. alata e $P$. nitida foram capazes de promover a proteção da fluoresceína, como foi possivel observar nas curvas de cinética de decaimento para ambos os extratos. Apesar disto o valor de ORAC obtido para o extrato de $P$. nitida foi mais alto, indicando uma maior atividade antioxidante deste extrato. 
Ambos os extratos apresentaram atividade antioxidante dependente da concentração. A atividade antioxidante do extrato liofilizado de $P$. alata foi de $1076 \pm$ $85 \mu \mathrm{mol}$ de Trolox/g de extrato e a atividade antioxidante do extrato liofilizado de $P$. nitida foi de $1985 \pm 104 \mu \mathrm{mol}$ de Trolox/g de extrato. 


\subsection{Atividade antiúlcera aguda}

\subsubsection{Passiflora alata Curtis}

A figura 18 apresenta os estômagos dos ratos, abertos pela curvatura maior, submetidos ao ensaio da atividade antiúlcera aguda, empregando-se o extrato liofilizado de $P$. alata.
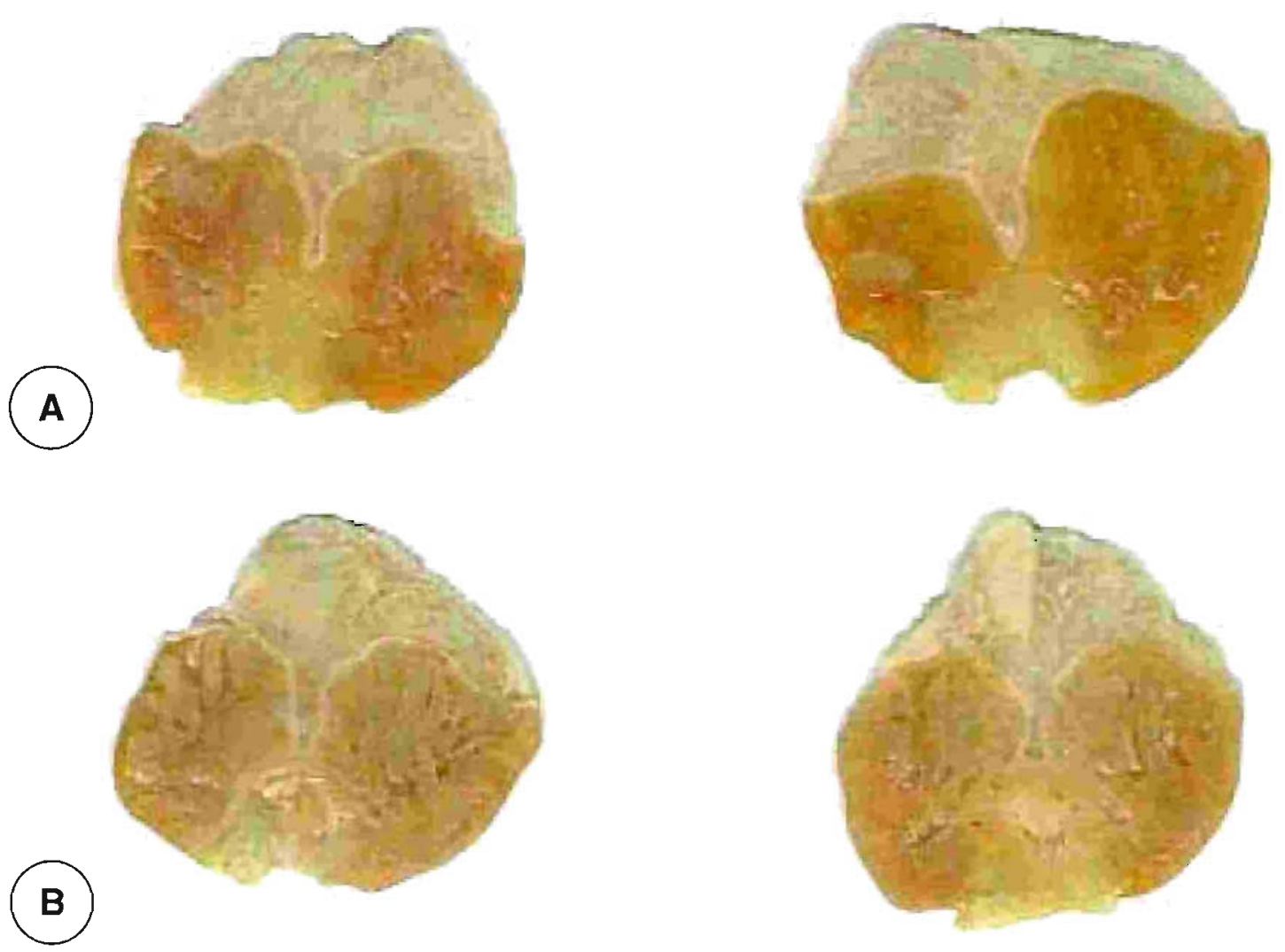

Figura 18. Atividade antiúlcera do extrato liofilizado de Passiflora alata Curtis. Na figura, em linha horizontal, estão representados 2 estômagos abertos pela curvatura maior, de cada grupo de ratos submetido ao ensaio. Administração intragástrica e indução de úlcera por etanol e ácido clorídrico $(150 \mathrm{mmol} / \mathrm{L}$ de ácido em $60 \% \mathrm{v} / \mathrm{v}$ de etanol). $n=8$. (A) animais tratados com $100 \mathrm{mg} / \mathrm{kg}$ de extrato; (B) animais tratados com $200 \mathrm{mg} / \mathrm{kg}$ de extrato. 

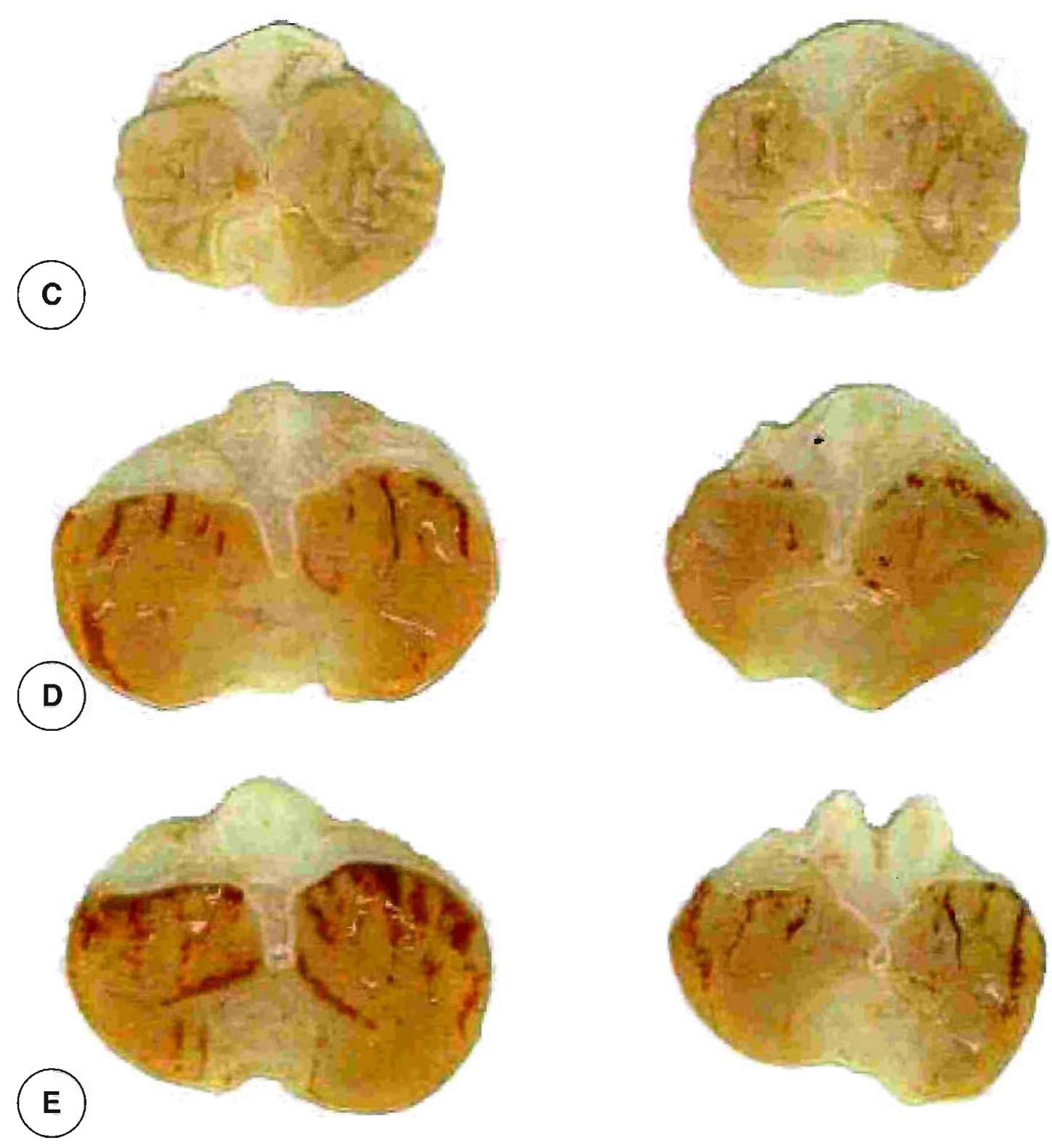

Figura 18. Atividade antiúlcera do extrato liofilizado de Passiflora alata Curtis. Na figura, em linha horizontal, estão representados 2 estômagos abertos pela curvatura maior, de cada grupo de ratos submetido ao ensaio. Administração intragástrica e indução de úlcera por etanol e ácido clorídrico ( $150 \mathrm{mmol} / \mathrm{L}$ de ácido em $60 \% \mathrm{v} / \mathrm{v}$ de etanol). $n=8$. (C) animais tratados com $400 \mathrm{mg} / \mathrm{kg}$ de extrato; (D) animais tratados com $30 \mathrm{mg} / \mathrm{kg}$ de lansoprazol; (E) animais tratados com água.

O resultado da avaliação da atividade antiúlcera gástrica do extrato liofilizado de $P$. alata, encontra-se na tabela 7 e nas figuras 19 e 20. 
Tabela 7. Atividade antiúlcera do extrato liofilizado de Passiflora alata Curtis. Indução de úlcera por etanol e ácido clorídrico ( $150 \mathrm{mmol} / \mathrm{L}$ de ácido em $60 \% \mathrm{v} / \mathrm{v}$ de etanol).

\begin{tabular}{ccccc}
\hline Área de lesão & $\boldsymbol{P}$. alata 100 & $\boldsymbol{P}$. alata 200 & P. alata 400 & Lansoprazol \\
\hline ATL & $100 \%^{* *}$ & $100 \%^{* *}$ & $100 \%^{* *}$ & $75 \%^{*}$ \\
\hline ARL & $100 \%^{* *}$ & $100 \%^{* *}$ & $100 \%^{* *}$ & $76,92 \%^{*}$ \\
\hline
\end{tabular}

O extrato foi administrado por gavagem nas doses de 100, 200 e $400 \mathrm{mg} / \mathrm{kg}$; lansoprazol na dose de $30 \mathrm{mg} / \mathrm{kg} . \mathrm{n}=8$. ${ }^{*} p<0,05 ;{ }^{*} p<0,01 . A T L=$ área total de lesão, em mm²; $A R L$ = área relativa de lesão, em porcentagem.

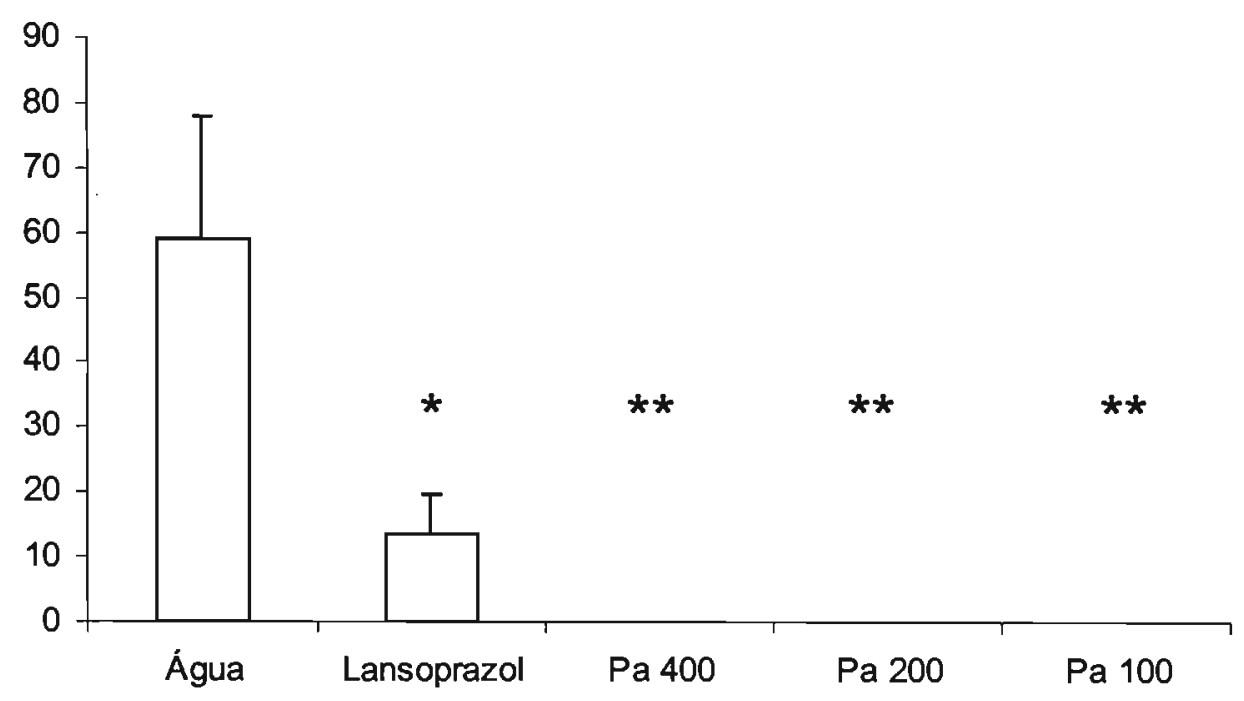

Figura 19. Atividade antiúlcera do extrato liofilizado de Passiflora alata Curtis. Área total de lesão gástrica (ATL, em $\mathrm{mm}^{2}$ ) induzida por etanol e ácido clorídrico (150 $\mathrm{mmol} / \mathrm{L}$ de ácido em $60 \% \mathrm{v} / \mathrm{v}$ de etanol), em ratos após administração intragástrica. Cada coluna representa a média \pm EPM. $n=8$. ${ }^{*} p<0,05 ;{ }^{* \star} p<0,01$. Pa $=$ extrato de Passiflora alata. Controle positivo $=$ lansoprazol. Controle negativo $=$ água. 


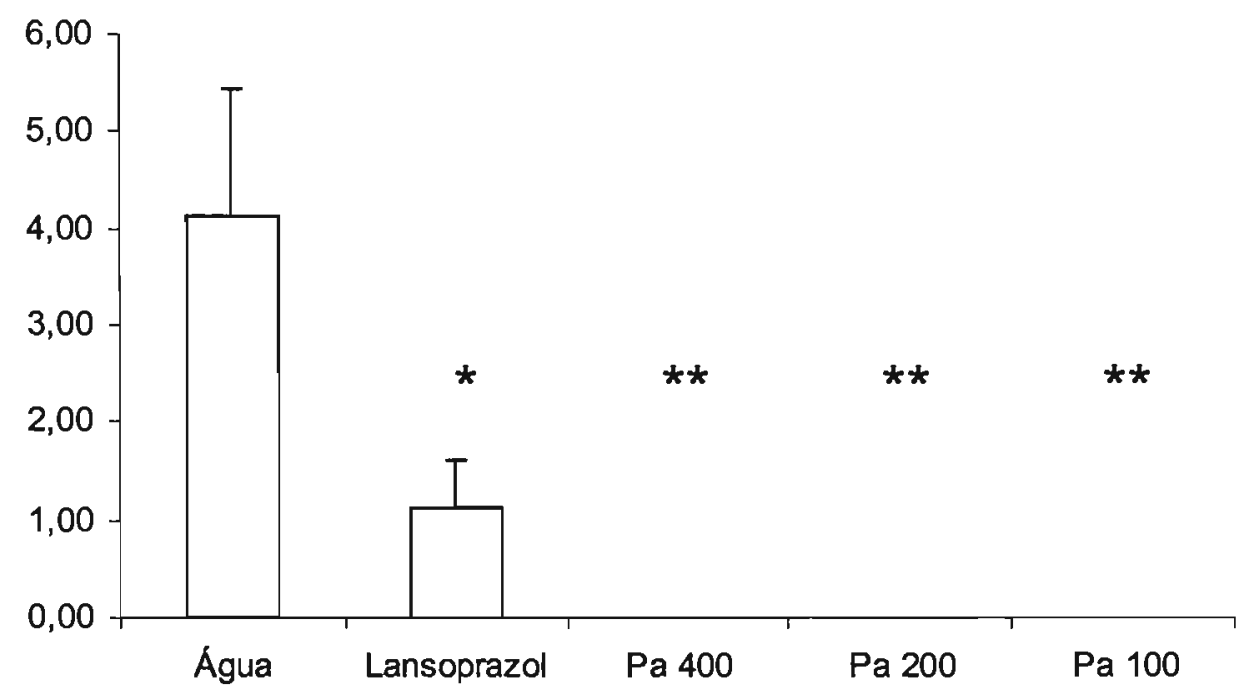

Figura 20. Atividade antiúlcera do extrato liofilizado de Passiflora alata Curtis. Área relativa de lesão gástrica ( $A R L$, em \%) induzida por etanol e ácido clorídrico (150 $\mathrm{mmol} / \mathrm{L}$ de ácido em $60 \% \mathrm{v} / \mathrm{v}$ de etanol), em ratos após administração intragástrica. Cada coluna representa a média \pm EPM. $n=8$. ${ }^{\star} p<0,05 ;{ }^{* \star} p<0,01$. $\mathrm{Pa}=$ extrato de Passiflora alata. Controle positivo $=$ lansoprazol. Controle negativo $=$ água.

No cálculo da área total de lesão (ATL), o extrato liofilizado de $P$. alata exibiu efeito de proteção contra as lesões gástricas de 100\% nas doses de 100, 200 e 400 $\mathrm{mg} / \mathrm{kg}$ e o controle positivo, lansoprazol, de $75 \%$.

No cálculo da área relativa de lesão (ARL), $P$. alata exibiu efeito de proteção contra as lesões gástricas de $100 \%$ nas doses de 100, 200 e $400 \mathrm{mg} / \mathrm{kg}$ e o controle positivo, lansoprazol, de $76,92 \%$. 


\subsubsection{Passiflora nitida Kunth}

A figura 21 apresenta os estômagos dos ratos, abertos pela curvatura maior, submetidos ao ensaio da atividade antiúlcera aguda, empregando-se o extrato liofilizado de $P$. nitida.
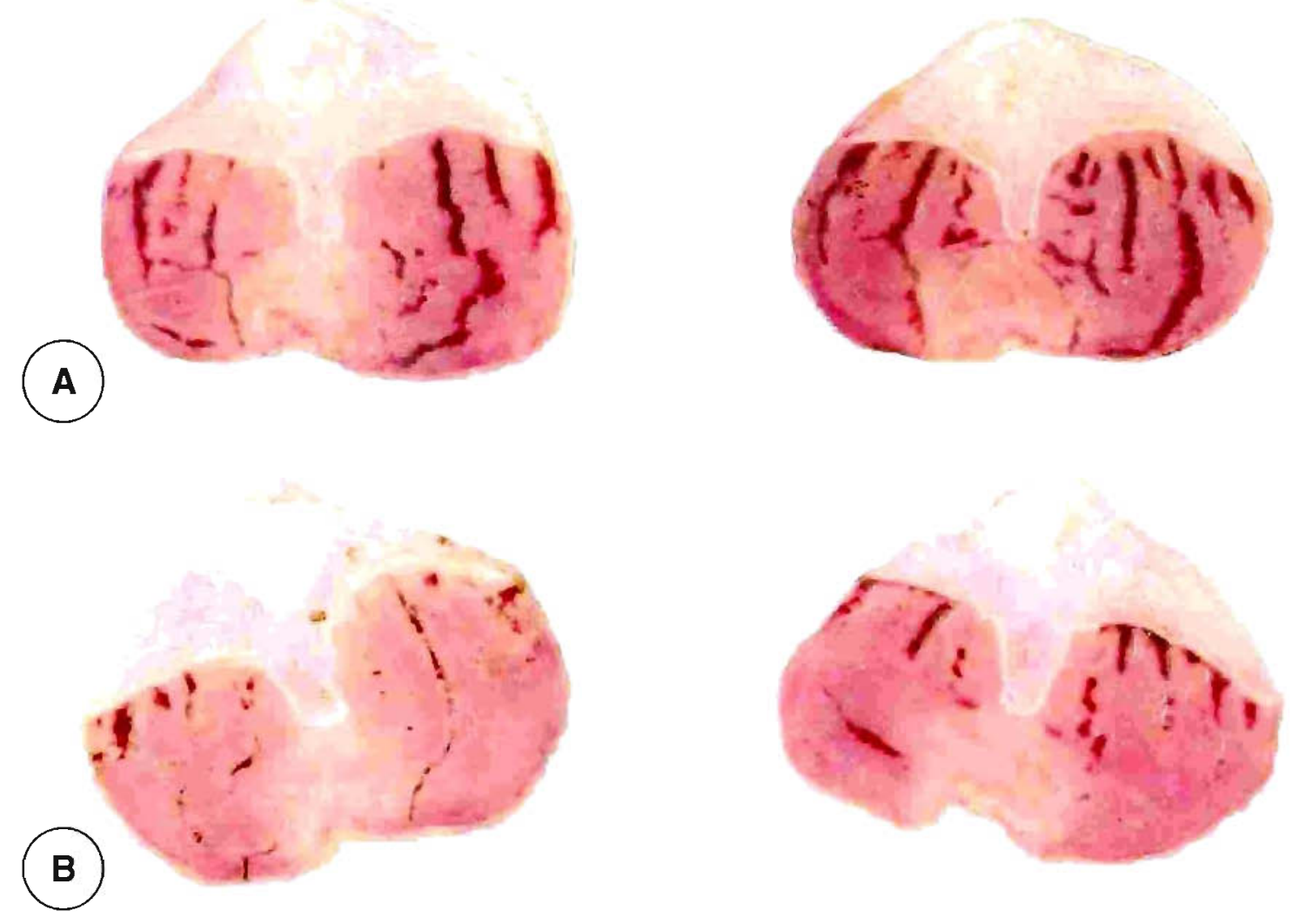

Figura 21. Atividade antiúlcera do extrato liofilizado de Passiflora nitida Kunth. Na figura, em lirıha horizontal, estão representados 2 estômagos abertos pela curvatura maior, de cada grupo de ratos submetido ao ensaio. Administração intragástrica e indução de úlcera por etanol e ácido clorídrico $(150 \mathrm{mmol} / \mathrm{L}$ de ácido em $60 \% \mathrm{~V} / \mathrm{v}$ de etanol). $n=8$. (A) animais tratados com $100 \mathrm{mg} / \mathrm{kg}$ de extrato; (B) animais tratados com $200 \mathrm{mg} / \mathrm{kg}$ de extrato. 

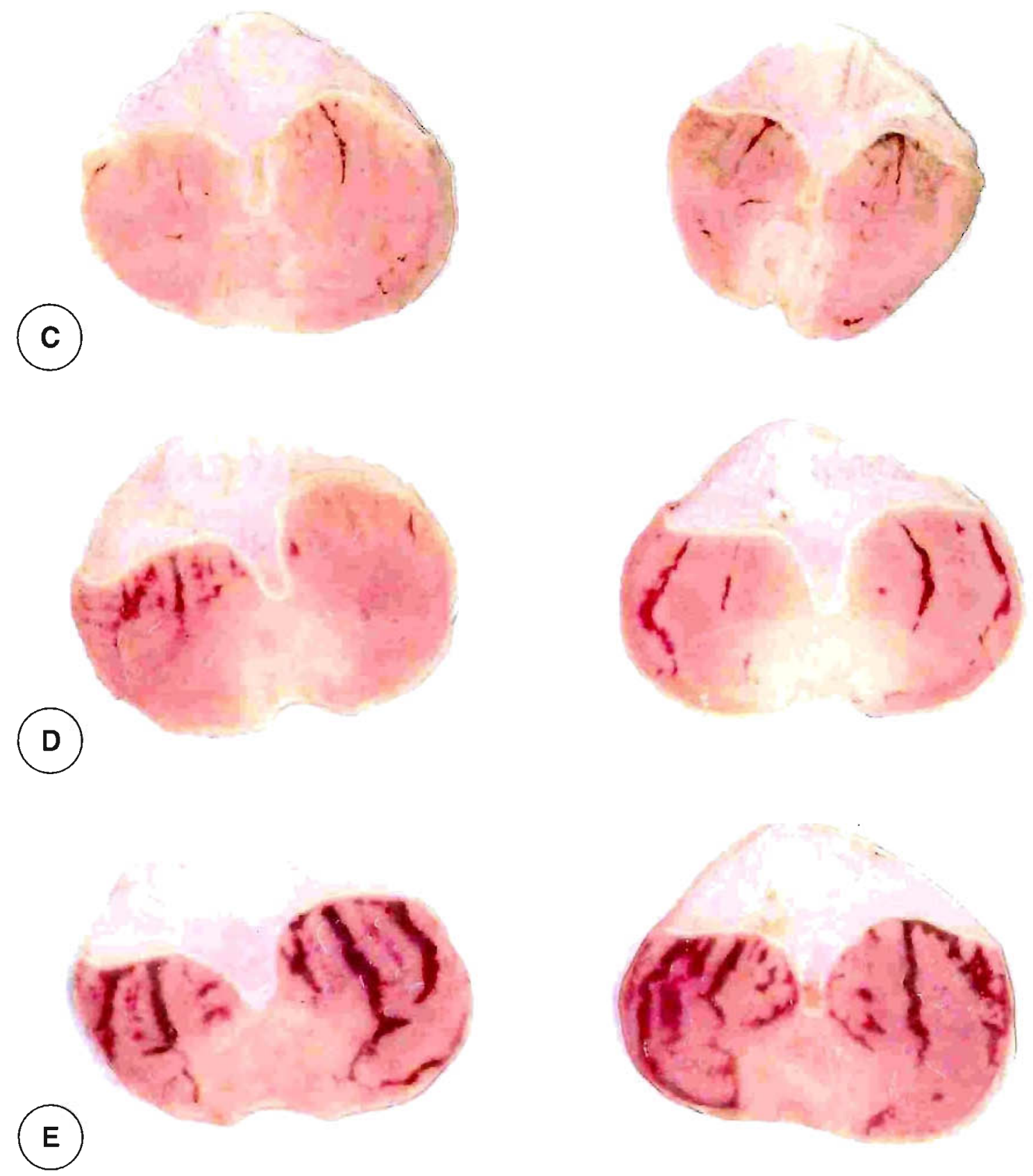

Figura 21. Atividade antiúlcera do extrato liofilizado de Passiflora nitida Kunth. Na figura, em linha horizontal, estão representados 2 estômagos abertos pela curvatura maior, de cada grupo de ratos submetido ao ensaio. Administração intragástrica e indução de úlcera por etanol e ácido clorídrico $(150 \mathrm{mmol} / \mathrm{L}$ de ácido em 60\% v/v de etanol). $\mathrm{n}=8$. (C) animais tratados com $400 \mathrm{mg} / \mathrm{kg}$ de extrato; (D) animais tratados com $30 \mathrm{mg} / \mathrm{kg}$ de lansoprazol; (E) animais tratados com água. 
O resultado da avaliação da atividade antiúlcera gástrica do extrato liofilizado de $P$. nitida, encontra-se na tabela 8 e nas figuras 22 e 23.

Tabela 8. Atividade antiúlcera do extrato liofilizado de Passiflora nitida Kunth. Indução de úlcera por etanol e ácido clorídrico (150 mmol/L de ácido em $60 \% \mathrm{v} / \mathrm{v}$ de etanol).

\begin{tabular}{ccccc}
\hline Área de lesão & $\boldsymbol{P}$. nitida 100 & $\boldsymbol{P}$. nitida 200 & $\boldsymbol{P}$. nitida 400 & Lansoprazol \\
\hline ATL & $25 \%$ & $74 \%^{* *}$ & $94 \%^{* * *}$ & $80 \%^{* * *}$ \\
\hline ARL & $27,40 \%$ & $74,00 \%^{* *}$ & $91,78 \% \%^{* * *}$ & $78,08 \%^{\star *}$ \\
\hline
\end{tabular}

O extrato foi administrado por gavagem nas doses de 100, 200 e 400 mg/kg; lansoprazol na dose de $30 \mathrm{mg} / \mathrm{kg} . \mathrm{n}=8$. ${ }^{* \star} \mathrm{p}<0,01 ;{ }^{* \star *} \mathrm{p}<0,001$. ATL = área total de lesão, em $\mathrm{mm}^{2} ; \mathrm{ARL}=$ área relativa de lesão, em porcentagem.

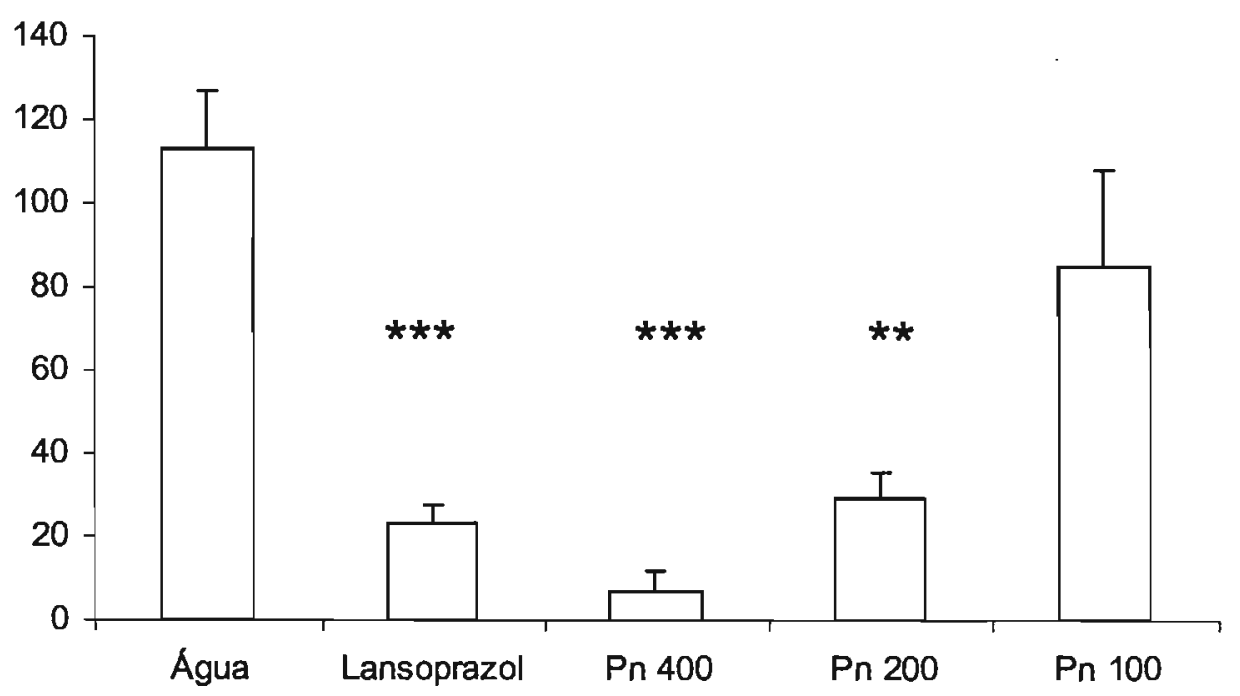

Figura 22. Atividade antiúlcera do extrato liofilizado de Passiflora nitida Kunth. Área total de lesão gástrica (ATL, em $\mathrm{mm}^{2}$ ) induzida por etanol e ácido clorídrico (150 $\mathrm{mmol} / \mathrm{L}$ de ácido em $60 \% \mathrm{v} / \mathrm{v}$ de etanol), em ratos após administração intragástrica. Cada coluna representa a média \pm EPM. $n=8$. ** $p<0,01 ;{ }^{* \star *} p<0,001$. Pn $=$ extrato de Passiflora nitida. Controle positivo = lansoprazol. Controle negativo = água. 


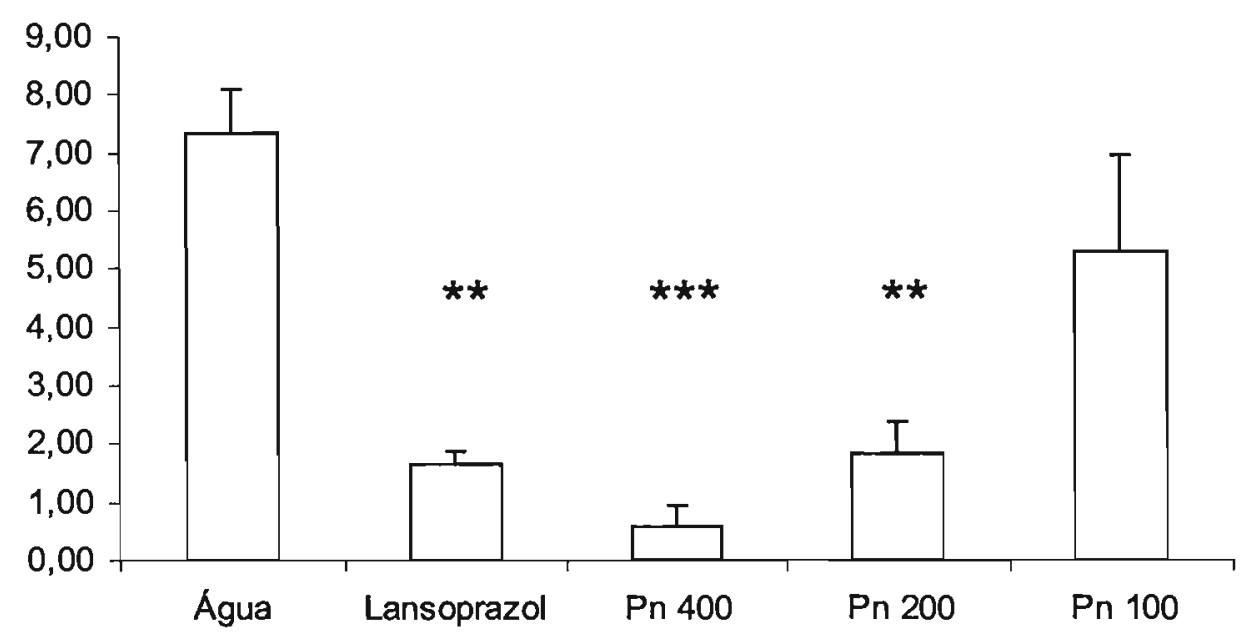

Figura 23. Atividade antiúlcera do extrato liofilizado de Passiflora nitida Kunth. Área relativa de lesão gástrica (ARL, em \%) induzida por etanol e ácido clorídrico (150 $\mathrm{mmol} / \mathrm{L}$ de ácido em $60 \% \mathrm{v} / \mathrm{v}$ de etanol), em ratos após administração intragástrica. Cada coluna representa a média \pm EPM. $n=8 .{ }^{* \star} p<0,01 ;{ }^{\star \star \star} p<0,001$. $P n=$ extrato de Passiflora nitida. Controle positivo $=$ lansoprazol. Controle negativo $=$ água .

Em relação à área total de lesão (ATL), o extrato liofilizado de $P$. nitida exibiu efeito de proteção contra as lesões gástricas de $94 \%$ com $400 \mathrm{mg} / \mathrm{kg}, 74 \%$ com 200 $\mathrm{mg} / \mathrm{kg}, 25 \%$ com $100 \mathrm{mg} / \mathrm{kg}$ e o controle positivo, lansoprazol, de $80 \%$.

Em relação à área relativa de lesão (ARL), o extrato liofilizado de $P$. nitida exibiu efeito de proteção contra as lesões gástricas de $91,78 \%$ com $400 \mathrm{mg} / \mathrm{kg}$; $74,00 \%$ com $200 \mathrm{mg} / \mathrm{kg} ; 27,40 \%$ com $100 \mathrm{mg} / \mathrm{kg}$ e o controle positivo, lansoprazol, de $78,08 \%$.

\subsubsection{Passiflora alata Curtis e Passiflora nitida Kunth}

A figura 24 apresenta os estômagos dos ratos, abertos pela curvatura maior, submetidos ao ensaio da atividade antiúlcera aguda, empregando-se os extratos liofilizados de $P$. alata e $P$. nitida. 
A
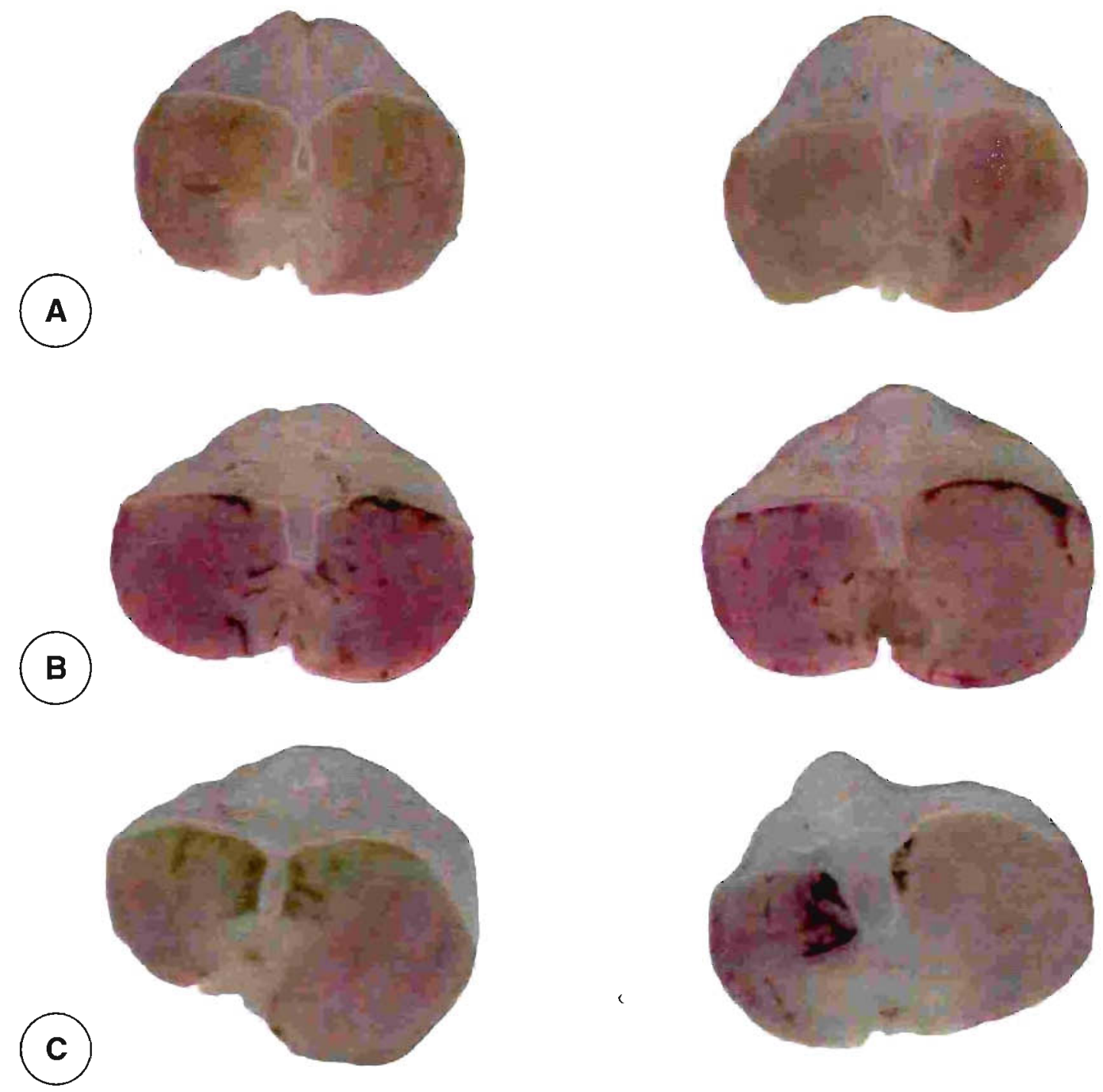

Figura 24. Atividade antiúlcera dos extratos liofilizados de Passiflora alata Curtis e de $P$. nitida Kunth. Na figura, em linha horizontal, estão representados 2 estômagos abertos pela curvatura maior, de cada grupo de ratos submetido ao ensaio. Administração intragástrica e indução de úlcera por etanol e ácido clorídrico (300 $\mathrm{mmol} / \mathrm{L}$ de ácido em $60 \% \mathrm{v} / \mathrm{v}$ de etanol). $\mathrm{n}=8$. (A) animais tratados com $400 \mathrm{mg} / \mathrm{kg}$ de extrato de $P$. alata; (B) animais tratados com $400 \mathrm{mg} / \mathrm{kg}$ de extrato de $P$. nitida; (C) animais tratados com $30 \mathrm{mg} / \mathrm{kg}$ de lansoprazol. 

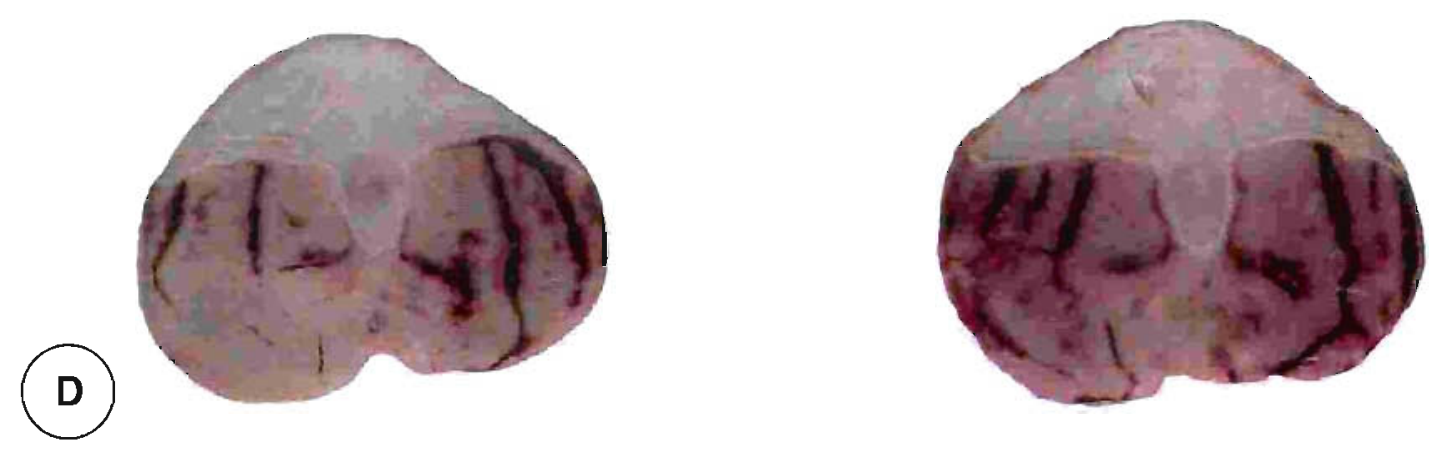

Figura 24. Atividade antiúlcera dos extratos liofilizados de Passiflora alata Curtis e de $P$. nitida Kunth. Na figura, em linha horizontal, estão representados 2 estômagos abertos pela curvatura maior, de cada grupo de ratos submetido ao ensaio. Administração intragástrica e indução de úlcera por etanol e ácido clorídrico (300 $\mathrm{mmol} / \mathrm{L}$ de ácido em $60 \% \mathrm{v} / \mathrm{v}$ de etanol). $\mathrm{n}=8$. (D) animais tratados com água.

O resultado da avaliação da atividade antiúlcera gástrica dos extratos liofilizados de $P$. alata e $P$. nitida, encontra-se na tabela 9 e nas figuras 25 e 26 .

Tabela 9. Atividade antiúlcera dos extratos liofilizados de Passiflora alata Curlis e $P$. nitida Kunth. Indução de úlcera por etanol e ácido clorídrico $(300 \mathrm{mmol} / \mathrm{L}$ de ácido em $60 \%$ v/v de etanol).

\begin{tabular}{cccc}
\hline Área de lesão & Passiflora alata & Passiflora nitida & Lansoprazol \\
\hline ATL & $100 \%^{\star \star \star}$ & $84 \%^{\star \star \star}$ & $76 \%^{\star \star \star}$ \\
\hline ARL & $99,45 \%^{\star \star \star}$ & $82,27 \%^{\star \star \star}$ & $81,44 \%^{\star \star \star}$ \\
\hline
\end{tabular}

O extrato foi administrado por gavagem na dose de $400 \mathrm{mg} / \mathrm{kg}$; lansoprazol na dose de $30 \mathrm{mg} / \mathrm{kg} . n=8$. ${ }^{\star * *} \mathrm{p}<0,001$. $A T L=$ área total de lesão, em $\mathrm{mm}^{2} ; A R L=$ área relativa de lesão, em porcentagem. 


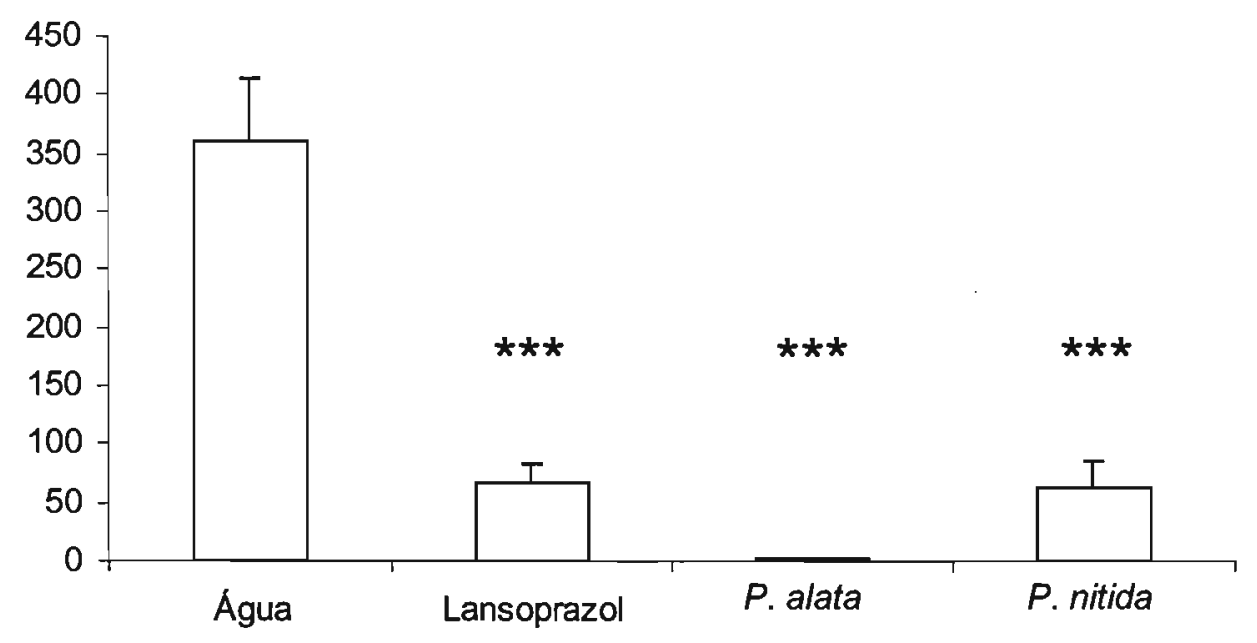

Figura 25. Atividade antiúlcera dos extratos liofilizados de Passiflora alata Curtis e $P$. nitida Kunth. Área total de lesão gástrica (ATL, em $\mathrm{mm}^{2}$ ) induzida por etanol e ácido clorídrico ( $300 \mathrm{mmol} / \mathrm{L}$ de ácido em $60 \% \mathrm{v} / \mathrm{v}$ de etanol), em ratos após administração intragástrica. Extratos administrados na dose de $400 \mathrm{mg} / \mathrm{kg}$. Cada coluna representa a média \pm EPM. $n=8 .{ }^{* \star *} p<0,001$. Controle positivo = lansoprazol. Controle negativo = água. 


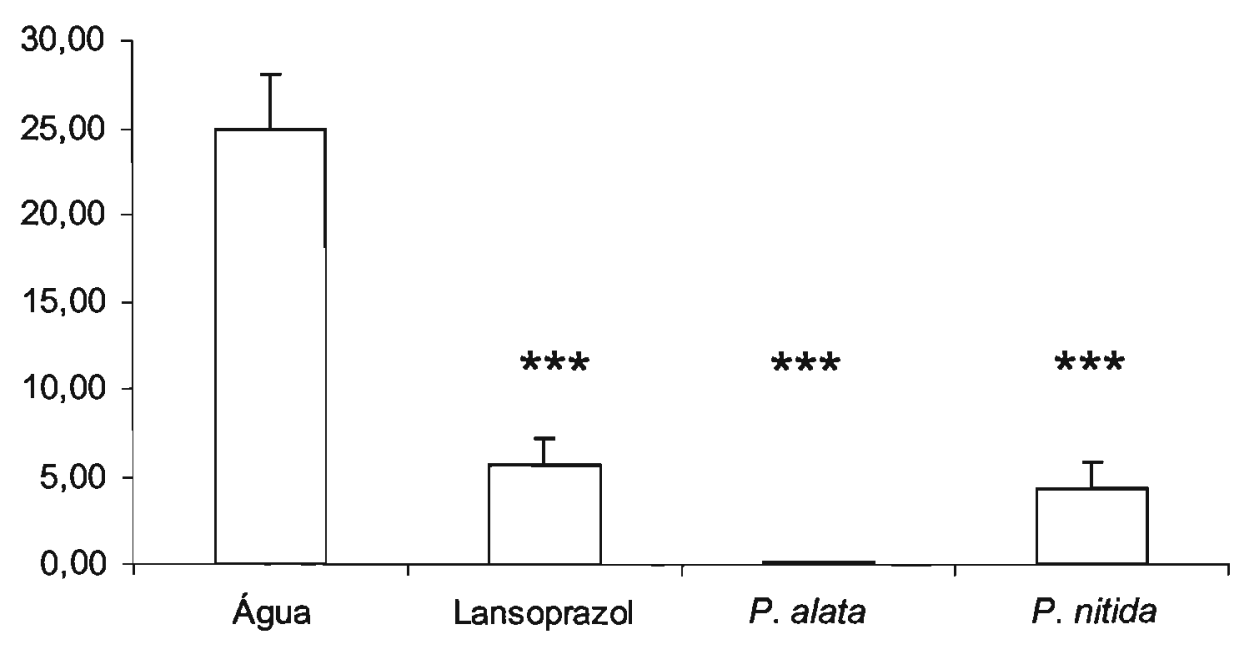

Figura 26. Atividade antiúlcera dos extratos liofilizados de Passiflora alata Curtis e $P$. nitida Kunth. Área relativa de lesão gástrica (ARL, em \%) induzida por etanol e ácido cloridrico (300 mmol/L de ácido em $60 \%$ v/v de etanol), em ratos após adninistração intragástrica. Extratos administrados na dose de $400 \mathrm{mg} / \mathrm{kg}$. Cada coluna representa a média \pm EPM. $n=8$. ${ }^{\star \star \star} p<0,001$. Controle positivo = lansoprazol. Controle negativo = água.

Em relação à área relativa de lesão (ATL), o extrato lioflizado de $P$. alata exibiu efeito de proteção contra as lesões gástricas de $100 \%, P$. nitida de $84 \%$ e o controle positivo, lansoprazol, de $76 \%$.

Em relação à área total de lesão (ARL), o extrato liofilizado de $P$. alata exibiu efeito de proteção contra as lesões gástricas de $99,45 \%$; $P$. nitida de $82,27 \%$ e 0 controle positivo, lansoprazol, de $81,44 \%$. 


\section{Discussão}

Entre as várias plantas utilizadas na medicina popular brasileira para o tratamento de distúrbios gastrintestinais, destacam-se os maracujás, fato que motivou a escolha de espécies do gênero Passiflora. Acrescenta-se o fato de que na literatura internacional pouco enfoque é dado a esta atividade no gênero e poucos trabalhos científicos foram encontrados (MAHADY et al., 2005).

No presente trabalho, intempérie no local de cultivo restringiu o número de espécies disponiveis em quantidade superior a $2000 \mathrm{~g}$ de material seco. Este fator contribuiu para a utilização de órgãos aéreos; não apenas folhas, como consta na Farmacopéia Brasileira para a espécie denominada maracujá. Outro aspecto considerado foi a realidade do mercado de drogas vegetais. Bem conhecida é a dificuldade da obtenção de amostras comerciais constituídas apenas de folhas de maracujá; normalmente encontra-se predominância de caules da espécie. Dentre as primeiras espécies recebidas, foram selecionadas $P$. alata, oficializada pela Farmacopéia Brasileira, e $P$. nitida, morfologicamente semelhante, mas com maior resistência a "pragas".

As semelhanças morfológicas entre estas duas espécies podem levar a fraudes e adulterações da droga vegetal oficial (VEIGA JUNIOR; PINTO; MACIEL, 2005).

O estudo comparativo das duas espécies iniciou-se pela farmacobotânica, concomitantemente à escolha do solvente extrator para o preparo do extrato liofilizado. A seleção do solvente recaiu na mistura que extraiu maior teor de flavonóides, grupo relacionado à atividade antiúlcera (GRACIOSO et al., 2002) e sedativa (DHAWAN; KUMAR; SHARMA, 2001).

No estudo farmacobotânico, as folhas das duas espécies apresentaram semelhança na forma, no tamanho e na ausência de indumento. Diferem quanto ao número de glândulas peciolares. Em $P$. alata observam-se geralmente dois pares de glândulas e em $P$. nitida, um par. Anatomicamente, as duas espécies apresentaram caracteristicas comuns ao gênero Passiflora: mesofilo dorsiventral; drusas no mesofilo, na nervura mediana e, no caule nas regiões cortical, medular e no floema (METCALFE; CHALK, 1950). Embora nas duas espécies a nervura mediana 
encontre-se biconvexa, a de $P$. alata evidencia as carenas pronunciadamente salientes, em forma de $V$, junto à face abaxial. Outro aspecto diferencial observa-se na forma do caule: em $P$. alata é quadrangular e, em $P$. nitida, arredondada. A seqüência de tecidos assemelha-se, com exceção do maior desenvolvimento do colênquima nas arestas de $P$. alata. Comparando-se os resultados obtidos com os reportados por Freitas (1985), na descrição de $P$. alata, observou-se coincidência em grande parte dos resultados. Destaca-se a presença de cristais prismáticos, observados nas dissociações, não reportados em $P$. alata previamente. $P$. nitida também apresentou cristais prismáticos.

A triagem fitoquímica evidenciou a presença de flavonóides nas duas espécies e a ausência de alcalóides em ambas, tanto na droga vegetal quanto nos extratos. A droga vegetal de $P$. alata apresentou a formação de espuma persistente. Já a droga vegetal e o extrato de $P$. alata apresentaram atividade hemolítica. As saponinas não foram quantificadas neste estudo, mas Reginatto e colaboradores (2004) isolaram cinco saponinas de $P$. alata, quantificando uma delas, conhecida como quadrangulosídeo (Figura 6, p. 27), em $0,8 \%$ nas folhas. Este glicosídeo é classificado como uma saponina triterpênica do tipo cicloartano. Na literatura não consta o emprego desta substância em ensaios farmacológicos e não foram encontrados trabalhos que citem a propriedade hemolítica para a droga vegetal ou extratos da espécie.

O cromatograma em camada delgada comparativo evidenciou perfis flavonoídicos da droga vegetal e do extrato liofilizado de $P$. alata distintos dos perfis de $P$. nitida. Rutina, substância de referência, não foi observada na droga ou nos extratos das espécies; trata-se, contudo, de padrão acessivel com valor de Rf (fator de retenção) semelhante ao das principais manchas observadas no cromatograma das espécies (EUROPEAN PHARMACOPOEIA, 2005).

O ensaio da Farmacopéia Européia (EUROPEAN PHARMACOPOEIA, 2005), utilizado na quantificação da fração flavonoídica, não envolve hidrólise ácida uma vez que os flavonóides $C$-glicosídeos, característicos de Passiflora, resistem a tal procedimento. Os flavonóides foram quantificados nas espécies como $0,42 \% \pm 0,01$ em $P$. alata e $0,10 \% \pm 0,01$ em $P$. nitida.

A quantificação dos flavonóides totais de $P$. alata foi realizada, através da mesma metodologia, por Müller e colaboradores (2005). Os autores, empregando o 
mesmo método na quantificação de flavonóides de folhas de $P$. alata, obtiveram $0,470 \% \pm 0,001$ e $0,395 \% \pm 0,0005$ para material coletado no verão e no inverno, respectivamente. Estes teores são semelhantes aos obtidos no presente estudo, no qual, contudo, foram investigados os órgãos aéreos de $P$. alata coletados no verão.

O método do DPPH, utilizado na avaliação da atividade antioxidante, apesar de prático, é considerado preliminar. Na atividade antioxidante, a $E_{50}$ de $P$. alata foi de $1061,2 \pm 8,5 \mu \mathrm{g} / \mathrm{mL}$ e a de $P$. nitida $128,0 \pm 0,9 \mu \mathrm{g} / \mathrm{mL}$. Rutina, utilizada como padrão, apresentou $\mathrm{EC}_{50}$ de $18,3 \pm 0,9 \mu \mathrm{g} / \mathrm{mL}$. Bendini e colaboradores (2006) correlacionam a maior atividade antioxidante de $P$. nitida em relação a outras espécies do gênero à presença de $o$-difenóis e catequinas, não reportados para $P$. alata. Mensor e colaboradores (2001), ao realizarem uma triagem da atividade antioxidante de extratos vegetais de plantas brasileiras, consideraram promissoras as espécies com $\mathrm{EC}_{50}$ de até $200 \mu \mathrm{g} / \mathrm{mL}$.

Okawa e colaboradores (2001), empregando flavonóides isolados de Hordeum vulgare L. var. nudum Spenn. (Poaceae), avaliaram sua atividade antioxidante com DPPH e por ESR (Electron Spin Resonance). Dentre eles, alguns foram identificados em Passiflora: isovitexina, saponarina, diglicosil-4',7-isovitexina e ramnosilglicosil-7-isovitexina. Os valores de $\mathrm{IC}_{50}$ foram, respectivamente, de 1000 $\mu \mathrm{mol} / \mathrm{L}, 211 \mu \mathrm{mol} / \mathrm{L}, 291 \mu \mathrm{mol} / \mathrm{L}$ e $299 \mu \mathrm{mol} / \mathrm{L}$.

Estudos de relação estrutura-atividade de flavonóis revelaram que a presença de o-diidroxilas no anel B é a maior responsável pela atividade antioxidante (YAMAMOTO et al., 1999). Os autores relatam que a atividade antioxidante de derivados da quercetina ensaiados com DPPH demonstra que a estrutura é necessária para a captura de diversos radicais durante a reação. Acresce-se que a capacidade antioxidante da quercetina e de seus derivados é diminuída significativamente pela introdução de um substituinte adicional no anel $\mathrm{B}$, odiidroxilado.

No ensaio de ORAC, ambos os extratos apresentaram atividade antioxidante dependente da concentração. A atividade antioxidante do extrato liofilizado de $P$. alata foi de $1076 \pm 85 \mu \mathrm{mol}$ de Trolox/g de extrato e a atividade antioxidante do extrato liofilizado de $P$. nitida de $1985 \pm 104 \mu \mathrm{mol}$ de Trolox/g de extrato. O extrato de $P$. nitida apresentou maior valor de ORAC que o extrato de $P$. alata. Este resultado confirma o obtido anteriormente para o método de DPPH. Em comparação 
com valores de ORAC obtidos para outros extratos vegetais, ambas as espécies apresentaram resultados promissores (OU; HAMPSCH-WOODILL; PRIOR, 2001).

O método de ORAC, apesar das vantagens sobre outros métodos de avaliação de atividade antioxidante in vitro (HUANG et al., 2002), continua sendo uma ferramenta de avaliação preliminar, auxiliando no rastreamento de extratos vegetais ou substâncias isoladas. Para comprovação da atividade antioxidante de um insumo cosmético, testes mais complexos podem estar envolvidos, como ensaios de permeação cutânea, avaliações de eficácia em cultura de células, assim como testes de segurança.

As úlceras gástricas são doenças que afetam um grande número de pessoas no mundo. Somente nos Estados Unidos da América do Norte cerca de quatro milhões de pessoas apresentam úlceras gástricas ativas e aproximadamente trezentos e cinquenta mil novos casos são diagnosticados todos os anos (SALAS; WARD; CARO, 2002). Alguns dos fatores que aumentam sua incidência são estresse, fumo, deficiências nutricionais e ingestão de antiinflamatórios não esteroidais (BELAICHE et al., 2002).

O mecanismo de gênese da úlcera gástrica ainda não foi completamente elucidado. Acredita-se, no entanto, que a infecção causada pela bactéria Helicobacter pylori está relacionada à manifestação desta patologia. Outro fator determinante no desenvolvimento da doença é o desequilíbrio entre os fatores de proteção e de agressão da mucosa gástrica, entre estes, o próprio $H$. pylori (GOODMAN et al., 2007).

O ácido gástrico é secretado pelas células parietais do estômago pela bomba de prótons e a sua secreção é estimulada por acetilcolina, histamina e gastrina. $O$ lansoprazol inibe a bomba de prótons, considerada a última etapa da secreção ácida. Assim, utilizando o fármaco, o controle da secreção de ácido ocorre independentemente do estímulo nas células. As prostaglandinas estão envolvidas na regulação de uma variedade de funções gastrintestinais, incluindo a circulação sanguínea e a secreção de ácido, muco e bicarbonato. O muco e o bicarbonato liberados pelas células epiteliais fazem parte dos mecanismos de defesa da mucosa gástrica e exercem um importante papel na proteção da mucosa gastroduodenal. Embora a regulação fisiológica da secreção de muco e bicarbonato envolva fatores 
neuronais, a prostaglandina $E_{2}$ é importante no controle local desta secreção (GRACIOSO et al., 2002).

Vários mecanismos têm sido sugeridos para explicar a atividade de compostos antiulcerogênicos, entre eles, o aumento de hexosamina gástrica e da proteção da barreira gástrica, fisicamente ou pelo bloqueio da bomba de prótons (REPETTO; LLESUY, 2002). Di Carlo e colaboradores (1999) salientaram que a geração de radicais livres derivados do oxigênio e a peroxidação lipídica estão entre os mecanismos envolvidos na patogênese da úlcera gástrica.

$\mathrm{Na}$ pesquisa de extratos vegetais com atividade antiúlcera utilizam-se concentrações de até $1000 \mathrm{mg} / \mathrm{kg}$. No entanto, alguns autores sugerem a utilização de concentrações inferiores a 300 ou $400 \mathrm{mg} / \mathrm{kg}$ (BORRELLI; IZZO, 2000). Neste trabalho foi utilizada solução de $400 \mathrm{mg} / \mathrm{kg}$ dos extratos vegetais liofilizados e, a partir dela, foram preparadas soluções de menor concentração.

No ensaio da atividade antiúlcera aguda, $P$. alata exibiu $100 \%$ de proteção, tanto no ensaio que utilizou concentração de $150 \mathrm{mmol} / \mathrm{L}$ de ácido clorídrico para o agente indutor, nas doses de 100, 200 e $400 \mathrm{mg} / \mathrm{kg}$ do extrato liofilizado, quanto no ensaio com $300 \mathrm{mmol} / \mathrm{L}$, na dose de $400 \mathrm{mg} / \mathrm{kg}$. P. nitida apresentou $82 \%$ de proteção no ensaio que utilizou concentração de $300 \mathrm{mmol} / \mathrm{L}$ de ácido clorídrico para o agente indutor, na dose de $400 \mathrm{mg} / \mathrm{kg}$ do extrato liofilizado e $27 \%, 74 \%$ e $92 \%$ de proteção, nas doses de 100, 200 e $400 \mathrm{mg} / \mathrm{kg}$, no ensaio que utilizou $150 \mathrm{mmol} / \mathrm{L}$ de ácido clorídrico, respectivamente. Lansoprazol, a substância de referência, apresentou proteção variando de 75 a $81 \%$ em todos os ensaios realizados.

No ensaio da atividade antiúlcera aguda, a ação das saponinas pode estar relacionada à atividade apresentada pelo extrato liofilizado de $P$. alata. Reginatto e colaboradores (2001) identificaram glicosídeos triterpênicos e esteroidais nas folhas desta espécie. Os autores determinaram, nas folhas, teor de $0,8 \%$ de quadrangulosideo, um glicosídeo triterpênico do tipo cicloartano, em relação à droga vegetal (REGINATTO et al., 2004). Em extrato aquoso das folhas, a substância foi quantificada em $22,2 \%$ pela mesma metodologia empregada para a droga vegetal. Dentre os glicosídeos identificados, o mais abundante na espécie foi o quadrangulosídeo, previamente identificado em $P$. quadrangularis por Orsini e colaboradores (1986), mas até o presente não empregado em ensaios farmacológicos. 
A atividade de saponinas como citoprotetores gástricos é conhecida. Em estudo conduzido por Yoshikawa e colaboradores (2005), os autores observaram que a fração saponínica obtida de sementes de Camellia sinensis (L.) O. Kuntze, Theaceae, exibia proteção contra lesões da mucosa gástrica de ratos, induzidas por etanol e indometacina. Quatro saponinas triterpênicas foram isoladas da fração ativa e exibiram proteção contra lesões da mucosa gástrica na concentração de $5 \mathrm{mg} / \mathrm{kg}$ por via oral. Suas atividades foram mais significativas que a do omeprazol, substância de referência utilizada.

A investigação conduzida por Navarrete e colaboradores (2005) descreve a atividade gastroprotetora do astragalosídeo IV, glicosídeo triterpênico do tipo cicloartano isolado de Astragalus zahlbruckneri (Hand.-Mazz.) Podlech, Fabaceae. Neste ensaio as lesões da mucosa gástrica foram induzidas em ratos por administração intragástrica de etanol (1 $\mathrm{mL}$ por animal). Os ratos que receberam o glicosídeo em concentrações de 3,10 e $30 \mathrm{mg} / \mathrm{kg}$, via oral, apresentaram proteção gástrica de 15, 37 e 52\% em relação ao controle, respectivamente. Carbenoxolona, substância de referência utilizada, administrada nas mesmas doses exibiu efeito protetor de 25,43 e $88 \%$ em relação ao controle.

Da mesma forma, os flavonóides podem estar relacionados ao efeito gastroprotetor apresentado pelos extratos liofilizados das duas espécies. Os flavonóides são reconhecidos por sua atividade antioxidante. Há atualmente um grande interesse no estudo dos radicais livres em sistemas biológicos e seu provável papel na etiologia de diversas doenças crônicas. Ao mesmo tempo, a atenção tem sido direcionada para as funções protetoras de substâncias antioxidantes naturais presentes nas células de diversos organismos (MENSOR et al., 2001; HUNG, 2007).

Extratos vegetais contendo flavonóides podem inibir a atividade da bomba de prótons ou aumentar a secreção de muco e $\mathrm{PGE}_{2}$ (prostaglandina $\mathrm{E}_{2}$ ), o que pode explicar sua atividade antiulcerogênica. Gracioso e colaboradores (2002), investigando a atividade antiúlcera de Turnera ulmifolia L., Turneraceae, através do modelo agudo de indução, identificaram que a atividade estava relacionada à presença de flavonas $\boldsymbol{C}$-glicosiladas derivadas da apigenina e luteolina, presentes na fração ativa.

Os flavonóides, de maneira geral, protegem a mucosa gástrica contra uma série de agentes ulcerogênicos em diferentes espécies de mamíferos. Como 
resultado, muitos estudos tem sido realizados com plantas contendo flavonóides ou a partir de flavonóides sintetizados, para verificar sua atividade antiulcerogênica. Apesar dos resultados promissores, os flavonóides ainda não são explorados comercialmente devido a suas propriedades antiulcerogênicas (GRACIOSO et al., 2002). 


\section{Conclusão}

A atividade antiúlcera aguda foi avaliada pelo método de indução por ácido clorídrico e etanol, utilizando lansoprazol como substância de referência. $P$. alata Curtis e $P$. nitida Kunth apresentaram atividade promissora.

O teor de flavonóides apresentou-se superior em $P$. alata. As duas espécies mostraram atividade antioxidante pelo método empregando DPPH e ORAC.

A caracterização farmacobotânica e a análise cromatográfica em camada delgada permitem distinguir com facilidade as drogas vegetais preparadas com as duas espécies, que apresentam morfológica e anatomicamente caracteres coincidentes ou similares. Dentre os itens diferenciais destacam-se o número de glândulas peciolares, a forma da nervura mediana e do caule em secção transversal. No cromatograma evidencia-se perfil flavonoídico distinto entre as espécies. 


\section{Referências bibliográficas}

AARONS, D.H.; ROSSI, G.V.; ORZECHOWSKI, R.F. Cardiovascular actions of three harmala alkaloids: harmine, harmaline, and harmalol. Journal of Pharmaceutical Sciences, v. 66, p. 1244-1248, 1977.

ABOURASHED, E.A.; VANDERPLANK, J.R.; KHAN, I.A. High-speed extraction and HPLC fingerprinting of medicinal plants. I. Application to Passiflora flavonoids. Pharmaceutical Biology, v. 40, p. 81-91, 2002.

ABOURASHED, E.A.; VANDERPLANCK, J.R.; KHAN, I.A. High-speed extraction and HPLC fingerprinting of medicinal plants. II. Application to harman alkaloids of genus Passiflora. Pharmaceutical Biology, v. 41, p. 100-106, 2003.

ANDERSEN, A.; BRIMER, L.; OLSEN, C.E.; JAROSZEWSKI, J.W. Cyanogenesis of Passiflora colinvauxii, a species endemic to the Galapagos Islands. Phytochemistry, v. 33, p. 365-367, 1993.

ANDERSEN, L.; ADSERSEN, A.; JAROSZEWSKI, J.W. Cyanogenesis of Passiflora foetida. Phytochemistry, v. 47, p. 1049-1050, 1998.

BRASIL. Ministério da Saúde. Agência Nacional de Vigilância Sanitária. Serviço de Busca Interna do Site. Disponivel em: http://www.anvisa.gov.br/busca/busca.asp. Acesso em: 29 nov. 2006.

AOYAGI, N.; KIMURA, R.; MURATA, T. Passiflora incarnata dry extract. I. Isolation of maltol and pharmacological action of maltol and ethyl maltol. Chemical and Pharmaceutical Bulletin, v. 22, p. 1008-1013, 1974.

BALBACHAS, A. As plantas curam. 6. ed. São Paulo: Editora Missionária "A Verdade Presente", 1957. 432p.

As referências bibliográficas estão de acordo com a norma NBR6023/2002 preconizada pela Associação Brasileira de Normas Técricas (ABNT). 
BALUNAS, M.J.; KINGHORN, A.D. Drug discovery from medicinal plants. Life Sciences, v. 78, p. 431-441, 2005.

BARROSO, G.M. Sistemática de angiospermas do Brasil. Viçosa: Editora Universitária de São Paulo, 1978. v. 1. 225p.

BELAICHE, J.; BURETTE, A.; DE VOS, M.; LOUIS, E.; HUYBRECHTS, M.; DELTENRE, M. Observational survey of NSAID-related upper gastro-intestinal adverse events in Belgium. Acta Gastroenterology Belgium, v. 65, p. 65-73, 2002.

BENDINI, A.; CERRETANI, L.; PIZZOLANTE, L.; TOSCHI, T.G.; GUZZO, F.; CEOLDO, S.; MARCONI, A.M.; ANDREETTA, F.; LEVI, M. Phenol content related to antioxidant and antimicrobial activities of Passiflora spp. extracts. European Food Research and Technology, v. 223, p. 102-109, 2006.

BENNATI, E. Identification, by thin-layer chromatography, of liquid extract of Passiflora incarnata. Bollettino Chimico Farmaceutico, v. 106, p. 756-760, 1967.

BENNATI, E.; FEDELI, E. Gas chromatography of fluid extract of Passiflora incarnata. Bollettino Chimico Farmaceutico, v. 107, p. 716-720, 1968.

BENNATI, E. Quantitative determination of harmane and harmine in the extract of Passiflora incarnata. Bollettino Chimico Farmaceutico, v. 110, p. 664-669, 1971.

BERLYN, G.P.; MIKSCHE, J.P. Botanical microtechnique and cytochemistry. Ames: lowa State University Press, 1976.

BERNACCI, L.C. Passifloraceae. In: WANDERLEY, M.G.L.; SHEPHERD, G.J.; GIULIETTI, A.M.; MELHEM, T.S. (coord.) Flora Fanerogâmica do Estado de São Paulo. São Paulo: RiMa/FAPESP, 2003. v. 3, p. 247-248.

BIRK, C.D.; PROVENSI, G.; REGINATTO, F.H.; SCHENKEL, E.P.; GOSMANN, G.TLC Fingerprint of flavonoids and saponins from Passiflora species. Journal of Liquid Chromatography \& Related Technologies, v. 28, p. 2285-2291, 2005. 
BOKSTALLER, S.; SCHMIDT, P.C. A comparative study on the content of passionflower flavonoids and sesquiterpenes from valerian root extracts in pharmaceutical preparations by HPLC. Pharmazie, v. 52, p. 552-557, 1997.

BOMBARDELLI, E; BONATI, A.; GABETTA, B.; MARTINELLI, E.M.; MUSTICH, G.; DANIELI, B. Passiflorine, a new glycoside from Passiflora edulis. Phytochemistry, $v$. 14, p. 2661-2665, 1975.

BORGATTI, G. Pharmacodynamic studies on Passiflora incarnata L. Bollettino della Società Italiana di Biologia Sperimentale, v. 14, p. 203-205, 1939.

BORRELLI, F.; PINTO, L.; IZZO, A.A.; MASCOLO, N.; CAPASSO, F.; MERCATI, V.; TOJA, E.; AUTORE, G. Anti-inflammatory activity of Passiflora incarnata L. in rats. Phytotherapy Research, v. 10, p. S104-106, 1996.

BORRELLI, F.; IZZO, A.A. The plant kingdom as a source of anti-ulcer remedies. Phytotherapy Research, v. 14, p. 581-591, 2000.

BRAGA, M.F.; JUINQUEIRA, N.T.V.; FALEIRO, F.G.; BELLON, G.; JUNQUEIRA, K.P. Maracujá-doce: melhoramento genético e germoplasma. p. 601-616. In: Maracujá: germoplasma e melhoramento genético. FALEIRO, F.G.; JUNQUEIRA, N.T.V.; BRAGA, M.F. (eds.) Planaltina, DF: Embrapa Cerrados, 2005. 670p.

BRUNETON, J. Pharmacognosy, phytochemistry, medicinal plants. 2. ed. Paris: Intercept, 1999. 333p.

CERVI, A.C. Passifloraceae do Brasil: estudo do gênero Passiflora L., subgênero Passiflora. FontQueria, v. 45, p. 1-92, 1997.

CHASSAGNE, D.; CROUZET, J.; BAYONOVE, C.L.; BRILLOUT, J.N.; BAUMES, R.L. 6-O- $\alpha$-L-arabinopyranosyl- $\beta$-D-glucopyranosides as aroma precursors from passion fruit. Phytochemestry, v. 41, p. 1497-1500, 1996.

CHASSAGNE, D.; CROUZET, J. A cyanogenic glycoside from Passiflora edulis fruits. Phytochemistry, v. 49, p. 757-759, 1998. 
CHOUDHURI, S.; VALERIO JR., L.G. Usefulness of studies on the molecular mechanism of action of herbals/botanicals: the case of St. John's wort. Journal of Biochemical and Molecular Toxicology, v. 19, p. 1-11, 2005.

CORREAA, M.P. Dicionário das plantas úteis do Brasil e das exóticas cultivadas. Rio de Janeiro: Imprensa Nacional. v. 5, p. 108, 1984.

DELLA LOGGIA, R. Piante officinali per infusi e tisane. Milano: Organizzazione Editoriale Medico Farmaceutica, 1993.

DE-PARIS, F.; PETRY, R.D.; REGINATTO, F.H.; GOSMANN, G.; QUEVEDO, J.; SALGUEIRO, J.B.; KAPCZINSKI, F.; GONZÁLEZ-ORTEGA, G.; SCHENKEL, E.P. Pharmacochemical study of aqueous extracts of Passiflora alata Dryander and Passiflora edulis Sims. Acta Farmacéutica Bonaerense, v. 21, p. 5-8, 2002.

DERMARDEROSIAN, A., BEUTLER, J.A. (eds.) The Review of Natural Products. Saint Louis: Facts and Comparisons, 2002.

DHAWAN, K.; KUMAR, S.; SHARMA, A. Anti-anxiety studies on extracts of Passiflora incarnata Linneaus. Journal of Ethnopharmacology, v. 78, p. 165-170, 2001.

DHAWAN, K.; DHAWAN, S.; SHARMA, A. Passiflora: a review update. Journal of Ethnopharmacology, v. 94, p. 1-23, 2004.

DI CARLO, G.; MASCOLO, N.; IZZO, A.A.; CAPASSO, F. Flavonoids: old and new aspects of a class of natural therapeutic drugs. Life Sciences, v. 65, p. 337-353, 1999.

DOYAMA, J.T.; RODRIGUES, H.G.; NOVELLI, E.L.B.; CEREDA, E.; VILEGAS, W. Chemical investigation and effects of the tea of Passiflora alata on biochemical parameters in rats. Journal of Ethnopharmacology, v. 96, p. 371-374, 2005.

DUKE, J.A. The Green Pharmacy. Emmaus: Rodale Press, 1997.

DUKE, J.A. Handbook of medicinal herbs. 2. ed. Boca Raton: CRC Press, 2002. $870 p$. 
ESCOBAR, L.K.; LIUT, Y.; MABRY, T.J. C-glycosylflavonoids from Passiflora coactilis. Phytochemistry, v. 22, p. 796-797, 1983.

EUROPEAN Pharmacopoeia. 5. ed. Strasbourg: Council of Europe, 2005. v. 2, p. 2192-2193.

FARMACOPÉIA Brasileira. 3. ed. São Paulo: Andrei, 1977. 1213p.

FARMACOPÉIA Brasileira. 4. ed. São Paulo: Atheneu, 1988. pt. 1.

FARMACOPÉIA dos Estados Unidos do Brasil. 2. ed. São Paulo: Gráfica Siqueira, 1959. 606p.

FELIPPE, G.; TOMASI, M.C. Frutas: Sabor à Primeira Dentada. São Paulo: SENAC, 2005. 302p.

FELLOWS, E.J.; SMITH, C.S. The chemistry of Passiflora incarnata. Journal of the American Pharmacists Association, v. 27, p. 574-576, 1938.

FERREIRA, F.R.; OLIVEIRA, J.C. Germoplasma de Passiflora. In: SÃO JOSÉ, A.R. A cultura do maracujá no Brasil. Jaboticabal, FUNEP, 1991, p. 187-200.

FISCHER, F.C.; FUNG, S.Y.; LANKHORST, P.P. Cyanogenic compounds from Passiflora capsularis, $P$. warmingii and $P$. perfoliata. Planta Medica, v. 45, p. 42-45, 1982.

FOSTER, A.S. Practical plant anatomy. 2. ed. Princeton: D. van Nostrand, 1949.

FRANKLIN, G.L. Preparation of thin sections of synthetic resins and wood-resin composites and a new macerating method for wood. Nature, v. 55, p. 51, 1945.

FREITAS, P.C.D. Estudo farmacognóstico comparativo de espécies brasileiras do gênero Passiflora L. São Paulo, 1985. Dissertação de Mestrado - Faculdade de Ciências Farmacêuticas - Universidade de São Paulo. 
GARCIA, A.A. Fitoterapia: Vademécum de Prescripción. 3. ed. Barcelona: Masson, 2000. 1148p.

GAVASHELI, N.M.; MONIAVA, I.I.; ERISTAVI, L.I. Flavonoids from Passiflora incarnata. Khimiya Prirodnykh Soedinenii, v. 10, p. 95-96, 1974.

GEIGER, H.; MARKHAM, K.R. The C-glycosylflavone pattern of Passiflora incarnata L. Zeitschrift für Naturforschung Teil C, v. 41, p. 949-950, 1986.

GLOTZBACH, B.; RIMPLER, H. Die Flavonoide von Passiflora incarnata L., Passiflora quadrangularis L. und Passiflora pulchella H.B.K. Planta Medica, v. 16, p. 1-7, 1968.

GOODMAN, L.S.; HARDMAN, J.G.; LIMBIRD, L.E.; GILMAN, A.G. Goodman \& Gilman as bases farmacológicas da terapêutica. 11. ed. Rio de Janeiro: McGrawHill, 2007. 1821p.

GRACIOSO, J.S.; VILEGAS, W.; HIRUMA-LIMA, C.A.; SOUZA BRITO, A.R.M. Effects of tea from Turnera ulmifolia $L$. on mouse gastric mucosa support the Turneraceae as a new source of antiulcerogenic drugs. Biological Pharmaceutical Bulletin, v. 25, p. 487-491, 2002.

GRIEVE, M.; LEYEL, C. F. A modern herbal. London: Tiger Books International, 1994.

HALE, E.M. Materia medica and special therapeutics of the new remedies. 4 ed. New York, Philadelphia, 1875 apud NEUGEBAUER, H. Zur Kenntnis der sedativ wirkenden Inhaltstoffe von Passiflora. Pharmazie, v. 4, n. 4, p. 176-178, 1949.

HARBORNE, J.B. Twenty-five years of chemical ecology. Natural Product Reports, vol. 18, p. 361-379, 2001.

HEGNAUER, R. Chemotaxonomie der Pflanzen. Basel, Stuttgart: Birkhäuser Verlag, 1990.

HOSTETTMANN, K.; MARSTON, A. Saponins. Cambridge: Cambridge University Press, 1995. 
HUANG, D.; OU, B.; HAMPCH-WOODILL, M.; FLANAGAN, J.A.; PRIOR, R. Highthroughput assay of oxygen radical aborbance capacity (ORAC) using a multichannel liquid handling system coupled with a microplate fluorescence reader in 96-well format. Journal of Agricultural and Food Chemistry, n. 50, p. 4437-4444, 2002.

HUNG, H. Dietary quercetin inhibits proliferation of lung carcinoma cells. Forum of nutrition, v. 60, p. 146-157, 2007.

JAROSZEWSKI, J.W.; FOG, E. Sulphate esthers of cyclopentenoid cyanohydrin glycosides. Phytochemistry, v. 28, p. 1527-1528, 1989.

JAROSZEWSKI, J.W.; OLAFSDOTTIR, E.S.; WELLENDORPH, P.; CHRISTENSEN, J.; FRAZYK, H.; SOMANADHAN, B.; BUDNIK, B.A.; JØRGENSEN, L.B.; CLAUSEN, $\checkmark$. Cyanohydrin glycosides of Passiflora: distribution pattern, a saturated cyclopentane derivative from $P$. guatemalensis, and formation of pseudocyanogenic a-hydroyamides as isolation artefacts. Phytocemistry, n. 59, p. 501-511, 2002.

JOHANSEN, D.A. Plant microtechnique. New York: McGraw-Hill, 1940.

JOLY, A.B. Botânica: introdução à taxonomia vegetal. 7. ed. São Paulo: Nacional, 1985. 778p.

JUDD, W.S. Plant systematics: a phylogenetic approach. Sunderland: Sinauer Associates, 1999. 464p.

KRUGER, A. Herbs: their medicine and magic. London: Parkgate Books, 1992.

LÖHDEFINK, V.J.; KATING, H. Zur frage des Vorkommens von Harmanalkaloiden in Passiflora-Arten. Planta Medica, v. 25, p. 101-104, 1974.

LUTOMSKI, J. Qualitative and quantitative chromatographic investigations of alkaloids of Passiflora incarnata. Biuletyn Instytutu Roslin Leczniczych, v. 5, p. 182-198, 1959.

LUTOMSKI, J. Isolation of the major alkaloids from Passiflora incarnata. Biuletyn Instytutu Roslin Leczniczych, v. 6, p. 209-219, 1960. 
LUTOMSKI, J.; WROCINSKI, T. Pharmacodinamic properties of $P$. incarnata preparations. The effect of alkaloid and flavonoid components on pharmacodinamic properties of the raw materials. Biuletyn Instytutu Roslin Leczniczych, v. 6, p. 176$184,1960$.

LUTOMSKI, J.; KOWALEWSKI, Z.; DROST, K.; SCHMIDT, K. Simple carboline alkaloids I. Thin-layer chromatography of harman alkaloids occurring in plant material and in preparations. Herba Polonica, v. 13, p. 44-52, 1967.

LUTOMSKI, J.; ADAMSKA, M.; JARUZELSKI, M. Simple carboline alkaloids V. Comparative analysis of basic components of Passiflora incarnata from glasshouse and ground culture. Herba Polonica, v. 14, p. 139-147, 1968.

LUTOMSKI, J.; MALEK, B. Pharmacochemical investigations on raw materials genus Passiflora. 3. Phytochemical investigations on raw materials of Passiflora edulis forma flavicarpa. Planta Medica, v. 27, p. 222-225, 1975.

LUTOMSKI, J.; MALEK, B.; RYBACKA, L. Pharmacochemical investigation of the raw materials from Passiflora genus. Planta Medica, v. 27, p. 112-121, 1975.

LUTOMSKI, J.; MALEK, B. Phytochemical studies of drugs from Passiflora edulis Sims. forma flavicarpa. Herba Hungarica, v. 15, p. 7-11, 1976.

MAHADY, G.B.; PENDLAND, S.L.; STOIA, A.; HAMILL, F.A.; FABRICANT, D.; DIETZ, B.M.; CHADWICK, L.R. In vitro susceptibility of Helicobacter pylori to botanical extracts used traditionally for the treatment of gastrointestinal disorders. Phytotherapy Research, v. 19, p. 988-991, 2005.

MAHMMOUD, Y.A. Modulation of protein kinase $C$ by curcumin; inhibition and activation switched by calcium ions. British Journal of Pharmacology, v. 150, p. 200-208, 2007.

MALUF, E.; BARROS, H.M.T.; FROCHTENGARTEN, M.L.; BENTI, R.; LEITE, J.R. Assessment of the hypnotic/sedative effects and toxicity of Passiflora edulis aqueous extract in rodents and humans. Phytotherapy Research, v. 5, p. 262-266, 1991. 
MARECK, U.; HERRMANN, K.; GALENSA, R.; WRAY, V. The 6-C-chinovoside and 6-C-fucoside of luteolin from Passiflora edulis. Phytochemistry, v. 30, p. 3486-3487, 1991.

MARTENS, S.; MITHÖFER, A. Flavones and flavone synthases. Phytochemistry, v. 66, p. 2399-2407, 2005.

McCORMICK, S.; MABRY, T.J. The flavonoids of Passiflora pavonis. Journal of Natural Products, v. 44, p. 623, 1981.

McCORMICK, S.; MABRY, T.J. The flavonoids of Passiffora sexflora. Journal of Natural Products, v. 45, p. 782, 1982.

McGUIRE, W.P. The story of taxol. Science, v. 292.5519, p. 1073, 2001.

MEDEIROS, R.; PASSOS, G.F.; VITOR, C.E.; KOEPP, J.; MAZZUCO, T.L.; PIANOWSKI, L.F.; CAMPOS, M.M.; CALIXTO, J.B. Effect of two active compounds obtained from the essential oil of Cordia verbenacea on the acute inflammatory responses elicited by LPS in the rat paw. British Journal of Pharmacology, v. 151, p. 618-627, 2007.

MEDINA, J.H.; PALADINI, A.C.; WOLFMAN, C.; DE STEIN, M.L.; CALVO, D.; DIAZ, L.E.; PEÑA, C. Chrysin (5,7-di-OH-flavone), a naturally occurring ligand for benzodiazepine receptors, with anticonvulsant properties. Biochemistry and Pharmacology, v. 40, p. 2227-2231, 1990.

MELETTI, L.M.M.; MAIA, M.L. Maracujá: produção e comercialização. Boletim Técnico Instituto Agronômico, v. 181, p. 1-64, 1999.

MENGHINI, A.; MANCINI, L.A. TLC determination of flavonoid accumulation in clonal populations of Passiflora incarnata L. Pharmacological Research Cornmunications, v. 20, p. 113-116, 1988.

MENSOR, L.L.; MENEZES, F.S.; LEITÃO, G.G.; REIS, A.S.; SANTOS, T.C.; COUBE, C.S.; LEITÃO, S.G. Screening of Brazilian plant extracts for antioxidant activity by the use of DPPH free radical method. Phytotherapy Research, v. 15, p. 127-130, 2001. 
METCALFE, C.R.; CHALK. L. Anatomy of dicotyledons: leaves, stem, and wood in relation to taxonomy with notes on economic uses. Oxford: Claredon Press, 1950. v. 1.

MIZUI, T.; DOTEUCHI, M. Effect of polyamines on acidified ethanol-induced gastric lesions in rats. Japanese Journal of Pharmacology, v. 33, p. 939-945, 1983.

MORAES, M.L.L. Extração e análise de flavonóides em espécies brasileiras de Passiflora L. São Carlos, 1995. Dissertação de Mestrado - Instituto de Química de São Carlos - Universidade de São Paulo.

MORAES, M.C.; VIEIRA, M.L.C.; NOVAES, Q.S.; REZENDE, J.A.M. Susceptibilidade de Passiflora nitida ao passion fruit woodiness virus. Fitopatologia Brasileira, v. 27, 2002.

MÜLLER, S.D.; VASCONCELOS, S.B.; COELHO, M.; BIAVATTI, M.W. LC and UV determination of flavonoids from Passiflora alata medicinal extracts and leaves. Journal of Pharmaceutical and Biomedical Analysis, v. 37, p. 399-403, 2005.

NAVARRETE, A.; ARRIETA, J.; TERRONES, L.; ABOU-GAZAR, H.; CALIS, I. Gastroprotective effect of Astragaloside IV: role of prostaglandins, sulfhydryls and nitric oxide. Journal of Pharmacy and Pharmacology, v. 57, p. 1059-1064, 2005.

NEU, R. Inhaltsstoffe der Passiflora incarnata. 1. Mitteilung: The insoluble parts of lipoid extracts in alkalis. Arzneimittelforschung, v. 4, p. 292-294, 1954a.

NEU, R. Inhaltsstoffe der Passiflora incarnata. 2. Mitteilung: Über basische Anteile. Arzneimittelforschung, v. 4, p. 601-606, 1954b.

NEU, R. Inhaltsstoffe der Passiflora incarnata, 3. Mitteilung: 3-methyl-4-carbolin (2'methyl-(pyridino-3', 4':2,3-indol)), das Alkaloid der Passifloren. Arzneimittelforschung, v. 6, p. 94-99, 1956.

NEUGEBAUER, H. Zur Kenntnis der sedativ wirkenden Inhaltstoffe von Passiflora. Pharmazie, v. 4, n. 4, p. 176-178, 1949. 
NEWMAN, D.J.; CRAGG, G.M.; SNADER, K.M. Natural products as sources of new drugs over the period 1981-2002. Journal of Natural Products, v. 66, p. 1022-1037, 2003.

OGA, S.; FREITAS, P.C.D.; SILVA, A.C.G.; HANADA, S. Pharmacological trials of crude extract of Passiflora alata. Planta Medica, v. 51, p. 303-306, 1984.

OKAWA, M.; KINJO, J.; NOHARA, T.; ONO, M. DPPH (1,1-diphenyl-2-picrylhydrazyl) radical scavenging activity of flavonoids obtained from some medicinal plants. Biological and Pharmaceutical Bulletin, v. 24, n. 10, p. 1202-1205, 2001.

OLAFSDOTTIR, E.S.; ANDERSEN, J.V.; JAROSZEWSKI, J.W. Cyanohydrin glycosides of Passifloraceae. Phytochemistry, v. 28, p. 127-132, 1989.

OLAFSDOTTIR, E.S.; JAROSZEWSKI, J.W.; SEIGLER, D.S. Cyanohydrin glycosides with unusual sugar residues: revised structure of passitrifasciatin. Phytochemistry, v. 30, p. 867-869, 1991.

ORSINI, F.; VEROTTA, L. Separation of natural polar substances by reversed-phase high-performance liquid chromatography, centrifugal thin-layer chromatography and droplet counter-current crmaography. Journal of Chromatography, v. 349, p. 69-75, 1985.

ORSINI, F.; PELIZZONI, F.; VEROTTA, L. Quadranguloside, a cycloartane triterpene glycoside from Passiflora quadrangularis. Phytochemistry, v. 25, p. 191-193, 1986.

ORSINI, F.; PELIZZONI, F.; RICCA, G.; VEROTTA, L. Triterpene glycosides related to quadranguloside from Passiflora quadrangularis. Phytochemistry, v. 26, p. 1101$1105,1987$.

OSORIO, C.; DUQUE, C.; FUJIMOTO, Y. Oxygenated monoterpenoids from badea (Passiflora quadrangularis) fruit pulp. Phytochemistry, v. 53, p. 97-101, 2000.

OU, B.; HAMPSCH-WOODILL, M.; PRIOR, R.L. Development and validation of an improved oxygen radical absorbance capacity assay using fluorescein as the fluorescent probe. Journal of Agricultural and Food Chemistry, n. 49, p. 46194626, 2001. 
PARR, A.J.; BOLWELL, G.P. Phenols in the plant and in man. The potential for possible nutritional enhancement of the diet by modifying the phenols content or profile. Journal of the Science of Food and Agriculture, v. 80, p. 985-1012, 2000.

PASTENE, E.; MONTES, M.; VEGA, M. New HPTLC method for quantitative analysis of flavonoids of Passiflora caerulea L. Journal of Planar Chromatography - Modern TLC, v. 10, p. 362-367, 1997.

PDR for herbal medicines. 2. ed. Montvale: Medical Economics Company, 2000. 860p.

PECKOLT, TH. Heil und Nutzpflanzen Brasiliensis. Passifloraceae. Berichte der Deutschen Pharmazeutischen Gesellschaft, v. 19, p. 343- 361, 1909.

PEIXOTO, M. Problemas e perspectives do maracujá ornamental. p. 457-463. In: Maracujá: germoplasma e melhoramento genético. FALEIRO, F.G.; JUNQUEIRA, N.T.V.; BRAGA, M.F. (eds.) Planaltina, DF: Embrapa Cerrados, 2005. 670p.

PEREIRA, S.J.; MUÑIZ, G.I.B.; NISGOSKI, S.; CECCANTINI, G. Morfologia e densidade básica das folhas de tucum (Bactris inundata Martius) como fonte de fibras celulósicas para papel. Ciência Florestal, v. 12, p. 39-48, 2002.

PETRY, R.D.; REGINATTO, F.; DE-PARIS, F.; GOSMANN, G.; SALGUEIRO, J.B.; QUEVEDO, J.; KAPCZINSKI, F.; ORTEGA, G.G.; SCHENKEL, E.P. Comparative pharmacological study on hydroethanol extracts of Passiflora alata and Passiflora edulis leaves. Phytotherapy Research, v. 15, p. 162-164, 2001.

PIETTA, P.G.; MAURI, P.L.; MANERA, E.; CEVA, P.L.; RAVA, A. An improved HPLC determination of flavonoids in medicinal plant extracts. Chromatographia, v. 27, p. 509-512, 1989.

PINK, R.; HUDSON, A.; MOURIĖS, M.A.; BENDIG, M. Opportunities and challenges in antiparasitic drug discovery. Nature reviews: drug discovery, v. 4, p. 727-740, 2005. 
PLOTZE, R.O.; FALVO, M.; PADUA, J.G.; BERNACCI, L.C.; VIEIRA, M.L.C.; OLIVEIRA, G.C.X.; BRUNO, O.M. Leaf shape analysis using the multiscale Minkowski fractal dimension, a new morphometric method: a study with Passiflora (Passifloraceae). Canadian Journal of Botany, v. 83, p. 287-301, 2005.

POETHKE, V.W.; SCHWARZ, C.; GERLACH, H. Substances of Passiflora incarnata L. (Constituents of Passiflora bryonioides). Alkaloids. Planta Medica, v. 18, p. 303314, 1970.

QIMIN, L.; VAN DEN HEUVEL, H.; DELORENZO, O.; CORTHOUT, J.; PIETERS, L.A.C.; VLIETINCK, A.J.; CLAEYS, M. Mass spectral characterization of $C$-glycosidic flavonoids isolated from a medicinal plant (Passiflora incarnata). Journal of Chromatography, v. 562, p. 435-446, 1991.

RADFORD, A.E. Fundamentals of plant systematics. New York: Harper \& Row Publishers, 1986.

RAHMAN, K.; KRENN, L.; KOPP, B.; SCHUBERT-ZSILAVECZ, M.; MAYER, K.K.; KUBELKA, W. Isoscoparin-2"-O-glucoside from Passiflora incarnata. Phytochemistry, v. 45, p. 1093-1094, 1997.

REGINATTO, F.H.; KAUFFMANN, C.; SCHRIPSEMA, J.; GUILLAUME, D.; GOSMANN, G.; SCHENKEL, E.P. Steroidal and triterpenoidal glucosides from Passiflora alata. Journal of the Brazilian Chemical Society, v. 12, p. 32- 36, 2001.

REGINATTO, F.; KAUFFMAN, C.; SCHRIPSEMA, J.; GOSMANN G.; SCHENKEL, E.P. Assay of quadranguloside, the major saponin of leaves of Passiflora alata, by HPLC-UV. Phytochemical Analysis, v. 15, p. 195-197, 2004.

REHWALD, A; MEIER, B.; STICHER, O. Qualitative and quantitative reversed-phase high-performance liquid chromatography of flavonoids in Passiflora incarnata L. Pharmaceutica Acta Helvetiae, v. 69, p. 153-158, 1994.

REHWALD, A.; STICHER, O.; MEIER, B. Trace analysis of harman alkaloids in Passiflora incarnata by reversed-phase high performance liquid chromatography. Phytochemical Analysis, v. 6, p. 96-100, 1995. 
REPETTO, M.G.; LLESUY, S.F. Antioxidant properties of natural compounds used in popular medicine for gastric ulcer. Brazilian Journal of Medical and Biological Research, v. 35, p. 523-534, 2002.

ROESER, K.R. Die Nadel der Schwarkiefer-Massenprodukt und Kunstwerk der Natur. Mikrokosmos, v. 61, p. 33-36, 1962.

ROMMELSPACHER, H.; NANZ, C.; BORBE, H.O.; FEHSKE, K.J.; MÜLLER, W.E.; WOLLERT, U. 1-Methyl-beta-carboline (harmane), a potent endogenous inhibitor of benzodiazepine receptor-binding. Naunyn-Schmiedenberg's Archives of Pharmacology, v. 314, p. 97-100, 1980.

RUGGY, G.H.; SMITH, C.S. A pharmacological study of the active principle of Passiflora incarnata. Journal of the American Pharmaceutical Association, v. 29, p. 245-249, 1940.

SACCO, J.C. Passifloráceas. In: Flora Ilustrada Catarinense, n. 1. Itajaí, 1980. $131 \mathrm{p}$.

SALAS, M.; WARD, A.; CARO, J. Are proton pump inhibitors the first choice for acute treatment of gastric ulcers? A meta analysis of randomized clinical trials. BMC Gastroenterology, v. 2, p. 17, 2002.

SANTOS, K.C.; SANTOS, C.A.M.; OLIVEIRA, R.M.W. Passiflora actinia Hooker extracts and fractions induce catalepsy in mice. Journal of Ethnopharmacology, $v$. 100, p. 306-309, 2005.

SASS, J.E. Botanical microtechnique. Ames: lowa State College Press, 1951. $391 \mathrm{p}$.

SCAVONE, O.; PANIZZA, S. Aspectos botânicos e medicinais de plantas usadas como tranquilizante, destacando-se as nativas do Brasil. Anais de Farmácia e Química de São Paulo, v. 18, p. 185-197, 1978.

SEIGLER, D.S.; SPENCER, K.C.; STATIER, W.S.; CONN, E.E.; DUNN, J.E. Tetraphyllin B and epitetraphyllin B sulphates: novel cyanogenic glucosides from Passiflora caerulea and $P$. alato-caerulea. Phytochemistry, v. 21, p. 2277-2282, 1982. 
SHI, C.C.; CHEN, S.Y.; WANG, G.J.; LIAO, J.F.; VHEN, C.F. Vasorelaxant effect of harman. European Journal of Pharmacology, v. 390, p. 319-325, 2000.

SILVA, R.A.D. Pharmacopeia dos Estados Unidos do. Brasil. São Paulo: Companhia Editora Nacional, 1929. 237p.

SOULIMANI, R; YOUNOS, C.; JARMOUNI, S.; BOUSTA, D.; MISSLIN, R.; MORTIER, F. Behavioural effects of Passiflora incarnata L. and its indole alkaloid and flavonoid derivatives and maltol in the mouse. Journal of Ethnopharmacology, v. 57, p. 11-20, 1997.

SOUZA, K.C.B.; ORTEGA, G.G. Padronização e estudo preliminar da estabilidade de extratos hidroalcoólicos de Passiflora edulis Sims. (maracujá). Caderno de Farmácia, v. 13, p. 147-148, 1997.

SOUZA, K.C.B. Desenvolvimento de metodologias analíticas e tecnológicas na obtenção de extratos secos nebulizados de Passiflora edulis variedade flavicarpa. Porto Alegre, 1997. Dissertação de Mestrado - Universidade Federal do Rio Grande do Sul.

SOUZA, J.S.I.; MELETTI, L.M.M. Maracujá: espécies, variedades, cultivo. Piracicaba: FEALQ, 1997. 179p.

SPENCER, C.K.; SEIGLER, D.S. Cyanogenesis of Passiflora edulis. Journal of Agricultural and Food Chemistry, v. 31, p. 794-796, 1983.

SPENCER, K.C.; SEIGLER, D.S. Gynocardin from Passiflora. Planta Medica, v. 51, p. 356-357, 1984.

SPENCER, K.C.; SEIGLER, D.S. Passifbiflorin, epipassibiflorin and passitrifasciatin: cyclopentenoid cyanogenic glycosides from Passiflora. Phytochemistry, v. 24, p. 981-986, 1985.

SPENCER, K.C.; SEIGLER, D.S.; NAHRSTEDI, A. Linamarin, lotaustralin, linustatin and neolinustatin from Passiflora species. Phytochemistry, v. 25, p. 645-647, 1986. 
SPERONI, E.; MINGHETTI, A. Neuropharmacological activity of extracts from Passiflora incarnata. Planta Medica, v. 54, n. 6, p. 488-91, 1988.

TREASE, G.E.; EVANS, W.C. Pharmacognosy. 14. ed. London: W.B. Saunders, 1996. 612p.

TRONCHET, J. Flavonic make-up of the aerial organs (mature leaves in the vegetative and floral states, tendrils, perianth) of Passiflora caerulea L. In: Compte Rendu du Congrès National des Sociétés Savantes de Paris, v. 103, p. 225-233, 1978.

ULUBELEN, A.; MABRY, T.J. C-glycosylflavonoids from Passiflora serratifolia. Journal of Natural Products, v. 43, p. 162, 1980.

ULUBELEN, A.; AYYILDIZ, H.; MABRY, T.J. C-glycosylflavonoids and other compounds from Passiflora cyanea, $P$. oerstedii and $P$. menispermifolia. Journal of Natural Products, v. 44, p. 368-369, 1981.

ULUBELEN, A.; OKSUZ, S.; MABRY, T.J. C-glucosylflavonoids from Passiflora pittieri, Passiflora alata, Passiflora ambigua and Adenia mannii. Journal of Natural Products, v. 45, p. 783, 1982.

ULUBELEN, A.; TOPCU, G.; MABRY, T.J.; DELLAMONICA, G.; CHOPIN, J. Cglycosylflavonoids from Passiflora foetida f. hispida and $P$. foetida f. hibiscifolia. Journal of Natural Products, v. 45, p. 103, 1982.

ULUBELEN, A.; KERR, R.R.; MABRY, T.J. Two new neoflavonoids and Cglycosylflavones from Passiflora serratodigitata. Phytochemistry, v. 21, n. 5, p. 1145-1147, 1982.

ULUBELEN, A.; MABRY, T.J. Flavonoids from Passiflora trinervia and $P$. sanguinolenta. Journal of Natural Products, v. 46, p. 597, 1983.

ULUBELEN, A.; MABRY, T.J.; DELLAMONICA, G.; CHOPIN, J. Flavonoids from Passiflora palmeri. Journal of Natural Products, v. 47, p. 384-385, 1984. 
VASCONCELLOS, M.A.S.; CEREDA, E.; BUSQUE, R.N.B.; PACE, C.A.M. Observações sobre a incompatibilidade floral no maracujazeiro doce ( $P$. alata). In: Congresso Brasileiro de Fruticultura, n. 13. Salvador: Sociedade Brasileira de Fruticultura, v. 3, p. 830, 1994.

VEIGA JUNIOR, V.F.; PINTO, A.C.; MACIEL, M.A.M. Plantas medicinais: cura segura? Química Nova, n. 28, p. 519-528, 2005.

WAGNER, H.; BLADT, S. Plant drug analysis: a thin layer chromatography atlas. 2. ed. Berlin: Springer, 1996. 384p.

WORLD HEALTH ORGANIZATION. Quality control methods for medicinal plant materials. Geneva: WHO Library, p. 41-43, 1998.

WOLFMAN, C.; VIOLA, H.; PALADINI, A.; DAJAS, F.; MEDINA, J.H. Possible anxiolytic effects of chrysin, as central benzodiazepine receptor ligand isolated from Passiflora caerulea. Pharmacology Biochemistry and Behavior, v. 47, p. 1-4, 1994.

YAMADA, H.; SUN, X.B.; MATSUMOTO, T.; RA, K.S.; HIRANO, M.; KIYOHARA, H. Purification of anti-ulcer polysaccharides from the roots of Bupleurum falcatum. Planta Medica, v. 57, p. 555-559, 1991.

YAMAMOTO, N.; MOON, J.H.; TSUSHIDA, T.; NAGAO, A.; TERAO, J. Inhibitory effect of quercetin metabolites and their related derivatives on copper ion-induced lipid peroxidation in human low-density lipoprotein. Archives of Biochemistry and Biophysics, v. 372, p. 347-354, 1999.

YOSHIKAWA, M.; MORIKAWA, T.; LI, N.; NAGATOMO, A.; Li, X.; MATSUDA, H. Bioactive saponins and glycosides. XXIII. Triterpene saponins with gastroprotective effect from the seeds of Camellia sinensis-theasaponins E3, E4, E5, E6, and E7. Chemical and Pharmaceutical Bulletin, v. 53, p. 1559-1164, 2005.

ZANOLI, P.; AVALLONE, R.; BARALDI, M. Behavioural characterization of the flavonoids apigenin and chrysin. Fitoterapia, v. 71, p. S117-123, 2000. 